System-Wide Water Resources Program

\title{
Linkage of a Physically Based Distributed Watershed Model and a Dynamic Plant Growth Model
}

Billy E. Johnson and Cade L. Coldren

December 2006 


\section{Linkage of a Physically Based Distributed Watershed Model and a Dynamic Plant Growth Model}

Billy E. Johnson

Environmental Laboratory

U.S. Army Engineer Research and Development Center

3909 Halls Ferry Road

Vicksburg, MS 39180-6199

Cade L. Coldren

Montgomery Watson Harza, Inc.

760 Whalers Way, A-100

Fort Collins, CO 80525

Final report

Approved for public release; distribution is unlimited. 


\begin{abstract}
The impact of hydrological alteration on vegetation and of vegetation on water quality can be greatly facilitated by linking existing water engines with general ecosystem models designed to make long-term projections of ecosystem dynamics. This development effort investigated the linkage of soil moisture between the Gridded Surface Subsurface Hydrologic Analysis (GSSHA) model and the Ecological Dynamics Simulation (EDYS) model. Conceptually, the EDYS and GSSHA models are well-suited for linkage given that they are both designed to simulate physical or ecological processes at multiple spatial and temporal scales. In particular, EDYS computes small-scale flows (precipitation, interception, evaporation, infiltration, transpiration, and nutrient and contaminant uptake) on a daily basis, and can thereby provide much more accurate estimates of evapotranspiration and water, nutrient, and contaminant uptake by vegetation than would ordinarily be available for calibration of hydrologic models. GSSHA and associated groundwater codes can then provide more accurate estimates of large-scale hydrological and transport processes back to EDYS to effect a system-wide assessment or projection. The long-term objective of this linkage between EDYS and GSSHA is to collaborate with other SWWRP product lines and provide a dynamic ecohydro modeling capability for regional applications (i.e., the Upper Mississippi, the Everglades, or the Nueces Basin).
\end{abstract}

DISCLAIMER: The contents of this report are not to be used for advertising, publication, or promotional purposes. Citation of trade names does not constitute an official endorsement or approval of the use of such commercial products. All product names and trademarks cited are the property of their respective owners. The findings of this report are not to be construed as an official Department of the Army position unless so designated by other authorized documents. 


\section{Contents}

Figures and Tables............................................................................................................................................

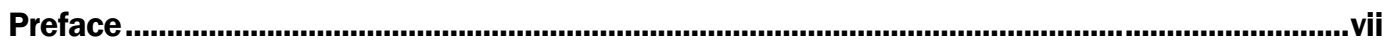

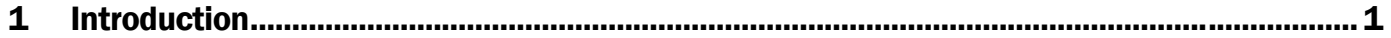

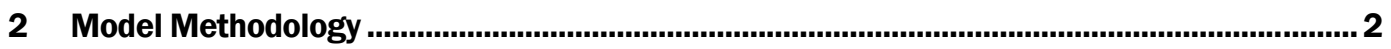

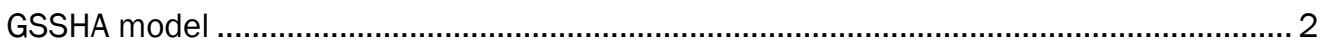

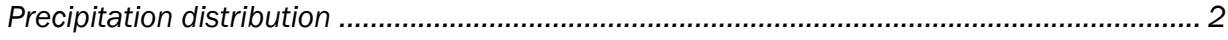

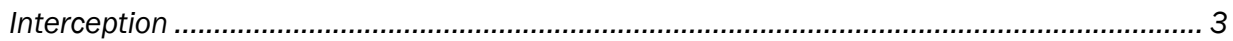

Evaporation and evapotranspiration ............................................................................... 3

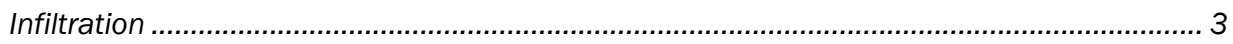

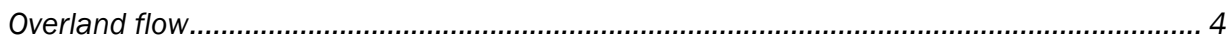

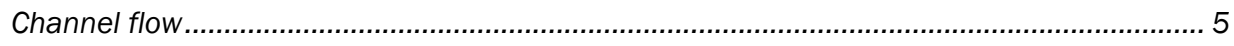

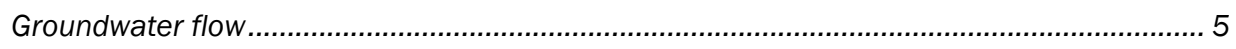

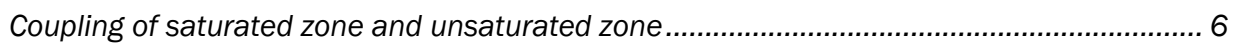

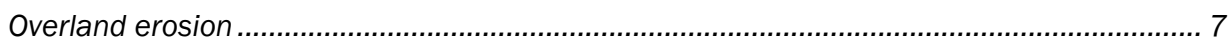

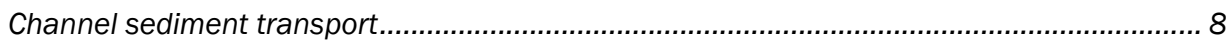

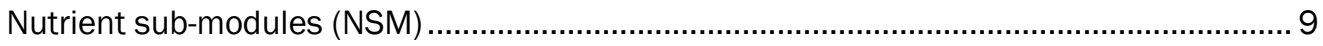

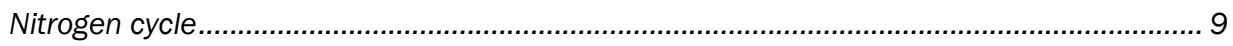

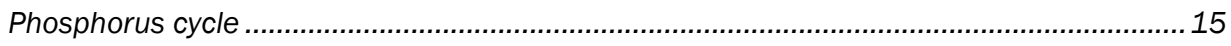

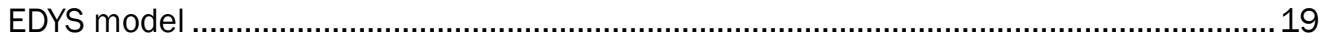

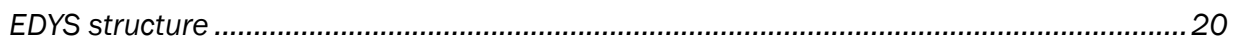

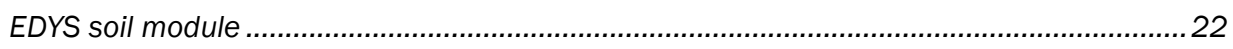

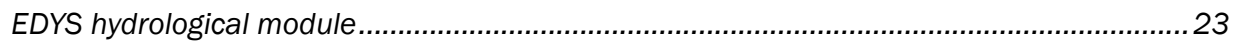

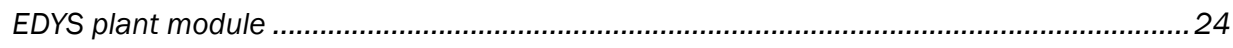

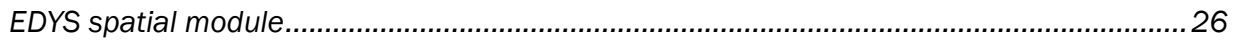

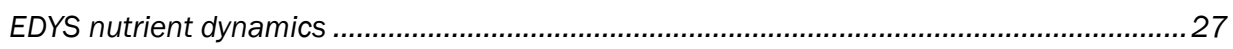

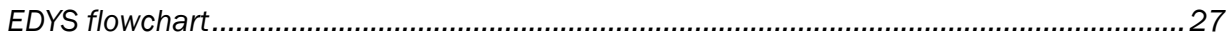

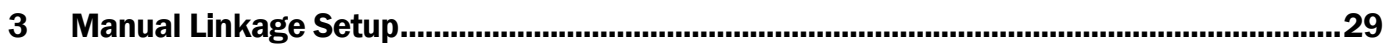

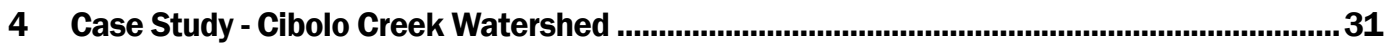

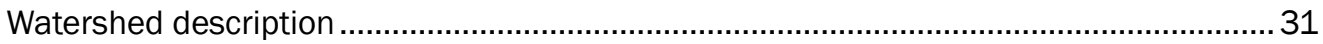

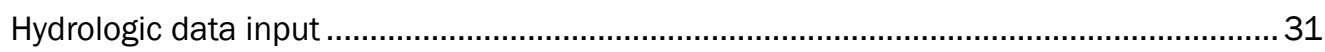

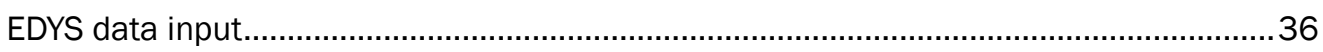

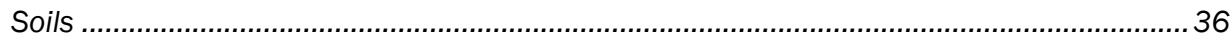

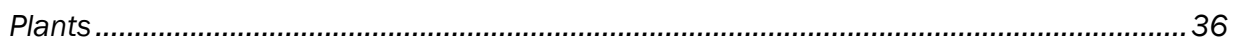

Hydrologic model output ......................................................................................... 42

EDYS model output .......................................................................................... 44

5 Conclusions and Recommendations ..............................................................................46 


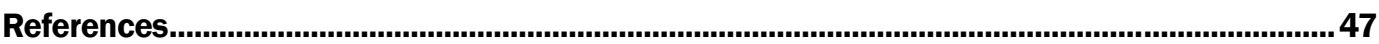

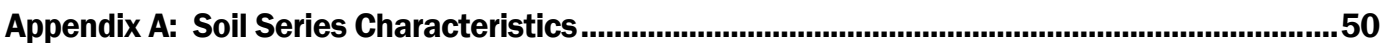

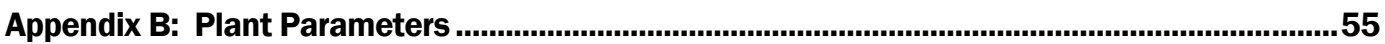

Report Documentation Page 


\section{Figures and Tables}

\section{Figures}

Figure 1. Nitrogen cycle.

Figure 2. Soil nitrogen pools and processes that move nitrogen in and out of pools....................... 11

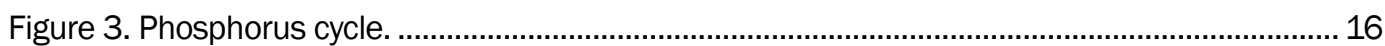

Figure 4. Soil phosphorus pools and processes that move $\mathrm{P}$ in and out of pools........................... 17

Figure 5. Multiple scales represented in EDYS simulations......................................................... 21

Figure 6. Plot-level structure of the EDYS general ecosystem model............................................... 21

Figure 7. Plot-level hydrological dynamics in the EDYS model. .......................................................... 24

Figure 8. Landscape-level hydrology in the EDYS model.................................................................. 25

Figure 9. Plot-level nitrogen dynamics in EDYS. .......................................................................... 27

Figure 10. Simulation flowchart for the EDYS model................................................................ 28

Figure 11. Digitial elevation map (120 m) for Cibolo Creek Watershed. ...........................................32

Figure 12. Soil texture map for Cibolo Creek Watershed ..................................................................32

Figure 13. Land use map for Cibolo Creek Watershed...................................................................33

Figure 14. Rain gage locations (two gages) and stream network. .................................................34

Figure 15. Precipitation depth for Boerne and Bulverde Gages........................................................35

Figure 16. Flow comparison location for Boerne Gage site. ...........................................................35

Figure 17. Flow (cfs) output at Boerne Gage. .......................................................................... 42

Figure 18. Flow (cfs) Output at Selma Gage (Watershed Outlet)....................................................... 43

Figure 19. Surface and channel depths $(\mathrm{m})$ at 8/27/01 0:00........................................................ 43

\section{Tables}

Table 1. Plant parameters used by EDYS to simulate plant dynamics.............................................2

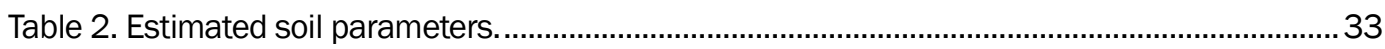

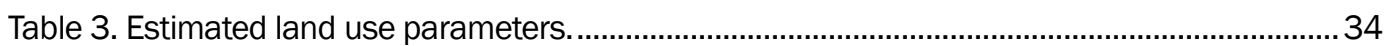

Table 4. Soil series modeled in the EDYS application for Cibolo Creek Watershed............................36

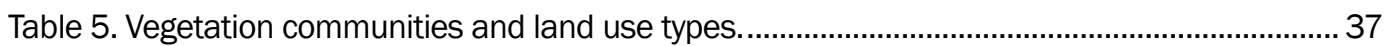

Table 6. Plant species used in the Cibolo Creek EDYS Model. ...........................................................38

Table 7. Initial plant biomasses by plant community and land use type..........................................39

Table 8. Total soil moisture on 1 September $(\mathrm{mm})$..................................................................... 44

Table 9. Total aboveground biomass on 30 September $\left(\mathrm{g} / \mathrm{m}^{2}\right)$. ................................................. 45

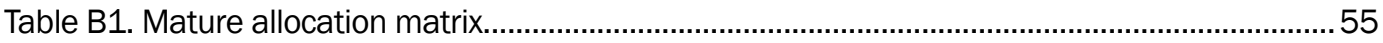

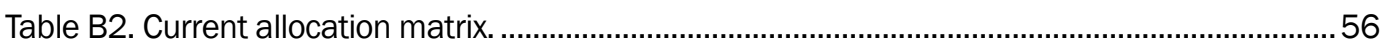

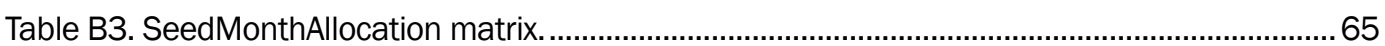

Table B4. GreenOutAllocation matrix. ..................................................................................... 66

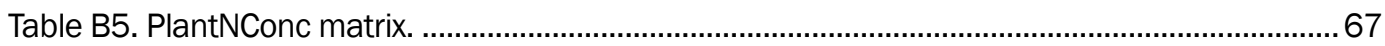




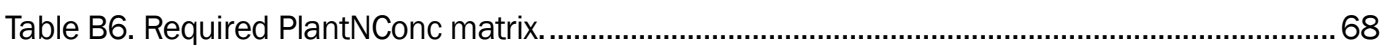

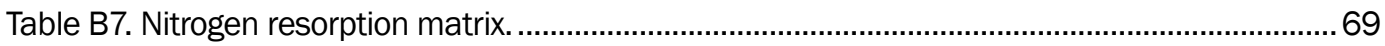

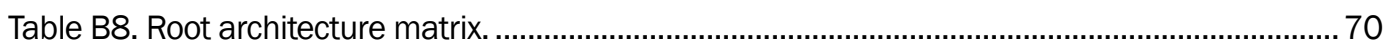

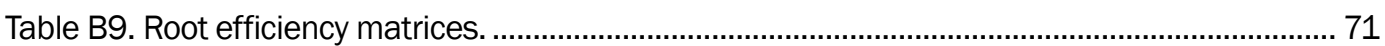

Table B10. Physiological month triggers. ...............................................................................

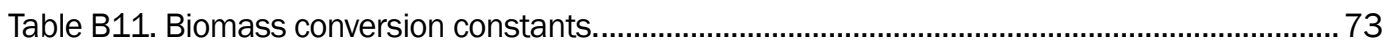

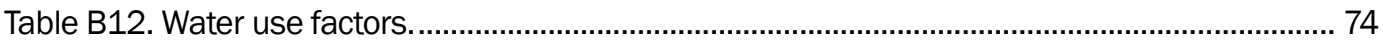

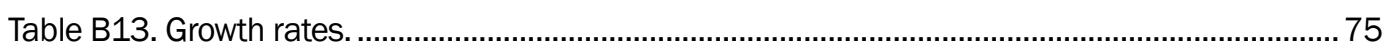

Table B14. Monthly maximum growth rates............................................................................. 76

Table B15. Plant part productivity................................................................................................ 77

Table B16. Green-out plant part productivity............................................................................ 78

Table B17. Light competition factors. ...................................................................................... 79

Table B18. Physiological controls. ........................................................................................ 83

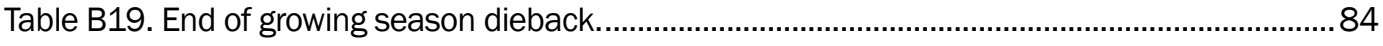

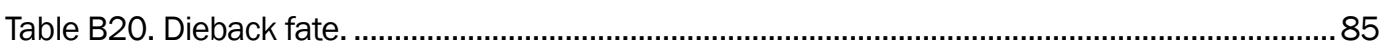

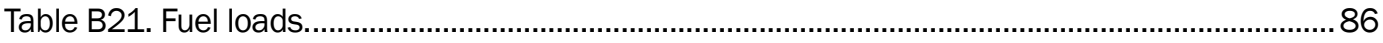

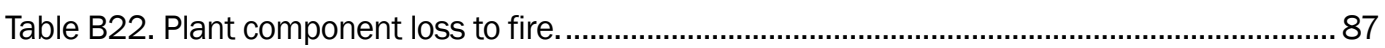

Table B23. Insect preference and competition matrix. ……..................................................... 88

Table B24. Insect accessibility matrix. .................................................................................. 89

Table B25. Rabbit preference and competition matrix. ..............................................................90

Table B26. Rabbit accessibility matrix. ……………….............................................................. 91

Table B27. Deer preference and competition matrix................................................................92

Table B28. Deer accessibility matrix. …………………..................................................................93

Table B29. Cattle preference and competition matrix ...........................................................94

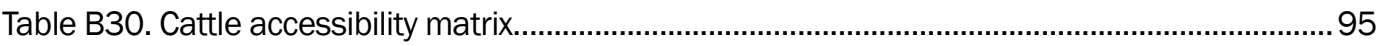




\section{Preface}

This report summarizes the linkage of a physically based distributed watershed model and a dynamic plant growth model. This study was performed by the U.S. Army Engineer Research and Development Center (ERDC), Vicksburg, MS, and Montgomery Watson Harza Global Inc. (MWH) under a Broad Agency Announcement (BAA), BAA FY01 EL-30 Ecological Modeling, entitled "Use of Simulation Modeling to Evaluate Land Management Impact on Watershed Yield in the Lower Edwards Plateau of Texas." Funding was provided under the System-Wide Water Resources Program (SWWRP). Dr. Steven L. Ashby is program manager for SWWRP. Appreciation is extended to all those that provided data for the watershed and plant dynamic simulations.

The Gridded Surface Subsurface Hydrologic Analysis (GSSHA) and the Ecological Dynamic Simulation (EDYS) model were used in this effort. This work was done using data provided for the Cibolo Creek Watershed, located in the vicinity of San Antonio, Texas, by a number of project participants.

Principal Investigators for this study were Dr. Billy E. J ohnson, Water Quality and Contaminant Modeling Branch (WQCMB), Environmental Laboratory (EL), ERDC, and Dr. Cade L. Coldren, Montgomery Watson Harza Global, Inc. Dr. J ohnson conducted his portion of the study under the general supervision of Dr. Barry W. Bunch, Chief, WQCMB, EL, and under the general supervision of Dr. Richard E. Price, Chief, Environmental Processes and Engineering Division (EPED), EL, and Dr. Beth C. Fleming, Director, EL.

COL Richard B. J enkins was Commander and Executive Director of ERDC. Dr. J ames R. Houston was Director. 


\section{Introduction}

The impact of hydrological alteration on vegetation and of vegetation on water quality can be greatly facilitated by linking existing water engines with general ecosystem models designed to make long-term projections of ecosystem dynamics. This development effort initially investigated the linkage of soil moisture between the Gridded Surface Subsurface Hydrologic Analysis (GSSHA) model and the Ecological Dynamics Simulation (EDYS) model. Conceptually, the EDYS and GSSHA models are wellsuited for linkage, given that they are both designed to simulate physical or ecological processes at multiple spatial and temporal scales. In particular, EDYS computes small-scale flows (precipitation, interception, evaporation, infiltration, transpiration, and nutrient and contaminant uptake) on a daily basis, and can thereby provide much more accurate estimates of evapotranspiration and water, nutrient, and contaminant uptake by vegetation than would ordinarily be available for calibration of hydrologic models. GSSHA and associated groundwater codes can then provide more accurate estimates of large-scale hydrological and transport processes back to EDYS to effect a system-wide assessment or projection. The longterm objective of this linkage between EDYS and GSSHA is to collaborate with other System-Wide Water Resources Program (SWWRP) product lines and provide a dynamic eco-hydro modeling capability for regional applications (i.e., the Upper Mississippi, the Everglades, or the Nueces Basin). 


\section{Model Methodology}

This chapter discusses the GSSHA Model (Downer and Ogden 2002), the Nutrient Sub-Models (NSM) (J ohnson 2005), and the EDYS model.

\section{GSSHA model}

This section will discuss the various methodologies found within GSSHA, that encompass the hydrologic cycle, including

- Precipitation distribution

- Interception

- Infiltration

- Evaporation and evapotranspiration

- Overland flow

- Channel flow

- Groundwater flow

- Coupling of saturated zone and unsaturated zone

- Soil erosion and sediment routing.

\section{Precipitation distribution}

Rainfall is a required input within all hydrologic models. Rainfall may be input as spatially and temporally uniform, at a specified rate for a specified duration, for a single event, or rainfall may be input as spatially and temporally varying for any number of rainfall events.

The rainfall interpolation techniques available for spatially varied rainfall are: 1) Inverse Distance Squared Method; or 2) Thiessen Polygon Method. No interpolation method can create information without creating uncertainty. All interpolation methods "estimate" the spatially varied field from point measurements, introducing uncertainty. The Thiessen polygon method is simply a nearest-neighbor approach, while the inverse distance squared method produces smooth fields based on the assumption that the influence of a measured value decreases with the distance from the point of measurement squared.

NEXRAD precipitation estimates can be used in GSSHA, by formatting the data into a GSSHA precipitation file using the RADAR precipitation type 
card. When using NEXRAD rainfall estimates, GSSHA assigns a rain gage at the center of each radar data pixel. When combined with Thiessen polygon rainfall interpolation, this reproduces the original radar pixels.

Inverse-distance squared interpolation should not be used with radar data.

\section{Interception}

The interception of rainfall by vegetation is modeled in GSSHA using the two-parameter method published by Gray (1970). An initial quantity of rainfall ( $\mathrm{mm}$ ) entirely intercepted by foliage and a storage capacity are specified within the model for each land-use type.

\section{Evaporation and evapotranspiration}

The evaporation and evapo-transpiration models incorporated in GSSHA allow calculation of the loss of soil water to the atmosphere, improving the determination of soil moistures. Two different evapo-transpiration options are included:

- Bare-ground evaporation from the land-surface using the formulation suggested by Deardorff (1978)

- Evapo-transpiration from a vegetated land-surface utilizing the Penman-Monteith equation (Monteith 1965, 1981).

Variants of these two representations are widely used in land-surface schemes of climate and distributed hydrologic models (e.g., Dickinson et al. 1986; Beven 1979).

\section{Infiltration}

Water ponded on overland flow plane cells will infiltrate into the soil as conditions permit. Infiltration is dependent upon soil hydraulic properties and antecedent moisture conditions, which may be affected by previous rainfall, run-on, ET, and the location of the water table. In GSSHA, the unsaturated zone that controls infiltration may be simulated with a onedimensional (1-D) formulation of Richards' equation (RE), which simulates infiltration, ET, and soil moisture movement in an integrated fashion. Infiltration may also be simulated using traditional Hortonian Green and Ampt (GA) (Green and Ampt 1911) approaches, which are simplifications of RE. There are three optional GA-based methods to calculate infiltration for Hortonian basins: 1) traditional GA infiltration, 
2) multi-layer GA, and 3) Green and Ampt infiltration with redistribution (GAR) (Ogden and Saghafian 1997). The traditional GA and multi-layer GA approaches are used for single event rainfall when there are no significant periods of rainfall hiatus. The GAR approach is used when there are significant breaks in the rainfall, or for continuous simulations.

$\mathrm{RE}$ is a general equation and can be applied in any type of watershed or conditions. However, the simpler methods based on the GA equation are preferred when runoff is Hortonian, i.e. occurs due to infiltration excess, where the rainfall/run-on of water is greater than the possible infiltration rate. For fine-textured soils the GAR method has been shown to closely mimic the RE solution (Ogden and Saghafian 1997) and when applied in basins identified as Hortonian, the GAR method has been shown to produce results comparable with the RE (Downer and Ogden 2003a).

However, when Hortonian flow is not the predominant mechanism producing stream flow, application of GA type models is ill advised and can result in erroneous results (Downer and Ogden 2002). For cases where Hortonian flow is not the predominant process generating stream flow, the RE should be used and coupled with the saturated groundwater solution as appropriate. Representation of the soil column below each cell with Richards' equation is presented.

\section{Overland flow}

Overland flow in GSSHA employs the diffusive wave approximation in two dimensions ( $\mathrm{x}$ and $\mathrm{y}$ ). Flow is routed in two orthogonal directions in each grid cell during each time-step. The watershed boundary represents a noflow boundary for the overland flow routing and when a grid cell lies on the watershed boundary, flow is not routed across the boundary. In GSSHA, $\Delta x=\Delta y$. Inter-cell fluxes in the $x$ and $y$ directions ( $p$ and $q$, respectively) are computed in cell $i j$ from the depth $d_{i j}$ at the $n^{\text {th }}$ time level using the Manning equation for the head discharge relationship in the $x$ and y directions. Once water enters a "channel" grid cell, the volume of water is added to the channel system and routed to the watershed outlet. The overland flow routine does allow for depression storage, thus water can pool in a depression until it is able to either build up enough head to overcome the topography, infiltrate into the ground, or evaporate into the air. 


\section{Channel flow}

GSSHA solves the diffusive wave equation using two-step explicit finite volume schemes to route water for both 1-D channels and twodimensional (2-D) overland flow, where flows are computed based on heads, and volumes are updated based on the computed flows. Compared with more sophisticated implicit finite difference and finite element schemes, the algorithm used in GSSHA is simple. The friction slope between one grid cell and its neighbors is calculated as the difference in water surface elevations divided by the grid size. Compared with the kinematic wave approach, this diffusive wave approach allows GSSHA to route water through pits or depressions, and regions of adverse slope. The Manning formula is used to relate flow depth to discharge. Use of the Manning formula implies that the flow is turbulent and that the roughness is not dependent on flow depth. Neither of these assumptions may be valid on the overland flow plane. While being simple, the method is powerful because it allows calculations to proceed when only portions of the stream network or watershed are flowing. This is an important attribute, as rainfall may occur on only a portion of the watershed.

The channel routing scheme was developed to allow water to remain in the channel after channel routing ends, and for water to be present in the channel when channel routing begins. Because groundwater may discharge to the stream at any time, channel routing is initiated any time a minimum amount of water is in the channel network. If the channel routing scheme indicates there is no flow in the channel, channel routing is halted during periods outside precipitation events. Fluxes between the stream and the groundwater are still computed and adjustments to the stream volumes are made without routing. If groundwater discharges to the stream, channel routing will resume, but at the groundwater time-step, which is typically larger than the channel routing time-step.

\section{Groundwater flow}

Trescott and Larson (1977) described the solution to the two-dimensional free surface groundwater problem, and the efficiency of various solvers. Their methods were largely followed in the development of this portion of the code; exhaustive coverage need not be presented here.

The controlling equation, as developed by Pinder and Bredehoeft (1968), is: 


$$
\frac{\partial}{\partial x}\left(T_{x x} \frac{\partial h}{\partial x}\right)+\frac{\partial}{\partial x}\left(T_{x y} \frac{\partial h}{\partial y}\right)+\frac{\partial}{\partial y}\left(T_{y x} \frac{\partial h}{\partial x}\right)+\frac{\partial}{\partial y}\left(T_{y y} \frac{\partial h}{\partial y}\right)=S \frac{\partial h}{\partial t}+W(x, y, t)
$$

where $\mathrm{T}$ is the transmissivity $\left(\mathrm{m}^{2} \mathrm{~s}^{-1}\right)$, $\mathrm{h}$ is the hydraulic head $(\mathrm{m}), \mathrm{S}$ is the storage term (dimensionless), and $\mathrm{W}$ is the flux term for sources and sinks $\left(\mathrm{m} \mathrm{s}^{-1}\right)$.

It is assumed that off-diagonal terms are not important and that transmissivity can be expressed as the product of the saturated hydraulic conductivity of the media (K) and the depth of the saturated media (b). For the free surface problem, the head is the surface water elevation $\left(\mathrm{E}_{\mathrm{ws}}\right)$.

$$
\frac{\partial}{\partial x}\left(K_{x x} b \frac{\partial E_{w s}}{\partial x}\right)+\frac{\partial}{\partial y}\left(K_{y y} b \frac{\partial E_{w s}}{\partial y}\right)=S \frac{\partial E_{w s}}{\partial t}+W(x, y, t)
$$

The equation is solved by successive overrelaxation by lines (LSOR) (for example Tannehill et al. (1997)). LSOR was shown by Trescott and Larson (1977) to be capable of solving a variety of difficult groundwater problems, though not necessarily being the most efficient method. With LSOR, the $2-\mathrm{D}$ problem is linearized by solving by rows or by columns. The user specifies solution by rows or by columns and the choice is made to align the direction of solution with the principal direction of flow, $\mathrm{x}$ (argument 1) or y (argument - 2) (Trescott and Larsen 1977).

\section{Coupling of saturated zone and unsaturated zone}

In GSSHA, the saturated and unsaturated zones are linked through boundary conditions. When saturated groundwater is simulated, the lower boundary of the unsaturated zone is the saturated groundwater surface. Movement of the saturated groundwater surface according to the solution of the 2-D saturated flow equations requires a flexible spatial discretization for Richards' equation. In extreme cases the groundwater table may rise to the soil surface. In this case the unsaturated zone disappears, and only the saturated flow equations are solved.

When heads from the 2-D unconfined groundwater problem solution are used as the lower boundary condition of the unsaturated groundwater problem, the size of the unsaturated zone in each overland flow cell changes with each saturated groundwater update. Also, the storage term used in the saturated groundwater solution does not account for the water 
in the unsaturated zone. After solution of the saturated zone, an extra step is required to account for the water that exists in the unsaturated zone.

Water is exchanged between the saturated and unsaturated zones through fluxes. Fluxes from the saturated zone to the unsaturated zone are added to the source term of the $\mathrm{N}-1$ unsaturated cell during the next update for the unsaturated zone. The same procedure is used for fluxes to the saturated zone from the unsaturated zone. The formulation of the RE is exploited to correct any temporarily incorrect values of soil moisture or groundwater head. While this method works, it may induce a time lag in the solution.

The simple "bucket" soil moisture accounting routine is used to calculate soil moistures between rainfall events. Soil moisture accounting begins at the end of the rainfall event, when the outlet discharge falls below the event minimum Q. At that time the soil moistures provided by the GAR method are sent to the soil moisture accounting routine and soil moisture calculations proceed until the next specified rainfall event. In the soil moisture accounting routine, the soil moisture is adjusted hourly for losses due to ET only. Even though water may be present on the overland flow plane, flowing and infiltrating, this does not affect the soil moisture accounting calculations. In this respect there is a disconnect between the ET calculations and the infiltration calculations. The storage term used in the saturated groundwater calculations in each cell is assumed to be the effective porosity of the cell minus the initial moisture. The initial moisture is updated at the beginning of each rainfall event. When the groundwater elevations exceed the ground surface elevation, infiltration calculations for the cell cease, and the groundwater surface exchange is calculated as described above. Any time exfiltration occurs, the infiltration and overland flow processes are initiated if they are not already active. These processes remain active as long as exfiltration occurs and until all water on the overland flow plane stops flowing and infiltrating. Infiltration is not calculated for cells in which exfiltration is occurring.

\section{Overland erosion}

In order to estimate overland erosion, GSSHA employs an equation based on the work of Kilinc and Richardson (1973). Kilinc and Richardson studied the mechanics of overland soil erosion in at Colorado State University Engineering Research Center in a flume that is $1.2 \mathrm{~m}$ deep, 
$1.5 \mathrm{~m}$ wide, and $4.9 \mathrm{~m}$ in length. Their investigation resulted in a sediment transport equation of uniform flow sheet and rill erosion on bare sandy soil. J ulien et al. (1995) modified the original Kilinc-Richardson equation to expand the applicability of the equation to non-uniform flow with consideration of factors specific to soil and land use (i.e., Universal Soil Loss Equation (USLE) factors, K, C, and P). The K, C, and P factors are empirical coefficients with the same conceptual meaning as those used in the USLE (Renard et al. 1991).

The surface of each grid cell is either eroded or aggraded depending upon the quantity of sediment in suspension and the potential sediment transport rates. This determination is made for three grain sizes (sand, silt, and clay). Conservation of mass of sediment determines how much sediment entering each grid cell stays in suspension, and how much is deposited. The sediment transport capacity is satisfied by sediments already in suspension, previously deposited sediments, and then sediments in the parent material, respectively. If sediments in suspension are unable to satisfy the potential transport rate, the previously deposited sediment is used to satisfy the demand. If there is insufficient previous deposition, then the surface is eroded to meet the demand. If the potential sediment transport rates calculated are insufficient to transport the sediment already in suspension within a grid cell, sediment is deposited on the surface (J ohnson 1997).

\section{Channel sediment transport}

The present version of GSSHA employs Yang's (1973) unit stream power method for routing sand-size total load in stream channels. Unit stream power is defined as the product of the average flow velocity $U$ and the channel slope $\mathrm{S}_{\mathrm{o}}$. The rate of work done per unit weight of water in transporting sediment is assumed directly related to the rate of work available per unit weight of water. Thus, the total sediment concentration or total bed-material load must be directly related to the unit stream power.

The routing formulation for sand-size sediments is limited to trapezoidal channels with a user-specified maximum allowable depth of degradation in the channel. The channel bed is assumed to be mobile, and the banks are fixed. Degradation continues and bed load is transported at the rate calculated with the Yang (1973) method until the maximum degradation is reached. During degradation, the initial bed width is maintained and 
degradation is uniform across the width of the bed. If the channel aggrades, the trapezoidal cross-section is filled. If a channel link has aggraded, and then degrades, the degradation will occur uniformly over the bottom of the trapezoid until the original bed elevation is restored. Further degradation occurs vertically downward from the initial trapezoid bottom width. If a channel degraded below the original bed elevation begins to aggrade, sediment will accumulate uniformly in the rectangular degraded area below the original bed elevation. Once the bed aggrades beyond the original bed elevation, the entire width of the trapezoid is filled.

In the channels, silt and clay size particles are assumed to be in suspension, and are transported as wash load. This treatment implies that the flow is turbulent, and the travel time to the outlet of the catchment is short compared to the settling time, such that particles do not settle in the channel network. This assumption, combined with no bank erosion, results in the channels being neither a source nor sink of fines. Routing of suspended fines is a natural extension of the explicit diffusive-wave channel routing method. Suspended fine sediments are routed as concentrations. The concentration changes as a function of gradients in both concentration and velocity.

\section{Nutrient sub-modules (NSM)}

The current SWWRP-NSM nutrient formulations, nitrogen and phosphorus, have been taken primarily from the SWAT model formulation. SWAT models the fate of the nutrients on a distributed scale.

\section{Nitrogen cycle}

The three major forms of nitrogen in mineral soils are: 1) organic nitrogen associated with humus, 2) mineral forms of nitrogen held by soil colloids, and 3) mineral forms of nitrogen in solution.

Nitrogen may be added to the soil by fertilizer, manure or residue application, fixation by symbiotic or nonsymbiotic bacteria, and rain. Nitrogen is removed from the soil by plant uptake, leaching, volatilization, denitrification, and erosion. Figure 1 shows the major components of the nitrogen cycle. 


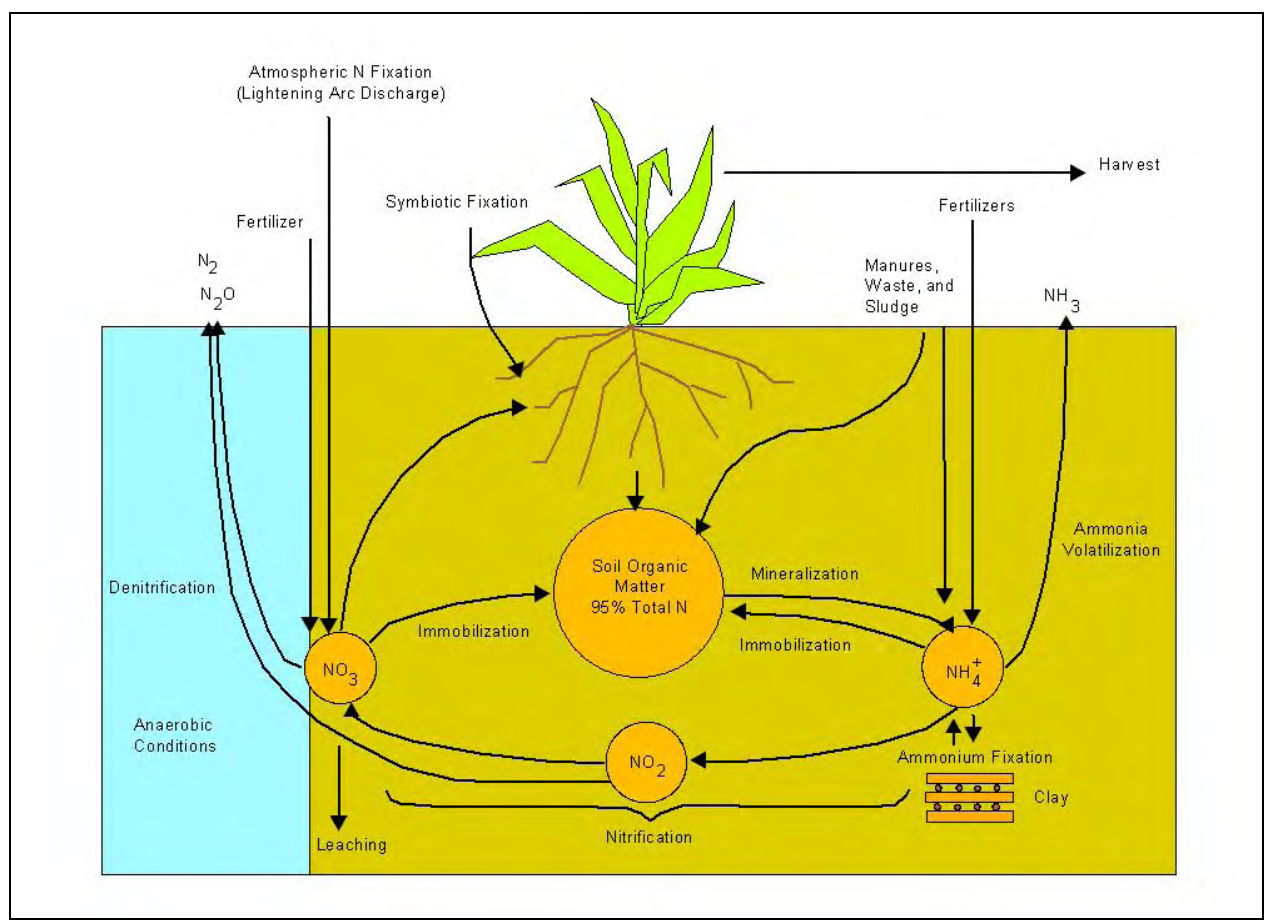

Figure 1. Nitrogen cycle.

Nitrogen is considered to be an extremely reactive element. The highly reactive nature of nitrogen results from its ability to exist in a number of valence states. The valance state or oxidation state describes the number of electrons orbiting the nucleus of the nitrogen atom relative to the number present in an electronically neutral atom. The valence state will be positive as the atom loses electrons and will be negative as the atom gains electrons.

The ability of nitrogen to vary its valence makes it a highly mobile element. Predicting the movement of nitrogen between the different pools in the soil is critical to the successful management of this element in the environment. Five different pools of nitrogen in the soil are shown in Figure 2.

Two pools are inorganic forms of nitrogen, $\mathrm{NH}_{4}^{+}$and $\mathrm{NO}_{3}^{-}$, while the other three pools are organic forms of nitrogen. Fresh organic $\mathrm{N}$ is associated with crop residue and microbial biomass, while the active and stable organic $\mathrm{N}$ pools are associated with the soil humus. The organic nitrogen associated with humus is partitioned into two pools to account for the variation in availability of humic substances to mineralization. 


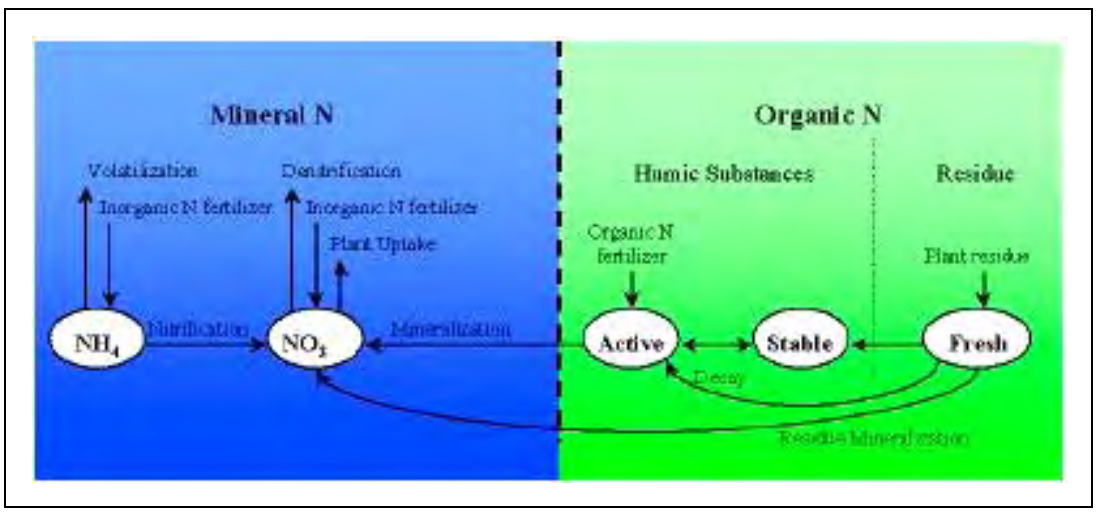

Figure 2. Soil nitrogen pools and processes that move nitrogen in and out of pools.

Mineralization, decomposition, and immobilization

Decomposition is the breakdown of fresh organic residue into simpler organic components. Mineralization is the microbial conversion of organic, plant-unavailable nitrogen to inorganic, plant-available nitrogen. Immobilization is the microbial conversion of plant-available inorganic soil nitrogen to plant-unavailable organic nitrogen.

Bacteria decompose organic material to obtain energy for growth processes. Plant residue is broken down into glucose, which is then converted to energy:

$$
\mathrm{C}_{6} \mathrm{H}_{12} \mathrm{O}_{6}+\mathrm{O}_{2} \stackrel{\text { energyreleased }}{\longrightarrow} 6 \mathrm{CO}_{2}+6 \mathrm{H}_{2} \mathrm{O}
$$

The energy released by the conversion of glucose to carbon dioxide and water is used for various cell processes, including protein synthesis. Protein synthesis requires nitrogen. If the residue from which the glucose is obtained contains enough nitrogen, the bacteria will use nitrogen from the organic material to meet the demand for protein synthesis. If the nitrogen content of the residue is too low to meet the bacterial demand for nitrogen, the bacteria will use ammonium and nitrate from the soil solution to meet its needs. If the nitrogen content of the residue exceeds the bacterial demand for nitrogen, the bacteria will release the excess nitrogen into the soil solution as ammonium. General relationships between the C:N ratio and mineralization/immobilization are:

C:N > 30:1 Immobilization occurs, a net decrease in soil ammonia and nitrate. 
20:1<=C:N <=30:1 Expect no net change; immobilization and mineralization processes are at equilibrium.

C:N < 20:1 Mineralization occurs, a net gain in soil ammonia and nitrate.

Humus mineralization

Nitrogen is allowed to move between the active and stable organic pools in the humus fraction. The amount of nitrogen transferred from one pool to the other is calculated as a function of a rate constant, amount of nitrogen in the active organic pool, fraction of humic nitrogen in the active organic pool, and the amount of nitrogen in the stable organic pool.

When the amount of nitrogen to be transferred is positive, nitrogen is moving from the active organic pool to the stable organic pool. When the amount of nitrogen to be transferred is negative, nitrogen is moving from the stable organic pool to the active organic pool.

Mineralization from the humic active organic $\mathrm{N}$ pool is calculated as a function of a rate constant for mineralization of the humus active organic nutrients, the nutrient cycling temperature factor, the nutrient cycling water factor, and the amount of nitrogen in the active organic pool. Nitrogen mineralized from the humus active organic pool is added to the nitrate pool in the layer.

\section{Residue decomposition and mineralization}

Decomposition and mineralization of the fresh organic nitrogen pool will be allowed only in the first soil layer. Decomposition and mineralization are controlled by a decay rate constant that is updated daily. The decay rate constant is calculated as a function of the $\mathrm{C}: \mathrm{N}$ ratio and the $\mathrm{C}: \mathrm{P}$ ratio of the residue, temperature, and soil water content.

The decay rate constant defines the fraction of residue that is decomposed and is a function of the rate constant for mineralization of the residue fresh organic nutrients, the nutrient cycling residue composition factor, the nutrient cycling temperature factor, and the nutrient cycling water factor. The nutrient cycling residue composition factor is a factor of the $\mathrm{C}: \mathrm{N}$ ratio of the residue in the soil layer and the $\mathrm{C}: \mathrm{P}$ ratio of the residue in the soil layer. Mineralization from the residue fresh organic $\mathrm{N}$ is a function 
of the residue decay rate constant and the nitrogen in the fresh organic pool. Nitrogen mineralized from the fresh organic pool will be added to the nitrate pool in the layer. Decomposition from the residue fresh organic $\mathrm{N}$ pool is a function of the residue decay rate constant and the nitrogen in the fresh organic pool.

Nitrification and ammonia volatilization

Nitrification is a two-step bacterial oxidation of $\mathrm{NO}_{4}^{+}$and $\mathrm{NO}_{3}^{-}$:

Step 1: $\quad 2 \mathrm{NH}_{4}^{+}+3 \mathrm{O}_{2}-\frac{-12 e^{-}}{\rightarrow} 2 \mathrm{NO}_{2}^{-}+2 \mathrm{H}_{2} \mathrm{O}+4 \mathrm{H}^{+} \quad$ (Nitrosomonas)

Step 2: $\quad 2 \mathrm{NO}_{2}^{-}+\mathrm{O}_{2}-\stackrel{-4 e^{-}}{\rightarrow} 2 \mathrm{NO}_{3}^{-} \quad$ (Nitrobacter)

Ammonia volatilization is the gaseous loss of $\mathrm{NH}_{3}$ that occurs when ammonium is surface applied to a calcareous soil or when urea, $\left(\mathrm{NH}_{2}\right)_{2} \mathrm{CO}$, is surface applied to any soil.

Ammonium surface applied to a calcareous soil:

Step 1: $\mathrm{CaCO}_{3}+2 \mathrm{NH}_{4}^{+} \mathrm{X} \leftarrow\left(\mathrm{NH}_{4}\right)_{2} \mathrm{CO}_{3}+\mathrm{CaX}_{2}$

Step 2: $\quad\left(\mathrm{NH}_{4}\right) \mathrm{CO}_{3} \longleftrightarrow 2 \mathrm{NH}_{3}+\mathrm{CO}_{2}+\mathrm{H}_{2} \mathrm{O}$

Urea surface applied to any soil:

Step 1: $\quad\left(\mathrm{NH}_{2}\right)_{2} \mathrm{CO}+2 \mathrm{H}_{2} \mathrm{O} \leftarrow \stackrel{\text { ureaseenzyme }}{\longrightarrow} \rightarrow\left(\mathrm{NH}_{4}\right)_{2} \mathrm{CO}_{3}$

Step 2: $\quad\left(\mathrm{NH}_{4}\right)_{2} \mathrm{CO}_{3} \longleftarrow \rightarrow 2 \mathrm{NH}_{3}+\mathrm{CO}_{2}+\mathrm{H}_{2} \mathrm{O}$

Within the formulation, nitrification and ammonia volatilization will be simulated using a combination of methods developed by Reddy et al. (1979) and Godwin et al. (1984). The total amount of nitrification and ammonia volatilization will be calculated, and then partitioned between the two processes. Nitrification is a function of soil temperature and soil water content, while ammonia volatilization is a function of soil temperature and depth. Three coefficients will be used in the nitrification/ volatilization algorithms to account for the impact of these parameters. It 
will be assumed that nitrification/volatilization occurs only when the temperature of the soil layer exceeds $5^{\circ} \mathrm{C}$.

The nitrification/volatilization temperature factor is a function of the soil temperature. The nitrification soil water factor is a function of the soil water content, the amount of water held in the soil layer at wilting point content, and the amount of water held in the soil layer at field capacity water content. The volatilization depth factor is a function of the depth from the soil surface to the middle of the layer. The impact of environmental factors on nitrification and ammonia volatilization, in a given layer, is defined by the nitrification regulator and volatilization regulator. The nitrification regulator is a factor of the nitrification/volatilization temperature factor and the nitrification soil water factor. The volatilization regulator is a function of the nitrification/volatilization temperature factor and the volatilization depth factor. The total amount of ammonium lost to nitrification and volatilization is calculated using a first-order kinetic rate equation (Reddy et al. 1979), which is a function of the amount of ammonia, the nitrification regulator, and the volatilization regulator. To partition nitrogen between nitrification and volatilization, the expression by which ammonia is multiplied is solved using each regulator individually to obtain a fraction of ammonium removed by each process. The amount of nitrogen removed from the ammonium pool by nitrification and volatilization is thus a function of these computed fractions.

\section{Denitrification}

Denitrification is the bacterial reduction of nitrate, $N_{3}^{-}$, to $\mathrm{N}_{2}$ or $\mathrm{N}_{2} \mathrm{O}$ gases under anaerobic (reduced) conditions. Denitrification is a function of water content, temperature, presence of a carbon source, and nitrate.

In general, when the water-filled porosity is greater than 60 percent, denitrification will be observed in a soil. As soil water content increases, anaerobic conditions develop due to the fact that oxygen diffuses through water 10,000 times slower than through air. Because the rate of oxygen diffusion through water slows as the water temperature increases, temperature will also influence denitrification.

In this formulation, the amount of nitrate lost to denitrification is a function of the amount of nitrate, the nutrient cycling temperature factor, and the amount of organic carbon. 


\section{Nitrogen in rainfall}

Lightning discharge converts atmospheric $\mathrm{N}_{2}$ to nitric acid, which can then be transferred to the soil with precipitation. The chemical steps involved are:

Step 1: $\mathrm{N}_{2}+\mathrm{O}_{2}-\stackrel{\text { arc of electricity }}{\longrightarrow} \rightarrow 2 \mathrm{NO} \quad$ (monoxide)

Step 2: $2 \mathrm{NO}+\mathrm{O}_{2} \longrightarrow \mathrm{NO}_{2} \quad$ (dioxide)

Step 3: $3 \mathrm{NO}_{2}+\mathrm{H}_{2} \mathrm{O} \longrightarrow 2 \mathrm{HNO}_{2}+\mathrm{NO} \quad$ (nitric acid and monoxide)

More nitrogen will be added to the soil with rainfall in areas with a high amount of lightning activity than in areas with little lightning.

The amount of nitrate added to the soil in rainfall is a function of the concentration of nitrogen in the rain and the amount of precipitation on a given day. The nitrogen in rainfall is added to the nitrate pool in the top $10 \mathrm{~mm}$ of soil.

\section{Phosphorus cycle}

Although plant phosphorus demand is considerably less than nitrogen demand, phosphorus is required for many essential functions. The most important of these is its role in energy storage and transfer. Energy obtained from photosynthesis and metabolism of carbohydrates is stored in phosphorus compounds for later use in growth and reproductive processes.

The three major forms of phosphorus in mineral soils are organic phosphorus associated with humus, insoluble forms of mineral phosphorus, and plant-available phosphorus in soil solution. Phosphorus may be added to the soil by fertilizer, manure, or residue application. Phosphorus is removed from the soil by plant uptake and erosion. Figure 3 shows the major components of the phosphorus cycle. 


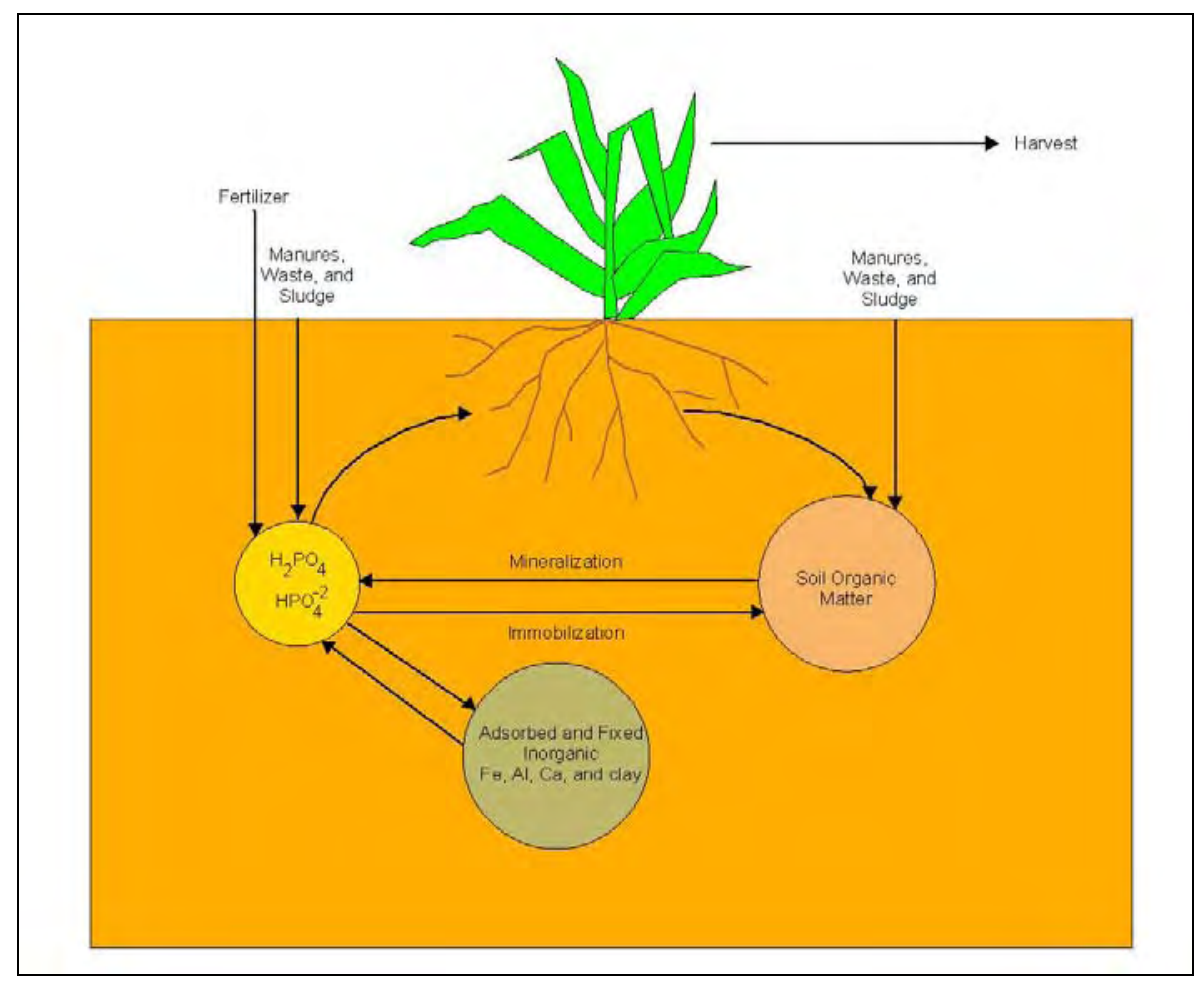

Figure 3. Phosphorus cycle.

Unlike nitrogen, which is highly mobile, phosphorus solubility is limited in most environments. Phosphorus combines with other ions to form a number of insoluble compounds that precipitate out of solution. These characteristics contribute to a buildup of phosphorus near the soil surface that is readily available for transport in surface runoff. In addition to precipitating, phosphorus adsorbs to soil solids and can be transported via soil erosion. Sharpley and Syers (1979) observed that surface runoff is the primary mechanism by which phosphorus is exported from most catchments. Six different pools of phosphorus are represented in the formulation (Figure 4).

Three pools are inorganic forms of phosphorus, while the other three pools are organic forms of phosphorus. Fresh organic $\mathrm{P}$ is associated with crop residue and microbial biomass, while the active and stable organic $P$ pools are associated with the soil humus. The organic $\mathrm{P}$ associated with humus is partitioned into two pools to account for the variation in availability of humic substances to mineralization. Soil inorganic $\mathrm{P}$ is divided into solution, active, and stable pools. The solution pool is in rapid equilibrium (several days or weeks) with the active pool. The active pool is in slow equilibrium with the stable pool. 


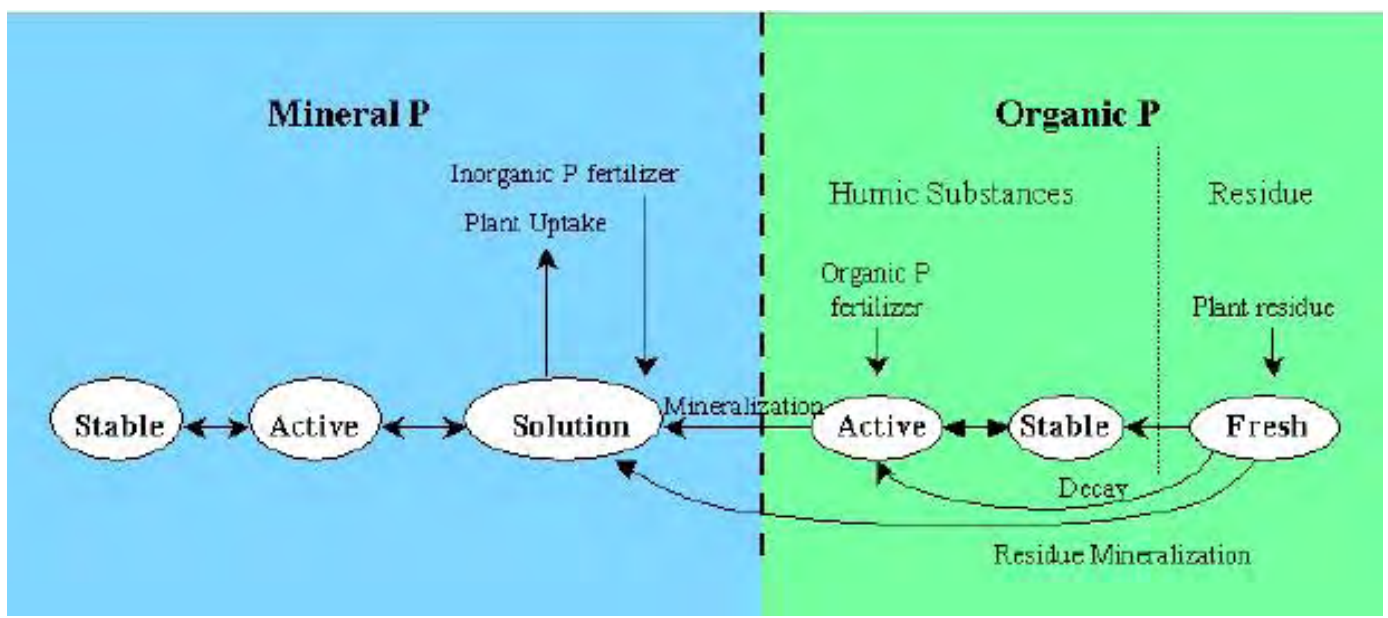

Figure 4. Soil phosphorus pools and processes that move $\mathrm{P}$ in and out of pools.

Mineralization, decomposition, and immobilization

The phosphorus mineralization algorithms within this formulation are net mineralization algorithms which incorporate immobilization into the equations. The phosphorus mineralization algorithms developed by J ones et al. (1984) are similar in structure to the nitrogen mineralization algorithms. Two sources are considered for mineralization: 1) the fresh organic P pool associated with crop residue and microbial biomass; and 2) the active organic $\mathrm{P}$ pool associated with soil humus. Mineralization and decomposition are allowed to occur only if the temperature of the soil layer is above $0{ }^{\circ} \mathrm{C}$.

Mineralization and decomposition are dependent on water availability and temperature. Two factors are used in the mineralization and decomposition equations to account for the impact of temperature and water on these processes.

Humus mineralization

Phosphorus in the humus fraction is partitioned between the active and stable organic pools using the ratio of humus active organic $\mathrm{N}$ to stable organic $\mathrm{N}$. The amount of phosphorus in the active and stable organic pools is a function of the amount of humic phosphorus, the amount of nitrogen in the active organic pool, and the amount of nitrogen in the stable organic pool. Mineralization from the humus active organic $P$ pool is a function of the rate coefficient for mineralization of the humus active organic nutrients, the nutrient cycling temperature factor, the nutrient cycling water factor, and the amount of phosphorus in the active organic 
pool. Phosphorus mineralized from the humus active organic pool is added to the solution $\mathrm{P}$ pool.

\section{Residue decomposition and mineralization}

Decomposition and mineralization of the fresh organic phosphorus pool is allowed only in the first soil layer. Decomposition and mineralization are controlled by a decay rate constant that is continuously updated.

\section{Sorption of inorganic $P$}

Many studies have shown that after an application of soluble P fertilizer, solution $\mathrm{P}$ concentration decreases rapidly with time due to reaction with the soil. This initial "fast" reaction is followed by a much slower decrease in solution P that may continue for several years (Barrow and Shaw 1975; Munns and Fox 1976, Rajan and Fox 1972, Sharpley 1982). In order to account for the initial rapid decrease in solution $\mathrm{P}$, this formulation assumes that a rapid equilibrium exists between solution $\mathrm{P}$ and an "active" mineral pool. The subsequent slow reaction is simulated by the slow equilibrium assumed to exist between the "active" and "stable" mineral pools. The algorithms governing movement of inorganic phosphorus between these pools are taken from J ones et al. (1984).

Equilibrium between the solution and active mineral pool is governed by the phosphorus availability index. This index specifies the fraction of fertilizer $\mathrm{P}$ that is in solution after an incubation period, i.e., after the rapid reaction period.

The movement of phosphorus between the solution and active mineral pools will be governed by the equilibrium equations, which are a function of the amount of phosphorus in the active mineral pool, the amount of phosphorus in solution, and the phosphorus availability index. When the phosphorus amount is positive, phosphorus is being transferred from solution to the active mineral pool. When the phosphorus amount is negative, phosphorus is being transferred from the active mineral pool to solution. Note that the rate of flow from the active mineral pool to solution is one tenth the rate of flow from solution to the active mineral pool.

This formulation simulates slow phosphorus sorption by assuming the active mineral phosphorus pool is in slow equilibrium with the stable 
mineral phosphorus pool. At equilibrium, the stable mineral pool is four times the size of the active mineral pool.

When not in equilibrium, the movement of phosphorus between the active and stable mineral pools is a function of the slow equilibrium rate constant, the amount of phosphorus in the active mineral pool, and the amount of phosphorus in the stable mineral pool.

\section{EDYS model}

The Ecological Dynamics Simulation (EDYS) model is a PC-based, mechanistic, spatially explicit, and temporally dynamic simulation model developed by Terry McLendon, Michael Childress, and Cade Coldren (Childress and McLendon 1999, Childress et al. 1999a, 1999b). EDYS simulates changes in soil, water, plant, animal, and landscape components resulting from natural and anthropogenic ecological stressors (McLendon et al. 1999, Childress et al. 2002). EDYS has been applied to over 40 ecological communities, including deserts, forests, grasslands, shrublands, wetlands, salt marshes, woodlands, and highly disturbed areas. Application locations include Arizona, California, Colorado, Maine, Montana, Nevada, New Mexico, Texas, Utah, Washington, Wyoming, Australia, and Indonesia.

EDYS consists of Climate, Soil, Hydrologic, Plant, Animal, Stressor, Spatial, Landscape, Management, and Simulation Control modules.

- In the Climatic Module, precipitation and wind inputs can be historical, stochastically generated, or a combination of both.

- The Soil Module is divided into layers (horizons, subhorizons, or artificial layers), the number, depth, and physical and chemical characteristics of which are site-specific for each application.

- The Hydrologic Module provides for infiltration and water movement through the soil profile, surface movement of water, surface erosion, sediment transport, subsurface movement of water, and changes in water quality.

- The Plant Module includes above- and below-ground components for each species included in each user-defined suite. Plant growth is dynamic in relation to plant components (roots, trunk, stems, leaves, seeds, and standing dead), season, resource requirements (water, 
nutrients, sunlight), and stressors (e.g., herbivory, competition, fire, trampling, chemical contaminants).

- The Animal Module consists of basic population parameters and diet attributes (preferences, utilization potential, competitive success) for each species (e.g., insects, rodents, native ungulates, livestock).

- The Stressor Module includes drought, nutrient availability, fire, herbivory, contaminants, shading, and competition for soil moisture and nutrients.

- The Spatial Module allows growth of individual plants (e.g., trees) and distribution patterns (e.g., colonies, fire patterns, soil heterogeneity) to be explicitly represented in the simulations.

- The Landscape Module allows for multi-scale simulations: plots (typically 1-100 $\mathrm{m}^{2}$ ), communities (typically 1-100 hectares), and landscapes $\left(1 \mathrm{~km}^{2}\right.$ and larger).

- The Management Module allows simulation of a variety of management activities, including agriculture, revegetation, weed and brush control, construction, reclamation, recreation, and military training.

- The Simulation Control Module coordinates the timing of simulation of ecological processes, allowing time-steps for different processes to vary from daily (e.g., precipitation events, plant water demand, fire, herbivory), to monthly (e.g., species composition), to annual and longer (e.g., climatic cycles).

\section{EDYS structure}

EDYS is designed to simultaneously simulate ecosystem dynamics at three different spatial scales: plots, communities, and landscapes (Figure 5).

Plot-level dynamics in EDYS simulate ecological dynamics at the small scale (typically, $1 \mathrm{~m}^{2}$ to $100 \mathrm{~m}^{2}$ ), including biomasses of different plant species over time (bar chart in Figure 5). Most of the mechanistic processes in EDYS related to plants (e.g., growth, water and nutrient uptake, and competition) and soils (e.g., water and nutrient transport through the profile, decomposition) are implemented at this level (Figure 6). 


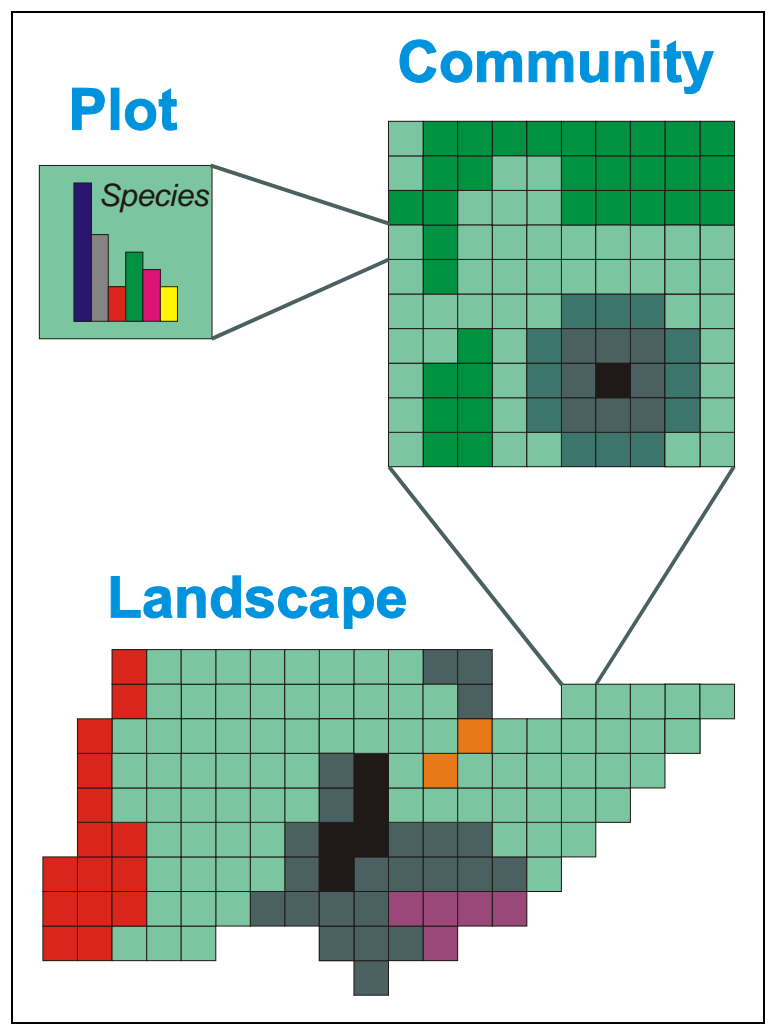

Figure 5. Multiple scales represented in EDYS simulations.

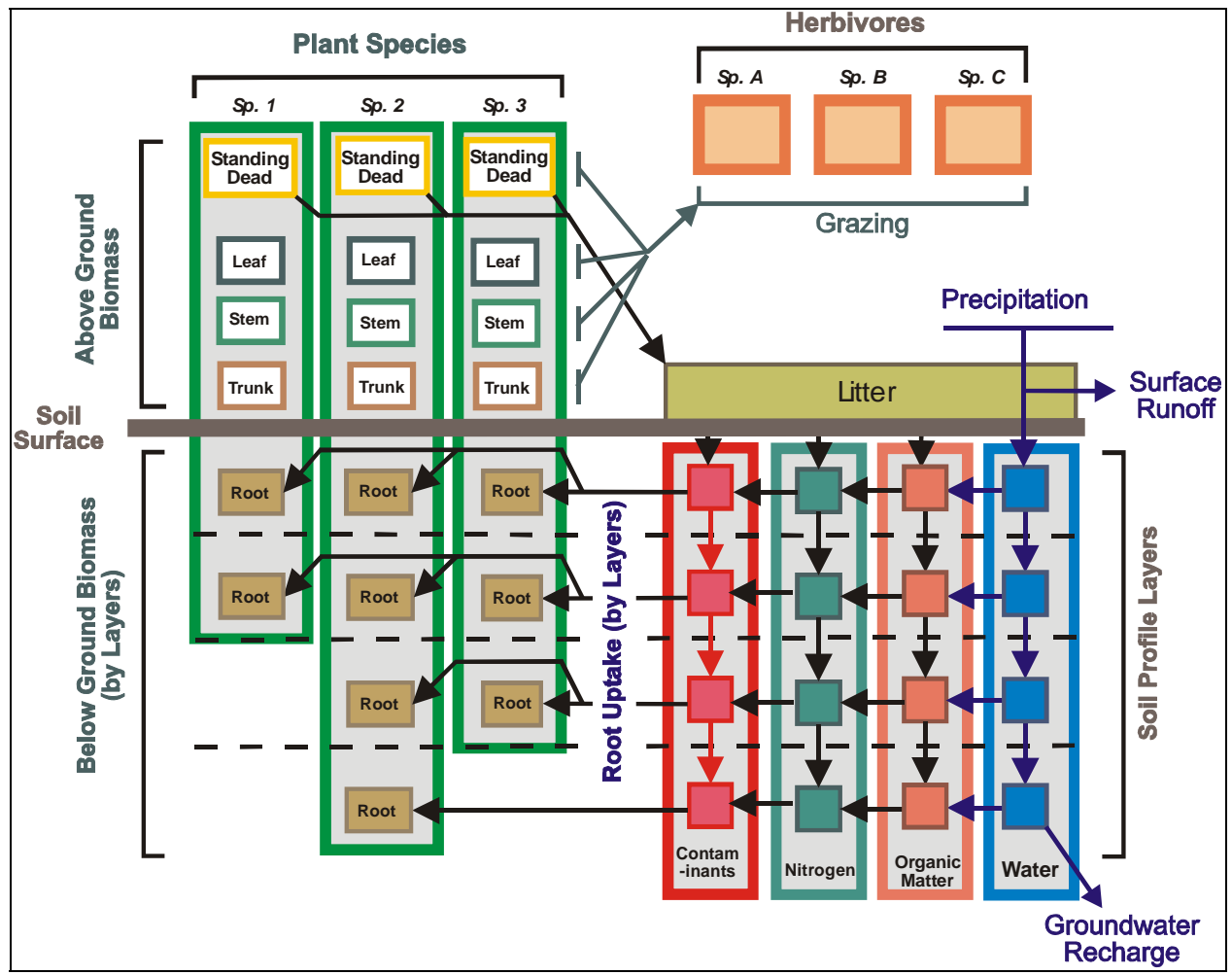

Figure 6. Plot-level structure of the EDYS general ecosystem model. 
Different plots are represented as cells in the community grid (Figure 5). The Community Module focuses on spatial patterns and dynamics from the plot to the community scales. These include spatial heterogeneity in soils, plants, and stressors among plots within the community, stressors such as fire propagation, grazing, and lateral flow of surface and subsurface water and materials, and important spatial patterns such as vegetation cover, habitats, and topography.

In an analogous manner, communities are the basic units in the Landscape Grid (Figure 5). This largest scale focuses on ecological processes operating at large spatial scales ( $1 \mathrm{~km}^{2}$ and larger). These include fire initiation regimes, climatic regimes, watershed-level water movement and transport of materials, and management practices such as revegetation, grazing operations, irrigation, weed control, and military training.

\section{EDYS soil module}

Soil profiles in EDYS are comprised of multiple layers, the number of which may vary between soil series and applications (Figure 6). The following characteristics are used to describe each layer:

- Depth

- Texture (\% sand, silt, and clay)

- Rock and gravel content

- Water-holding capacities (wilting point, field capacity, saturation)

- Organic matter content

- Nutrient content

- Compaction

- Chemical composition (e.g., pH and constituent concentrations).

Water-holding capacities are calculated as follows (all equations derived from Saxton et al. 1986). For all calculations, Sand is percent sand and Clay is percent clay.

Saturation:

$$
S A T=0.332-\left(7.251 e^{-4} *(\text { Sand })\right)+0.1276 * \log _{10}(\text { Clay })
$$


Field Capacity:

$$
\begin{aligned}
& F C=\left(\frac{0.3333}{A}\right)^{(1 / B)}
\end{aligned}
$$

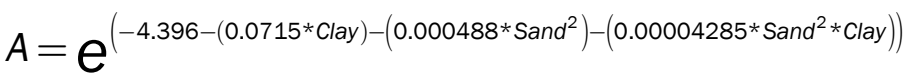

$$
\begin{aligned}
& B=-3.140-\left(0.00222 *\left(\text { Clay }^{2}\right)-\left(0.00003484 *\left(\text { Sand }^{2}\right) * \text { Clay }\right)\right)
\end{aligned}
$$

Wilting Point:

$$
\begin{gathered}
W P=\left(\frac{15.0}{A}\right)^{(1 / B)} \\
A=e^{\left(-4.396-(0.0715 * \text { Clay })-\left(0.000488 * S^{2} d^{2}\right)-\left(0.00004285 * S_{\text {Sand }}^{2 *} \text { Clay }\right)\right)} \\
B=-3.140-\left(0.00222 *\left(\text { Clay }^{2}\right)-\left(0.00003484 *\left(\text { Sand }^{2}\right) * \text { Clay }\right)\right)
\end{gathered}
$$

\section{EDYS hydrological module}

Hydrological dynamics are central in the EDYS model. Available water is often a limiting resource for plant growth and decomposition, and provides transport for nutrients and contaminants. Precipitation and groundwater elevation are external inputs to the EDYS simulations, so different precipitation patterns and groundwater contours are evaluated using a series of scenarios. Precipitation inputs are typically derived from historical data from nearby weather stations, but may also be stochastically generated, with scenarios representing average, wet, and dry periods.

In addition to precipitation, there are numerous other hydrological flows at the plot level in the EDYS model (Figure 7). Rather than assigning a fixed percentage of precipitation to interception, evaporation, and transpiration, EDYS calculates these losses on a daily basis as functions of current plant biomass and existing soil moisture. In particular, transpiration is computed as uptake of water from different soil horizons based on the presence of roots in each horizon and the daily water demand of each plant species. Infiltration into the soil profile is simulated using a simple 


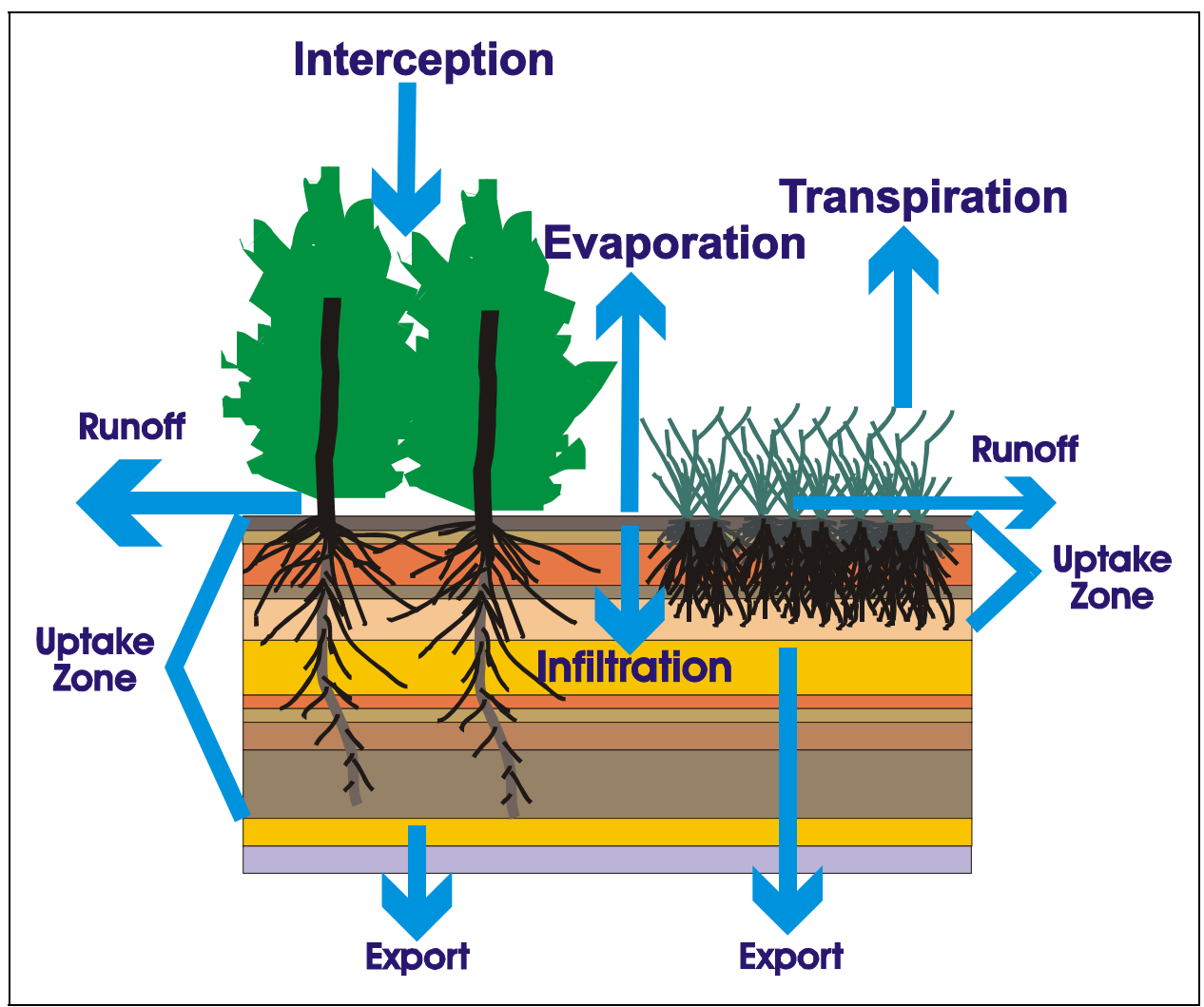

Figure 7. Plot-level hydrological dynamics in the EDYS model.

tipping bucket algorithm based on permeabilities and water-holding capacities of each soil horizon. EDYS also simulates surface runoff and shallow subsurface vertical and lateral flows among plot cells in the landscape grid (Figure 8) and calculates recharge and uptake of groundwater in each cell across the landscape.

\section{EDYS plant module}

The Plant Module models plant dynamics by simulating individual species responses to resource availability, competition, and various stressors. Each species is represented by its constituent components (coarse roots, fine roots, trunks, stems, leaves, seeds, and standing dead material). Species are also represented by age classes (i.e., mature plants, seedlings, and saplings) and by a seedbank. A series of plant parameters (Table 1) governs all plant mechanisms, including growth, competition for resources (light, water, and nutrients), and response to stressors (e.g., chemical contaminants, fire, herbivory, and military training). 


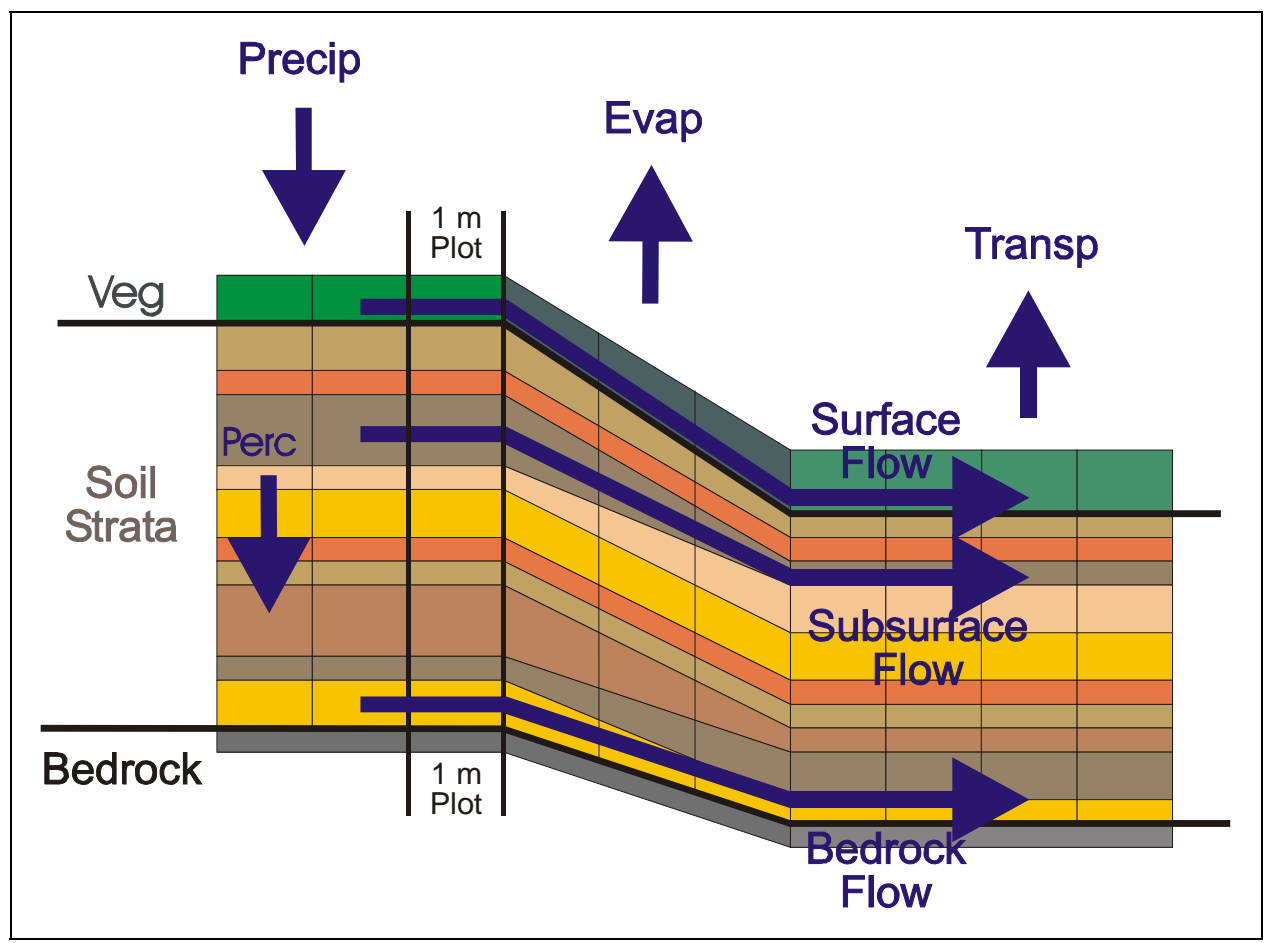

Figure 8. Landscape-level hydrology in the EDYS model.

Table 1. Plant parameters used by EDYS to simulate plant dynamics.

\begin{tabular}{|l|l|}
\hline Parameter & Function within EDYS \\
\hline Mature allocation & Distribution of biomass by plant component for mature plants \\
\hline Current allocation & Distribution of biomass by plant component for new growth \\
\hline Green-out allocation & $\begin{array}{l}\text { Distribution of biomass by plant component for new growth at } \\
\text { green-out }\end{array}$ \\
\hline Seed month allocation & $\begin{array}{l}\text { Distribution of biomass by plant component for new growth when } \\
\text { seeds are being produced }\end{array}$ \\
\hline Initial nitrogen concentration & Initial nitrogen concentration by plant component \\
\hline Maintenance nitrogen concentration & $\begin{array}{l}\text { Nitrogen concentration by plant component required for } \\
\text { maintenance }\end{array}$ \\
\hline Nitrogen resorption & Proportion of nitrogen that may be resorbed prior to senescence \\
\hline Root architecture & Distribution of root biomass by soil layer \\
\hline Maximum rooting depth & Maximum possible rooting depth \\
\hline Root saturation death loss & Proportion of root biomass loss due to saturated soil conditions \\
\hline Root uptake capacity & $\begin{array}{l}\text { Proportion of monthly water demand that may be obtained in a } \\
\text { single day }\end{array}$ \\
\hline Root competitive efficiency & Relative competitive efficiency for obtaining soil moisture \\
\hline Green-out month & Start of the growing season \\
\hline Seed germination month & Months when seeds may germinate \\
\hline Seed set month & Months when plants may produce seeds \\
\hline Die-back month & Month when dormancy begins \\
\hline
\end{tabular}




\begin{tabular}{|l|l|}
\hline Parameter & Function within EDYS \\
\hline Dry weight/wet weight & Dry weight to wet weight conversion factor \\
\hline Moisture interception & $\begin{array}{l}\text { Conversion factor for aboveground biomass to precipitation loss } \\
\text { from interception }\end{array}$ \\
\hline Trunk biomass/basal cover & Conversion factor for trunk biomass to basal cover \\
\hline Maintenance water use & Water demand for maintenance of old growth \\
\hline New biomass maintenance water use & Water demand for maintenance of new biomass \\
\hline Water use efficiency & Amount of water needed to produce 1 gm of new growth \\
\hline Green-out water use & Relative water use efficiency for green-out conditions \\
\hline Maximum old-growth drought loss & Maximum biomass loss of old growth during drought conditions \\
\hline Maximum growth rate & Maximum growth rate that may be achieved under ideal conditions \\
\hline Maximum biomass limit & $\begin{array}{l}\text { Maximum aboveground biomass that may be achieved under ideal } \\
\text { conditions }\end{array}$ \\
\hline Monthly maximum growth rate & Seasonal changes in maximum growth potential \\
\hline Plant part productivity & $\begin{array}{l}\text { Relative contribution by plant component to new growth, based on } \\
\text { distribution of photosynthetic material within a plant }\end{array}$ \\
\hline Green-out plant part productivity & $\begin{array}{l}\text { Relative contribution by plant component to new growth during } \\
\text { green-out conditions }\end{array}$ \\
\hline Light competition factor & Relative sensitivity to shading by other species in the community \\
\hline Maximum growing season root:shoot & Maximum allowable root:shoot ratio \\
\hline Green-out root:shoot trigger & Minimum root:shoot ratio that will trigger green-out conditions \\
\hline Maximum 1-month seed germination & Proportion of seed bank that may germinate during any one month \\
\hline Maximum 1st month seedling growth & Maximum seedling growth rate during first month after germination \\
\hline End of growing season die-back & Proportion of biomass loss due to senescence \\
\hline Die-back fate & Fate of biomass when die-back occurs \\
\hline Losses to fire events & Proportion of biomass lost by plant component to fire events \\
\hline Fuel combustibility factor & Contribution by plant component to fuel load \\
\hline Loss to trampling or single vehicle \\
pass & $\begin{array}{l}\text { Proportion of biomass lost by plant component to trampling or to a } \\
\text { single vehicle pass }\end{array}$ \\
\hline & \\
\hline
\end{tabular}

\section{EDYS spatial module}

EDYS represents spatial heterogeneity by assigning plot types to multiple grid cells across the simulation landscape. Each plot type represents a unique combination of soils and plants. Additionally, each cell is assigned topographic data (e.g. elevation, slope, aspect). Patterns of land use are imposed upon the vegetation and topography. This multi-tiered approach allows EDYS to represent disturbance patterns and management activities in a realistic, spatially explicit manner. 


\section{EDYS nutrient dynamics}

The primary nutrient modeled in EDYS is nitrogen (Figure 9), largely because it is an important factor in driving plant successional dynamics. Other nutrients, such as phosphorous, can be simulated by EDYS if their dynamics are of importance for a particular application.

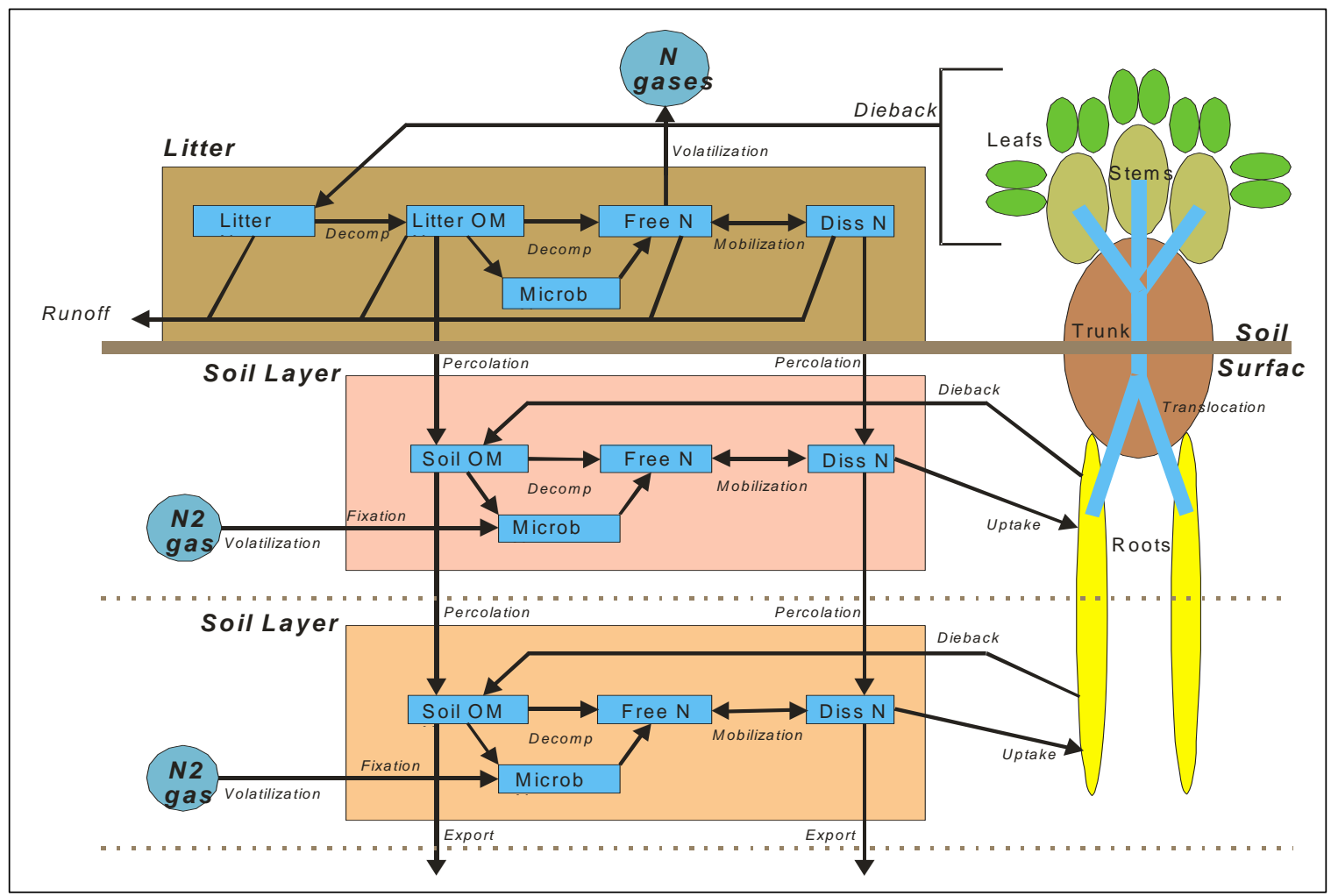

Figure 9. Plot-level nitrogen dynamics in EDYS.

\section{EDYS flowchart}

EDYS uses several time-steps, ranging from days to years, to simulate different ecological and hydrological processes during each simulation run (Figure 10). Hydrological processes are for the most part computed daily, along with plant uptake of water and nutrients. Other plant dynamics, such as growth and seed set, are computed monthly and then disaggregated during the month on a daily basis. Management practices, such as physical disturbances, recreational use, and natural fire, are treated in the same manner. 


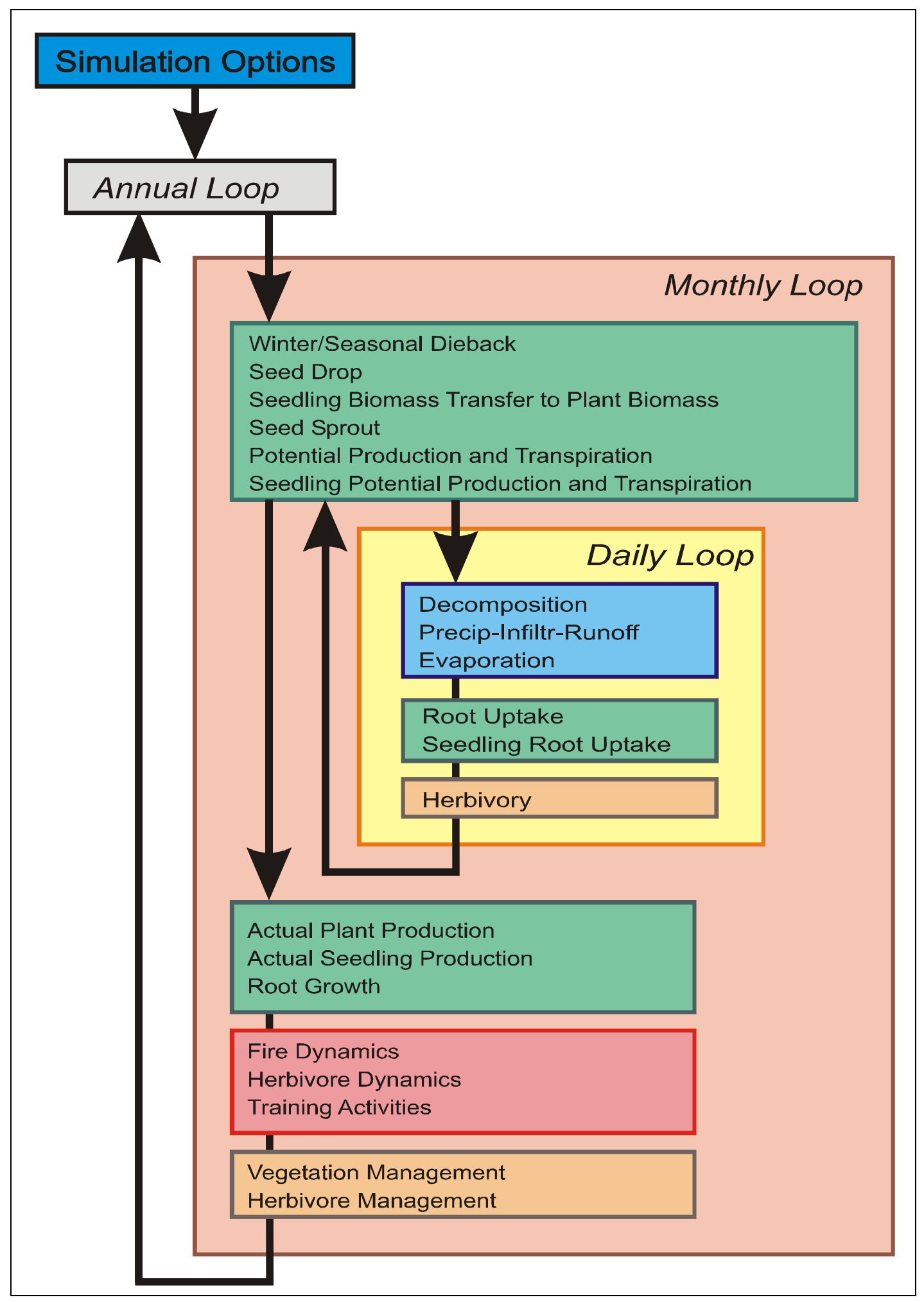

Figure 10. Simulation flowchart for the EDYS model. 


\section{Manual Linkage Setup}

The current approach to linking GSSHA with EDYS involves the transfer of soil moisture values via output files between the two modeling systems.

The first transfer occurs at the start of an event to be simulated by GSSHA, when EDYS outputs the current soil moisture conditions prior to launching GSSHA. After GSSHA terminates, the second transfer occurs when EDYS reads a GSSHA output file containing soil moisture conditions at the conclusion of the precipitation event. EDYS then uses those data to set soil moisture levels prior to continuing its daily operations.

The steps below detail the actual sequence of events during a GSSHAEDYS linked run:

1. At the start of the simulation, EDYS reads the "event_all.gag" file to compile a list of precipitation events to be simulated by GSSHA and builds a matrix used by EDYS to control the simulation sequence. This matrix includes event year, month, day, and duration (in days).

2. If not previously configured, EDYS will create the necessary directory structures for saving GSSHA outputs.

3. At the start of a precipitation event:

a. EDYS reads the effective porosity grid "ep10.dat."

b. EDYS reads the residual saturation grid "rs.dat."

c. EDYS writes out current soil moisture conditions to the initial soil moisture "ism.dat" file. Soil depth for reporting is set at $400 \mathrm{~mm}$. For each grid cell, the following processing steps are conducted:

- Soil moisture is totaled for all layers contained in the top $400 \mathrm{~mm}$.

- Percent soil moisture by depth is calculated and multiplied by the effective porosity.

- Soil moisture is then compared to the residual saturation value. If less than residual saturation for that cell, then soil moisture is set to "residual saturation +0.01 ."

d. EDYS launches GSSHA for that event.

4. After GSSHA completes execution:

a. EDYS finds the last surface moisture output file generated by GSSHA.

b. EDYS reads the surface moisture value for each cell.

c. Moisture is converted to percentage of soil moisture by dividing by the effective porosity. 
d. EDYS sets moisture content for each soil layer contained within the 400-mm depth. If the content exceeds saturation level, then moisture is set to saturation.

5. EDYS then continues execution on the next day using the updated soil moisturevalues.

Existing data transfer

Currently, the mechanism has been developed whereby soil moisture maps can be transferred between the two modeling systems. While no other data layers are being transferred, it is relatively simple to add more water budget and ecological data layers to the data transfer modules.

Future data transfer

Future data transfers will encompass a wide variety of data types. Infiltration and Evapotranspiration data layers will be transferred in order to perform long-term simulations. Parameters associated with land use and soil type will allow one to alter the hydraulic flow computations based upon land use changes and training scenarios. As the nutrient sub-models become more developed, plant uptake and biomass loading will become available and will allow better tracking of nutrient fate and transport throughout the watershed. 


\section{Case Study - Cibolo Creek Watershed}

\section{Watershed description}

The Cibolo Creek Watershed lies along the southern edge of the Edwards Plateau Ecoregion in central Texas, also known locally as the Texas Hill Country. The topography in this ecoregion is hilly and is commonly dissected by streams. Average rainfall across the Edwards Plateau ranges from 16 to 33 in. annually. Soils are shallow and usually underlain with limestone or caliche.

The Cibolo Creek watershed encompasses portions of Bandera, Bexar, Comal, and Kendall counties and includes the communities of Boerne and Bulverde. The model domain extends roughly from IH-10 east of San Antonio west to approximately 11 miles (18 km) west of Boerne, totaling 70,770 hectares (174,877 acres). Elevations within the model domain, Figure 11, range from $228 \mathrm{~m}$ ( $748 \mathrm{ft}$.) to $612 \mathrm{~m}$ (2008 ft.). Dominant native vegetation is a mixture of Ashe juniper (J uniperus ashei) - live oak (Quercus virginiana) woodlands and grasslands.

\section{Hydrologic data input}

The hydrologic data used in the distributed rainfall runoff modeling effort were furnished by engineers and scientists at the U.S. Geological Survey (USGS) and Montgomery Watson Harza Global, Inc (MWH). The following figures and tables describe the input data used to compute surface runoff and soil moisture contents. The soil moisture data layers were exchanged between GSSHA and EDYS in an effort to develop the proper data exchange protocol such that future water and nutrient data layers can be exchanged between the two modeling systems during long-term simulations. 


\section{Cibolo Creek Watershed}
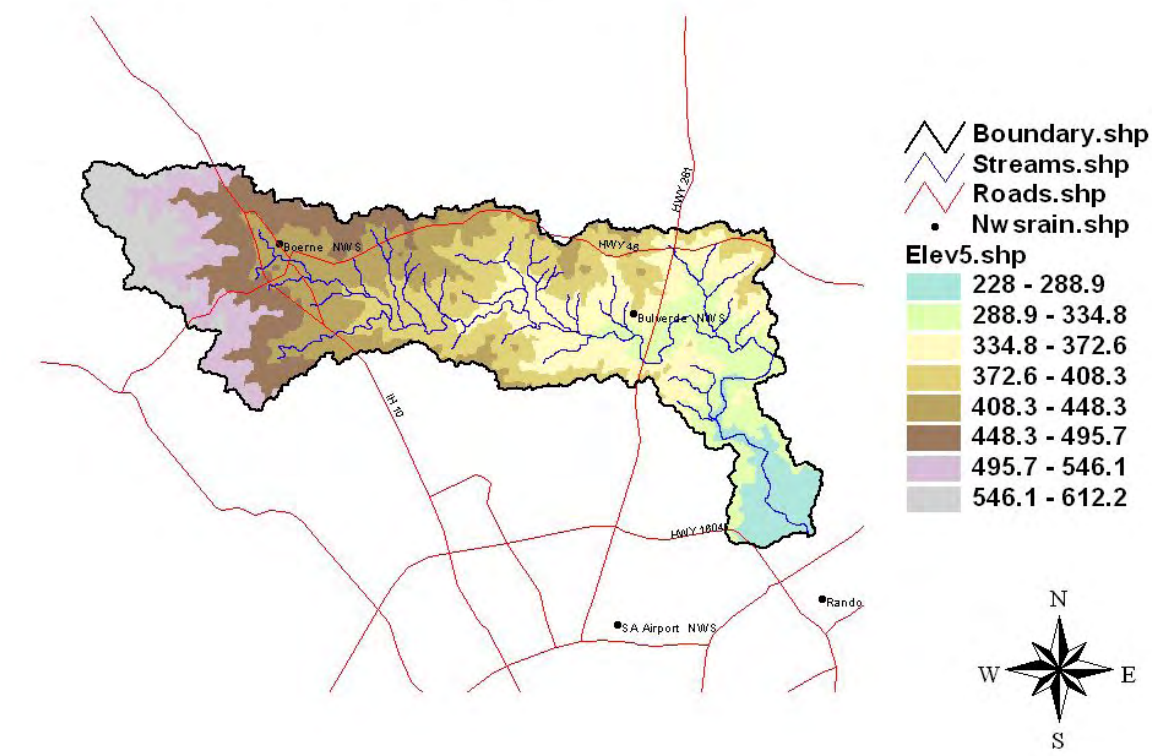

Figure 11. Digitial elevation map (120 m) for Cibolo Creek Watershed.

\section{Cibolo Creek Watershed}
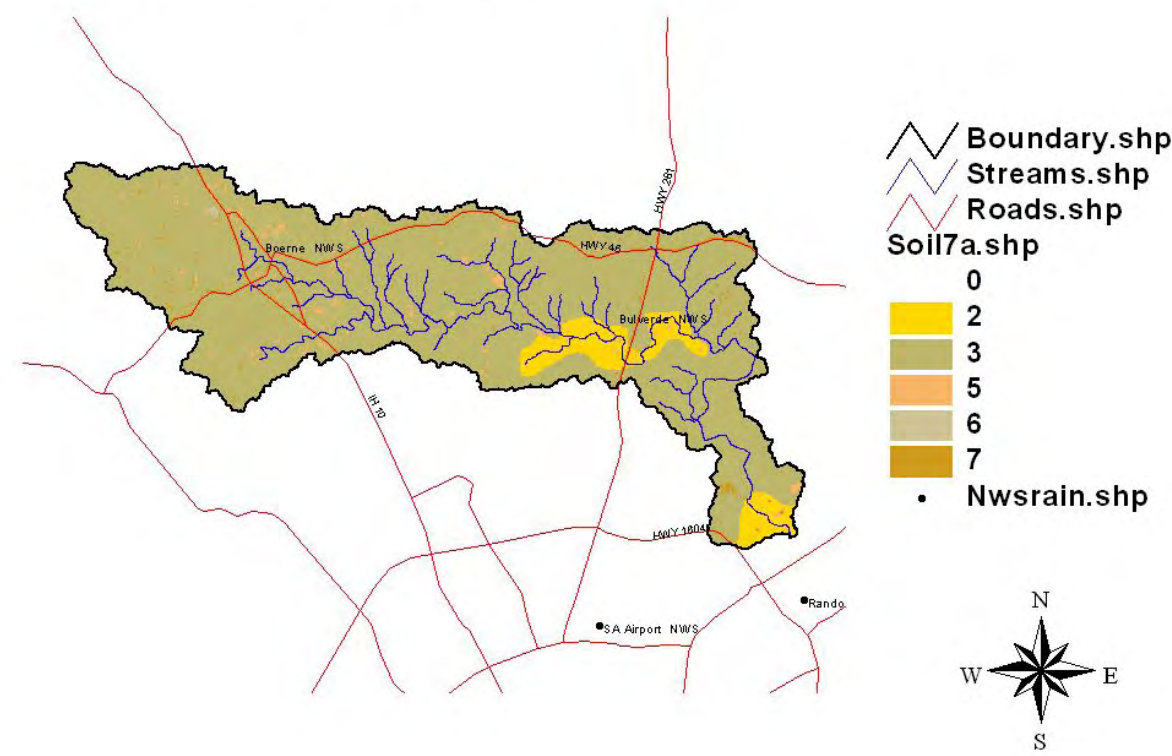

Figure 12. Soil texture map for Cibolo Creek Watershed. 
Table 2. Estimated soil parameters.

\begin{tabular}{|l|l|l|l|l|l|}
\hline $\begin{array}{l}\text { Map } \\
\text { ID }\end{array}$ & Description & $\begin{array}{l}\text { Estimated } \\
\text { Soil Texture }\end{array}$ & $\begin{array}{l}\text { Hydraulic } \\
\text { Conductivity } \\
\mathrm{cm} / \mathrm{h}\end{array}$ & $\begin{array}{l}\text { Capillary } \\
\text { Head } \\
\mathrm{cm}\end{array}$ & $\begin{array}{l}\text { Effective } \\
\text { Porosity }\end{array}$ \\
\hline 2 & $\begin{array}{l}\text { brackett-comfort-real } \\
\text { (tarrant-brackett) }\end{array}$ & $\begin{array}{l}\text { Clay } \\
\text { Loam }\end{array}$ & 0.20 & 20.88 & 0.390 \\
\hline 3 & hockley-web-crockett & $\begin{array}{l}\text { Sandy } \\
\text { Loam }\end{array}$ & 0.52 & 18.33 & 0.486 \\
\hline 5 & LULC 11 (Residential) & & 0.03 & 31.63 & 0.385 \\
\hline 6 & LULC 16 (Commercial) & & 0.01 & 31.63 & 0.385 \\
\hline
\end{tabular}

\section{Cibolo Creek Watershed}
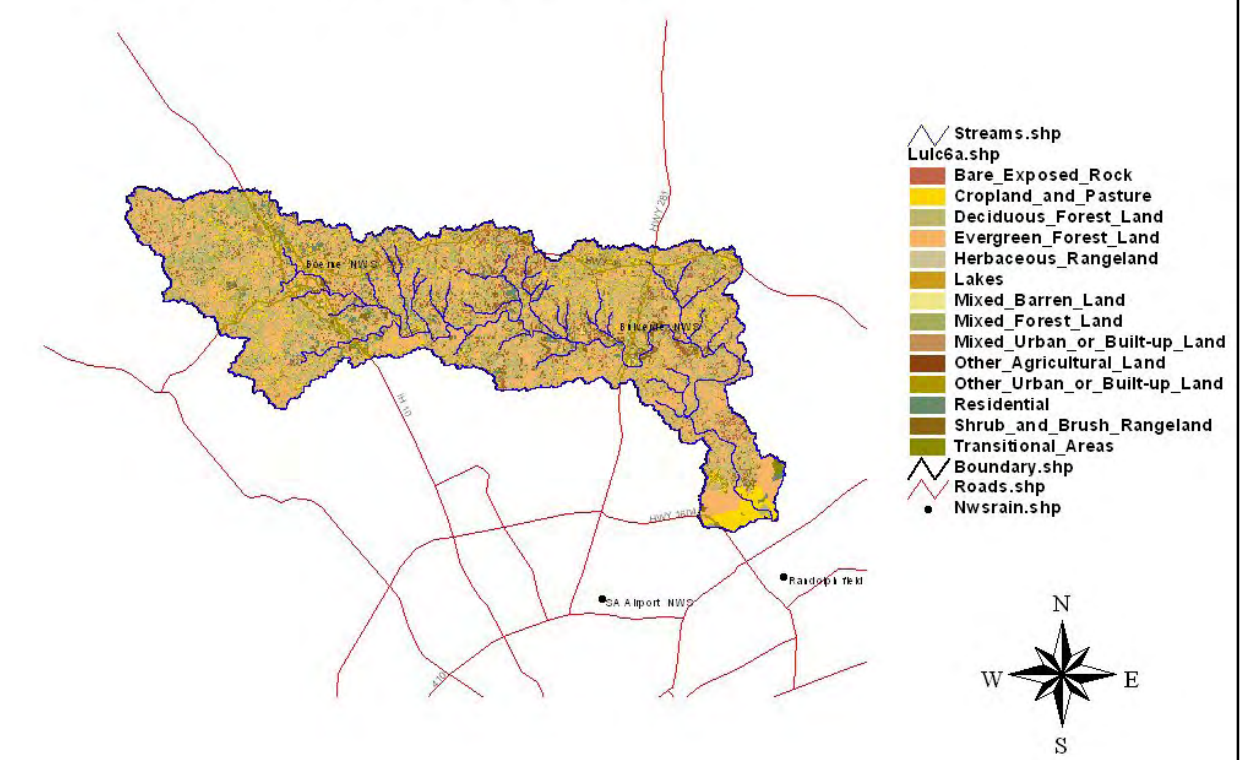

Figure 13. Land use map for Cibolo Creek Watershed. 
Table 3. Estimated land use parameters.

\begin{tabular}{|l|l|l|l|l|l|l|}
\hline $\begin{array}{l}\text { Map } \\
\text { ID }\end{array}$ & Description & $\begin{array}{l}\text { Roughness } \\
\text { Coefficient }\end{array}$ & $\begin{array}{l}\text { Storage } \\
\text { Capacity }\end{array}$ & $\begin{array}{l}\text { Interception } \\
\text { Coefficient }\end{array}$ & Albedo & $\begin{array}{l}\text { Wilting } \\
\text { Point }\end{array}$ \\
\hline 11 & Residential & 0.050 & 0.000 & 0.00 & 0.40 & 0.28 \\
\hline 16 & $\begin{array}{l}\text { Mixed Urban } \\
\text { or Built-up Land }\end{array}$ & 0.050 & 0.000 & 0.00 & 0.35 & 0.25 \\
\hline 17 & $\begin{array}{l}\text { Other Urban } \\
\text { or Built-up Land }\end{array}$ & 0.030 & 0.000 & 0.00 & 0.35 & 0.25 \\
\hline 21 & $\begin{array}{l}\text { Cropland and } \\
\text { Pasture }\end{array}$ & 0.055 & 0.010 & 0.16 & 0.15 & 0.15 \\
\hline 24 & $\begin{array}{l}\text { Other Agricultural } \\
\text { Land }\end{array}$ & 0.057 & 0.010 & 0.10 & 0.20 & 0.18 \\
\hline 31 & $\begin{array}{l}\text { Herbaceous } \\
\text { Rangeland }\end{array}$ & 0.060 & 0.010 & 0.16 & 0.25 & 0.21 \\
\hline 32 & $\begin{array}{l}\text { Shrub and Brush } \\
\text { Rangeland }\end{array}$ & 0.100 & 0.020 & 0.40 & 0.30 & 0.23 \\
\hline 41 & $\begin{array}{l}\text { Deciduous Forest } \\
\text { Land }\end{array}$ & 0.066 & 0.040 & 0.18 & 0.10 & 0.10 \\
\hline 42 & $\begin{array}{l}\text { Evergreen Forest } \\
\text { Land }\end{array}$ & 0.067 & 0.050 & 0.20 & 0.10 & 0.10 \\
\hline 43 & $\begin{array}{l}\text { Mixed } \\
\text { Forest Land }\end{array}$ & 0.068 & 0.045 & 0.19 & 0.10 & 0.10 \\
\hline
\end{tabular}

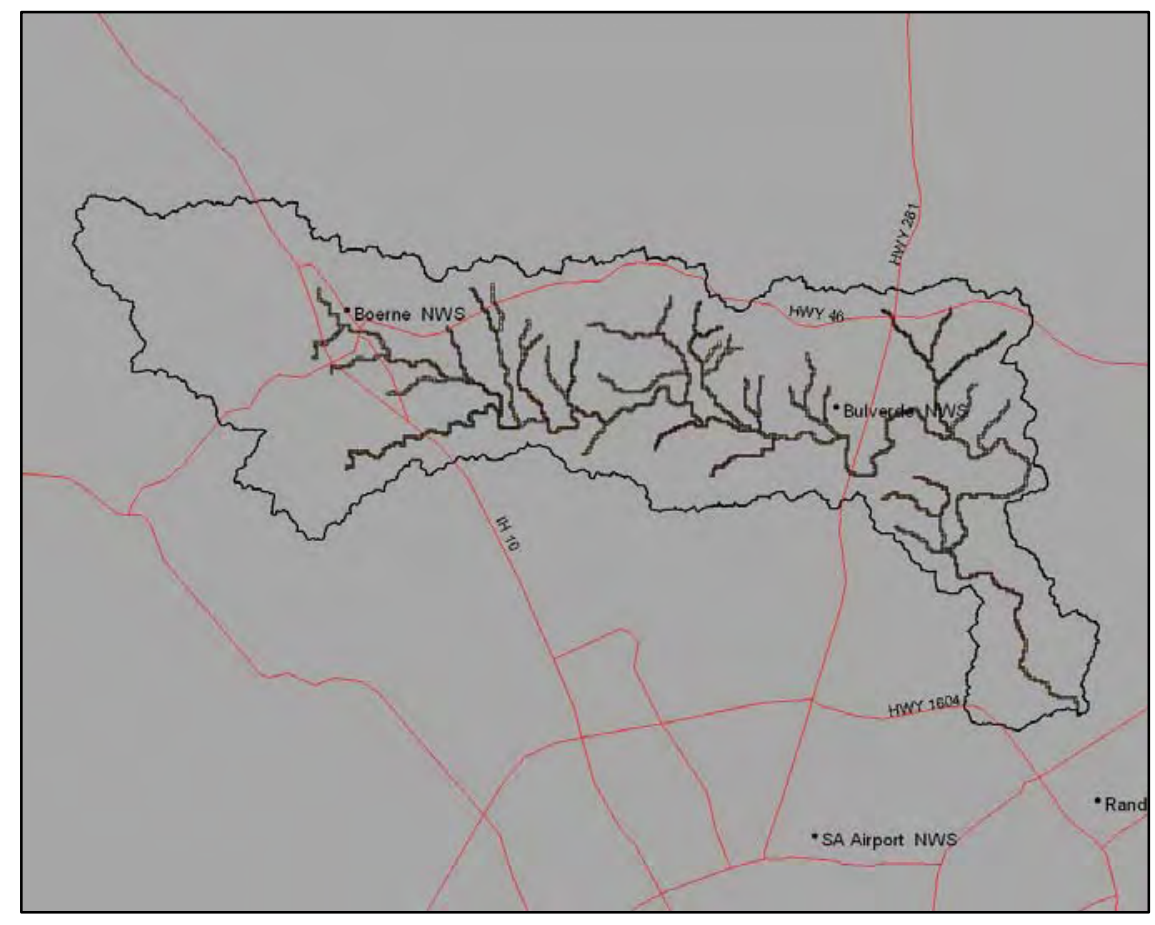

Figure 14. Rain gage locations (two gages) and stream network. 


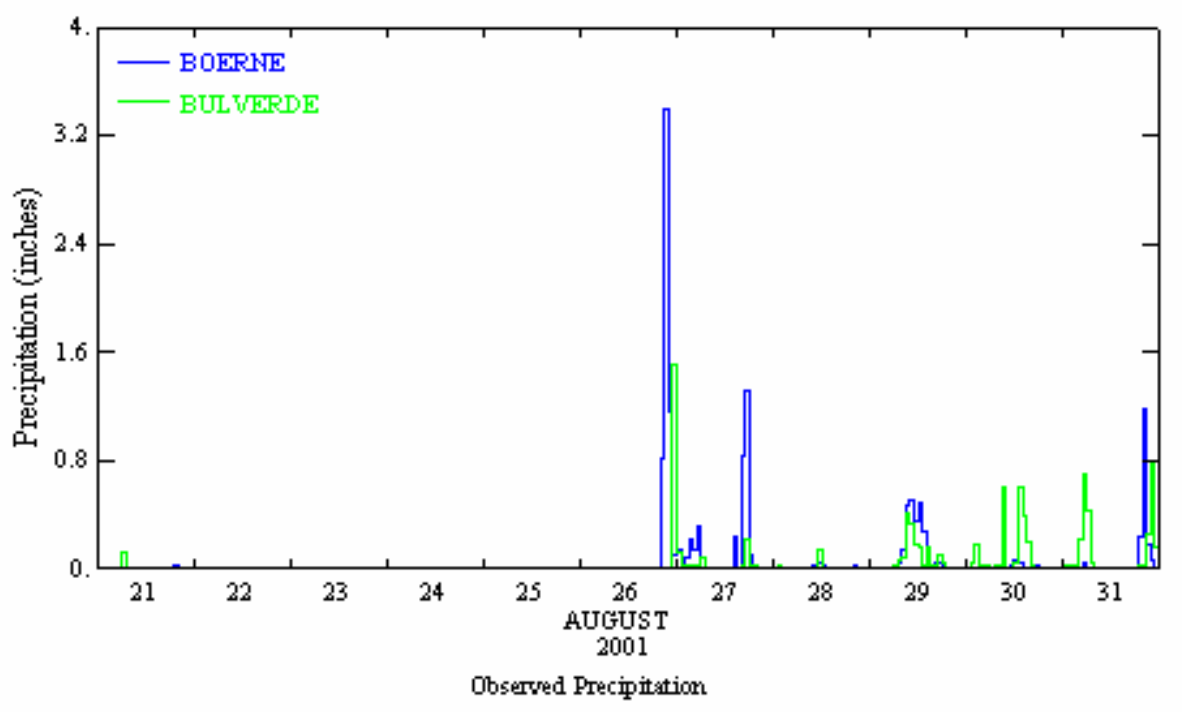

Figure 15. Precipitation depth for Boerne and Bulverde Gages.

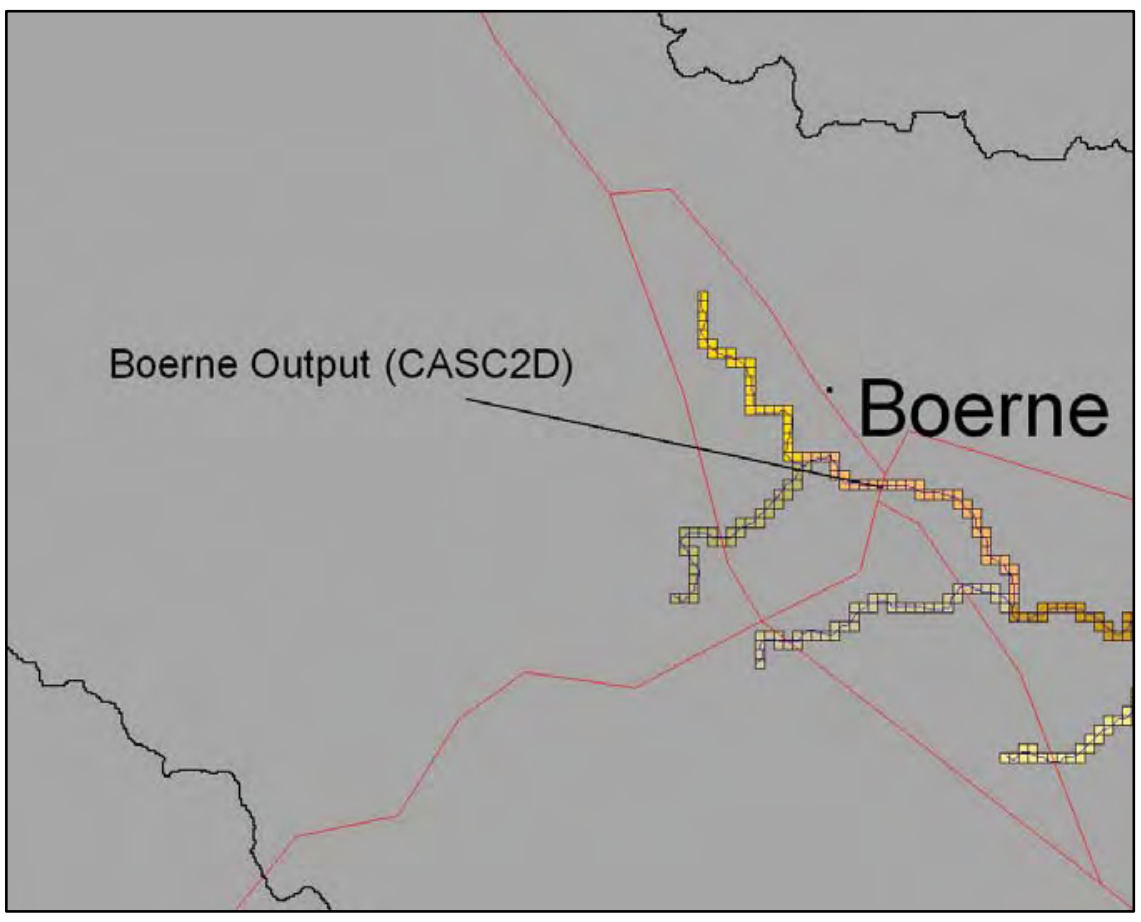

Figure 16. Flow comparison location for Boerne Gage site. 


\section{EDYS data input}

The input data used for the ecological modeling effort were obtained from a variety of sources, including scientists from U. S. Geological Survey (USGS), Natural Resources Conservation Service (NRCS), and U.S. Army Corps of Engineers. Additional details on the EDYS application developed for the Cibolo Creek Watershed are described in Price et al. (2004). Specific details on input data not contained in Price et al. (2004) are described below.

\section{Soils}

Multiple soil series may occur within each vegetation community. To determine the soil series for each community, soil series maps were overlaid with vegetation maps to identify the soil series most commonly found within each community. This approach yielded nine series (Table 4). Soil characteristics for each were derived from data obtained from NRCS official soil series descriptions (http://www.statlab.iastate .edu/soils/osd) and from U.S. Soil Conservation Service classifications (USSCS 1975). Specifics for each soil series are presented in Appendix A.

Table 4. Soil series modeled in the EDYS application for Cibolo Creek Watershed.

\begin{tabular}{|l|}
\hline Soil Series \\
\hline Anhalt Clay \\
\hline Brackett-Real Association \\
\hline $\begin{array}{l}\text { Brackett-Rock Outcrop-Comfort } \\
\text { Complex }\end{array}$ \\
\hline Comfort-Rock Outcrop Complex \\
\hline Denton Silty Clay \\
\hline Doss-Brackett Association \\
\hline Eckrant-Rock Outcrop Complex \\
\hline Krum Silty Clay \\
\hline Lewisville Silty Clay \\
\hline
\end{tabular}

\section{Plants}

Sixteen native plant communities were included in the EDYS model for Cibolo Creek (Table 5). Additionally, nine land use types were identified within the model domain, for a total of 25 types being simulated.

The number of plant species included in an EDYS application is flexible and is specified in the initial parameterization. Not all species occurring in an area are included in the EDYS application for two reasons. First, very few ecological data are available for minor species. Therefore, estimates based on the major species would have to be used. This estimation increases the uncertainty associated with the EDYS simulations. Second, most of the excluded species comprise relatively small amounts of the total composition. Thus, excluding them does not significantly impact most EDYS variables. 
Table 5. Vegetation communities and land use types.

\begin{tabular}{|l|}
\hline Community Name \\
\hline Ashe Juniper Woodland \\
\hline Ashe Juniper-Live Oak Woodland (very dense cover) \\
\hline Ashe Juniper-Live Oak Woodland (dense cover) \\
\hline Ashe Juniper-Live Oak Woodland (moderate cover) \\
\hline Ashe Juniper-Post Oak Woodland \\
\hline Oak-Ashe Juniper Woodland (moderate cover) \\
\hline Oak-Ashe Juniper Woodland (light cover) \\
\hline Oak-Persimmon Woodland (dense cover) \\
\hline Oak-Persimmon Woodland (moderate cover) \\
\hline Mixed Woodland \\
\hline Ashe Juniper-Persimmon Savanna \\
\hline Oak Savanna \\
\hline Mesquite Savanna \\
\hline Shrubland \\
\hline Bluestem Prairie \\
\hline Shortgrass Plains \\
\hline Improved Pasture \\
\hline Cultivation \\
\hline Urban Lawn \\
\hline Urban Buildings \\
\hline Roads \\
\hline Rock/Bare \\
\hline Water's Edge \\
\hline Water \\
\hline Channel \\
\hline
\end{tabular}

In order to account for overall community dynamics, the ecological contribution of each species not specifically included in the model must be accounted for. This is accomplished in EDYS by using composite species. In EDYS, a composite species consists of a major species plus those minor species most ecologically similar to the respective major species. Table 6 lists the composite species used in the EDYS application for Cibolo Creek. 
Table 6. Plant species used in the Cibolo Creek EDYS Model.

\begin{tabular}{|l|l|l|}
\hline Common Name & Scientific Name & Abbreviation \\
\hline Netleaf Hackberry & Celtis reticulata & NIHckbry \\
\hline Texas Persimmon & Diospyros texana & TxPrsmmn \\
\hline Ashe Juniper & Juniperus ashei & AsheJunp \\
\hline Shumard Red Oak & Quercus shumardii & ShRdOak \\
\hline Live Oak & Quercus virginiana & LvOak \\
\hline Cedar Elm & Ulmus crassifolia & CdrElm \\
\hline Honey Mesquite & Prosopis glandulosa & Mesquite \\
\hline Sotol & Dasylirion texanum & Sotol \\
\hline Evergreen Sumac & Rhus virens & EvgSumac \\
\hline Greenbriar & Smilax sp. & GrnBriar \\
\hline Mountain Grape & Vitis monticola & MtnGrape \\
\hline Annual Grass & & AnnlGrs \\
\hline Old-field Threeawn & Aristida oligantha & OfThrAn \\
\hline King Ranch Bluestem & Bothriochloa ischaemum & KRBluStm \\
\hline Silver Bluestem & Bothriochloa saccharoides & SiBluStm \\
\hline Sideoats Grama & Bouteloua curtipendula & SdOtsGrm \\
\hline Hairy Grama & Bouteloua hirsuta & HryGrm \\
\hline Bermudagrass & Cynodon dactylon & BrmdaGrs \\
\hline Texas Cupgrass & Eriochloa sericea & TxCupGrs \\
\hline Seep Muhly & Muhlenbergia reverchonii & SpMuhly \\
\hline Little Bluestem & Schizachyrium scoparium & LIBluStm \\
\hline Indiangrass & Sorghastrum nutans & IndnGrs \\
\hline Tall Dropseed & Sporobolus asper & TIDrpSd \\
\hline Texas Wintergrass & Stipa leucotricha & TxWntGrs \\
\hline Curly Mesquite & Hilaria belangeri & CrlyMsqt \\
\hline Broomweed & Amphiachyris dracunculoides & BrmWd \\
\hline Woodland Sedge & Carex blanda & WdSedge \\
\hline Rabbit Tobacco & Evax verna & RbtTbaco \\
\hline Prairie Bluets & Hedyotis nigricans & PrrBluet \\
\hline Prairie Coneflower & Ratibida columnaris & PrCnflwr \\
\hline Texas Sage & Salvia texana & TxSage \\
\hline Doveweed & DoveWeed \\
\hline
\end{tabular}

A substantial number of plant parameters are utilized in EDYS for simulating the dynamics of each species. These relate to growth, resource allocation, nutrient and water requirements, seasonality of different processes (e.g., growth, seed development, and winter die-back), root architecture, and competitive interactions. Values for each parameter were compiled from a wide range of sources in the ecological literature for each species. Typically, multiple values are available in the literature for these 
parameters, so specific values were selected based on communities similar to those found in the Cibolo Creek Watershed and previous experience modeling communities in the Edwards Plateau (McLendon et al. 2001, 2002). Specific values used in this EDYS application are presented in Appendix B. Table 7 lists the initial biomasses of plant species by community and land use type.

Table 7. Initial plant biomasses by plant community and land use type.

\begin{tabular}{|c|c|c|c|c|c|c|c|c|c|}
\hline \multicolumn{10}{|c|}{ Plant Communities } \\
\hline \multicolumn{10}{|c|}{1 - Ashe Juniper Woodland } \\
\hline TxPrsmmn & 79.8 & AsheJunp & 9746.1 & Sotol & 4.0 & OfThrAn & 0.3 & KRBluStm & 7.6 \\
\hline HryGrm & 0.2 & SpMuhly & 0.1 & TxWntGrs & 1.3 & CrlyMsqt & 0.5 & BrmWd & 0.1 \\
\hline WdSedge & 0.9 & RbtTbaco & 0.1 & PrrBluet & 0.1 & PrCnflwr & 0.1 & & \\
\hline \multicolumn{10}{|c|}{2 - Ashe Juniper-Live Oak Woodland (very dense cover) } \\
\hline TxPrsmmn & 119.8 & AsheJunp & 12000.0 & LvOak & 5081.3 & CdrElm & 264.1 & Sotol & 2.4 \\
\hline OfThrAn & 0.2 & SdOtsGrm & 0.3 & HryGrm & 0.2 & LIBluStm & 0.1 & TIDrpSd & 0.6 \\
\hline TxWntGrs & 1.3 & BrmWd & 0.1 & WdSedge & 1.5 & RbtTbaco & 0.1 & PrrBluet & 0.4 \\
\hline \multicolumn{10}{|c|}{3 - Ashe Juniper-Live Oak Woodland (dense cover) } \\
\hline NIHckbry & 119.3 & TxPrsmmn & 173.0 & AsheJunp & 8820.0 & ShRdOak & 199.0 & LvOak & 3022.6 \\
\hline CdrElm & 72.0 & OfThrAn & 0.3 & SdOtsGrm & 1.1 & HryGrm & 1.6 & TxCupGrs & 2.3 \\
\hline LIBluStm & 0.1 & TIDrpSd & 0.3 & TxWntGrs & 1.8 & CrlyMsqt & 0.3 & BrmWd & 0.1 \\
\hline WdSedge & 4.2 & RbtTbaco & 0.1 & PrrBluet & 0.2 & PrCnflwr & 0.1 & TxSage & 0.1 \\
\hline DoveWeed & 0.5 & & & & & & & & \\
\hline \multicolumn{10}{|c|}{4 - Ashe Juniper-Live Oak Woodland (moderate cover) } \\
\hline TxPrsmmn & 279.5 & AsheJunp & 5350.8 & LvOak & 2963.1 & CdrElm & 12.0 & Sotol & 31.3 \\
\hline EvgSumac & 14.0 & GrnBriar & 17.8 & MtnGrape & 10.4 & OfThrAn & 1.7 & KRBluStm & 4.5 \\
\hline SdOtsGrm & 1.1 & HryGrm & 1.4 & TxCupGrs & 1.8 & SpMuhly & 0.2 & LIBluStm & 0.1 \\
\hline TIDrpSd & 2.2 & TxWntGrs & 5.6 & CrlyMsqt & 2.4 & BrmWd & 0.2 & WdSedge & 1.2 \\
\hline RbtTbaco & 0.2 & PrrBluet & 0.2 & PrCnflwr & 3.8 & TxSage & 1.2 & DoveWeed & 0.8 \\
\hline \multicolumn{10}{|c|}{5 - Ashe Juniper-Post Oak Woodland } \\
\hline AsheJunp & 4263.0 & ShRdOak & 995.1 & CdrElm & 108.0 & KRBluStm & 105.3 & TIDrpSd & 1.4 \\
\hline TxWntGrs & 3.2 & WdSedge & 1.5 & PrrBluet & 0.1 & PrCnflwr & 82.1 & & \\
\hline \multicolumn{10}{|c|}{6 - Oak-Ashe Juniper Woodland (moderate cover) } \\
\hline NIHckbry & 59.7 & TxPrsmmn & 20.0 & AsheJunp & 4557.0 & LvOak & 5247.9 & CdrElm & 660.1 \\
\hline Mesquite & 9.5 & Sotol & 4.7 & EvgSumac & 1.9 & GrnBriar & 6.5 & OfThrAn & 2.2 \\
\hline KRBluStm & 2.6 & SiBluStm & 0.4 & SdOtsGrm & 2.7 & HryGrm & 0.3 & TxCupGrs & 0.3 \\
\hline SpMuhly & 0.7 & LIBluStm & 0.1 & TIDrpSd & 2.2 & TxWntGrs & 5.3 & CrlyMsqt & 0.2 \\
\hline BrmWd & 0.1 & WdSedge & 3.2 & RbtTbaco & 0.3 & PrrBluet & 0.5 & PrCnflwr & 2.0 \\
\hline TxSage & 0.1 & DoveWeed & 0.1 & & & & & & \\
\hline
\end{tabular}




\begin{tabular}{|c|c|c|c|c|c|c|c|c|c|}
\hline \multicolumn{10}{|c|}{ Plant Communities } \\
\hline \multicolumn{10}{|c|}{7 - Oak-Ashe Juniper Woodland (light cover) } \\
\hline TxPrsmmn & 166.4 & AsheJunp & 1808.1 & ShRdOak & 55.3 & LvOak & 2403.8 & CdrElm & 36.0 \\
\hline Mesquite & 210.1 & Sotol & 30.5 & EvgSumac & 12.7 & GrnBriar & 27.1 & MtnGrape & 14.6 \\
\hline OfThrAn & 1.0 & KRBluStm & 31.4 & SiBluStm & 0.5 & SdOtsGrm & 0.2 & HryGrm & 0.1 \\
\hline TxCupGrs & 2.2 & LIBluStm & 5.8 & IndnGrs & 0.7 & TIDrpSd & 0.7 & TxWntGrs & 2.6 \\
\hline CrlyMsqt & 8.0 & BrmWd & 0.1 & WdSedge & 0.1 & RbtTbaco & 0.1 & PrCnflwr & 3.4 \\
\hline TxSage & 1.6 & DoveWeed & 0.2 & & & & & & \\
\hline \multicolumn{10}{|c|}{8 - Oak-Persimmon Woodland (dense cover) } \\
\hline NIHckbry & 358.0 & TxPrsmmn & 2215.9 & AsheJunp & 2160.9 & LvOak & 9246.3 & CdrElm & 1176.3 \\
\hline Mesquite & 219.6 & Sotol & 90.7 & EvgSumac & 38.0 & GrnBriar & 35.1 & MtnGrape & 20.8 \\
\hline OfThrAn & 0.3 & KRBluStm & 8.8 & TxCupGrs & 0.3 & TIDrpSd & 0.2 & TxWntGrs & 10.3 \\
\hline CrlyMsqt & 7.3 & BrmWd & 0.1 & WdSedge & 0.3 & RbtTbaco & 0.1 & PrCnflwr & 0.2 \\
\hline TxSage & 0.1 & DoveWeed & 0.4 & & & & & & \\
\hline \multicolumn{10}{|c|}{9 - Oak-Persimmon Woodland (moderate cover) } \\
\hline NIHckbry & 59.7 & TxPrsmmn & 991.5 & AsheJunp & 86.8 & ShRdOak & 1194.2 & LvOak & 3581.9 \\
\hline CdrElm & 156.0 & Sotol & 6.2 & EvgSumac & 16.5 & GrnBriar & 3.7 & MtnGrape & 52.1 \\
\hline OfThrAn & 0.6 & KRBluStm & 29.1 & SiBluStm & 3.6 & SdOtsGrm & 2.6 & HryGrm & 1.3 \\
\hline TxCupGrs & 0.7 & LIBluStm & 3.3 & TIDrpSd & 1.2 & TxWntGrs & 8.6 & CrlyMsqt & 1.6 \\
\hline BrmWd & 0.1 & WdSedge & 1.8 & RbtTbaco & 0.2 & PrrBluet & 0.1 & PrCnflwr & 4.5 \\
\hline DoveWeed & 0.1 & & & & & & & & \\
\hline \multicolumn{10}{|c|}{10 - Mixed Woodland } \\
\hline NIHckbry & 5154.7 & TxPrsmmn & 212.9 & AsheJunp & 3719.1 & ShRdOak & 1824.4 & LvOak & 3724.7 \\
\hline CdrElm & 900.2 & Sotol & 2.6 & EvgSumac & 25.3 & GrnBriar & 18.4 & MtnGrape & 125.0 \\
\hline OfThrAn & 0.1 & KRBluStm & 3.3 & SdOtsGrm & 0.1 & HryGrm & 0.3 & TxCupGrs & 0.6 \\
\hline LIBluStm & 1.8 & TIDrpSd & 1.0 & TxWntGrs & 0.1 & BrmWd & 0.1 & WdSedge & 1.6 \\
\hline PrrBluet & 0.8 & PrCnflwr & 0.1 & DoveWeed & 0.3 & & & & \\
\hline \multicolumn{10}{|c|}{11 - Ashe Juniper-Persimmon Savanna } \\
\hline TxPrsmmn & 443.5 & AsheJunp & 852.6 & CdrElm & 24.0 & Sotol & 29.0 & EvgSumac & 1.3 \\
\hline GrnBriar & 1.8 & MtnGrape & 4.2 & OfThrAn & 0.9 & KRBluStm & 0.1 & SiBluStm & 1.2 \\
\hline SdOtsGrm & 1.9 & HryGrm & 0.3 & BrmdaGrs & 0.3 & TxCupGrs & 0.6 & LIBluStm & 0.3 \\
\hline TIDrpSd & 0.1 & TxWntGrs & 0.6 & CrlyMsqt & 0.7 & BrmWd & 0.1 & WdSedge & 0.3 \\
\hline RbtTbaco & 0.1 & PrrBluet & 9.4 & PrCnflwr & 152.7 & TxSage & 0.3 & DoveWeed & 0.1 \\
\hline \multicolumn{10}{|c|}{12 - Oak Savanna } \\
\hline TxPrsmmn & 33.3 & AsheJunp & 147.0 & LvOak & 1106.7 & Sotol & 5.5 & OfThrAn & 0.4 \\
\hline KRBluStm & 42.2 & SiBluStm & 0.1 & SdOtsGrm & 2.2 & HryGrm & 2.1 & TxCupGrs & 2.0 \\
\hline LIBluStm & 7.2 & IndnGrs & 1.9 & TIDrpSd & 6.0 & CrlyMsqt & 3.9 & BrmWd & 0.1 \\
\hline WaSedge & 2.2 & RbtTbaco & 3.9 & PrrBluet & 0.6 & PrCnflwr & 4.7 & TxSage & 0.5 \\
\hline DoveWeed & 0.2 & & & & & & & & \\
\hline
\end{tabular}




\begin{tabular}{|c|c|c|c|c|c|c|c|c|c|}
\hline \multicolumn{10}{|c|}{ Plant Communities } \\
\hline \multicolumn{10}{|c|}{13 - Mesquite Savanna } \\
\hline Mesquite & 2912.4 & Sotol & 74.3 & OfThrAn & 1.3 & SiBluStm & 21.3 & LIBluStm & 1.8 \\
\hline TxWntGrs & 128.8 & CrlyMsqt & 3.8 & BrmWd & 0.1 & PrCnflwr & 25.6 & TxSage & 0.2 \\
\hline DoveWeed & 0.4 & & & & & & & & \\
\hline \multicolumn{10}{|c|}{14 - Shrubland } \\
\hline AsheJunp & 147.0 & LvOak & 119.0 & Sotol & 203.2 & MtnGrape & 52.1 & OfThrAn & 0.8 \\
\hline SdOtsGrm & 4.3 & HryGrm & 2.9 & LIBluStm & 9.1 & TIDrpSd & 1.3 & BrmWd & 0.6 \\
\hline WdSedge & 1.4 & RbtTbaco & 0.2 & PrCnflwr & 33.4 & TxSage & 0.1 & DoveWeed & 0.8 \\
\hline \multicolumn{10}{|c|}{15 - Bluestem Prairie } \\
\hline LvOak & 95.2 & CdrElm & 24.0 & Mesquite & 143.2 & Sotol & 9.4 & OfThrAn & 1.9 \\
\hline KRBluStm & 137.2 & SiBluStm & 7.0 & SdOtsGrm & 33.8 & HryGrm & 2.8 & TxCupGrs & 1.2 \\
\hline LIBluStm & 13.5 & TIDrpSd & 1.8 & TxWntGrs & 0.6 & CrlyMsqt & 0.8 & BrmWd & 0.1 \\
\hline WdSedge & 0.1 & RbtTbaco & 0.1 & PrrBluet & 1.4 & PrCnflwr & 6.7 & TxSage & 0.5 \\
\hline DoveWeed & 0.1 & & & & & & & & \\
\hline \multicolumn{10}{|c|}{16 - Shortgrass Plains } \\
\hline OfThrAn & 2.2 & KRBluStm & 1.1 & SdOtsGrm & 1.3 & HryGrm & 7.4 & TxCupGrs & 1.1 \\
\hline LIBluStm & 7.1 & TIDrpSd & 0.1 & TxWntGrs & 10.6 & CrlyMsqt & 13.6 & BrmWd & 0.3 \\
\hline WdSedge & 0.1 & RbtTbaco & 1.9 & PrrBluet & 0.8 & PrCnflwr & 12.8 & TxSage & 0.5 \\
\hline DoveWeed & 0.4 & & & & & & & & \\
\hline \multicolumn{10}{|c|}{17 - Improved Pasture } \\
\hline KRBluStm & 28.9 & BrmdaGrs & 132.0 & PrCnflwr & 2.1 & DoveWeed & 1.5 & & \\
\hline \multicolumn{10}{|c|}{18 - Cultivation } \\
\hline \multicolumn{10}{|c|}{ No Initial Biomass } \\
\hline \multicolumn{10}{|c|}{19 - Urban Lawn } \\
\hline TxPrsmmn & 33.3 & LvOak & 1190.0 & Mesquite & 32.4 & Sotol & 0.8 & BrmdaGrs & 132.0 \\
\hline PrCnflwr & 0.2 & & & & & & & & \\
\hline \multicolumn{10}{|c|}{20 - Urban Building } \\
\hline \multicolumn{10}{|c|}{ No Initial Biomass } \\
\hline \multicolumn{10}{|l|}{21 - Roads } \\
\hline GrnBriar & 6.9 & OfThrAn & 7.0 & KRBluStm & 92.4 & SiBluStm & 1.9 & SdOtsGrm & 1.8 \\
\hline HryGrm & 3.4 & BrmdaGrs & 46.9 & TxCupGrs & 1.6 & LIBluStm & 1.0 & TxWntGrs & 49.3 \\
\hline CrlyMsqt & 18.6 & BrmWd & 3.4 & RbtTbaco & 2.8 & PrrBluet & 1.8 & PrCnflwr & 4.2 \\
\hline TxSage & 1.6 & DoveWeed & 3.0 & & & & & & \\
\hline \multicolumn{10}{|c|}{22 - Rock/Bare } \\
\hline TxPrsmmn & 33.3 & AsheJunp & 147.0 & LvOak & 59.5 & Mesquite & 47.7 & Sotol & 7.8 \\
\hline EvgSumac & 6.3 & OfThrAn & 0.1 & SiBluStm & 0.1 & SdOtsGrm & 0.1 & HryGrm & 0.1 \\
\hline BrmdaGrs & 0.1 & LIBluStm & 0.1 & IndnGrs & 0.1 & BrmWd & 0.1 & RbtTbaco & 0.1 \\
\hline PrCnflwr & 0.1 & TxSage & 0.1 & & & & & & \\
\hline
\end{tabular}




\begin{tabular}{|c|c|c|c|c|c|c|c|c|c|}
\hline \multicolumn{10}{|c|}{ Plant Communities } \\
\hline \multicolumn{10}{|c|}{23 - Water's Edge } \\
\hline NIHckbry & 119.3 & CdrElm & 120.0 & GrnBriar & 29.6 & MtnGrape & 20.8 & KRBluStm & 77.1 \\
\hline SiBluStm & 49.4 & BrmdaGrs & 78.2 & TxCupGrs & 85.3 & SpMuhly & 46.3 & LIBluStm & 25.6 \\
\hline IndnGrs & 97.8 & BrmWd & 4.5 & PrrBluet & 24.4 & PrCnflwr & 27.7 & DoveWeed & 3.9 \\
\hline \multicolumn{10}{|c|}{24 - Water } \\
\hline \multicolumn{10}{|c|}{ No Initial Biomass } \\
\hline \multicolumn{10}{|c|}{25 - Channel } \\
\hline No Initial $\mathrm{B}$ & & & & & & & & & \\
\hline
\end{tabular}

(sheet 4 of 4 )

\section{Hydrologic model output}

Figures 17 and 18 show observed versus simulated flows for the Boerne and Selma Gages, respectively. Figure 19 demonstrates the 2-D output capacity of the modeling system.

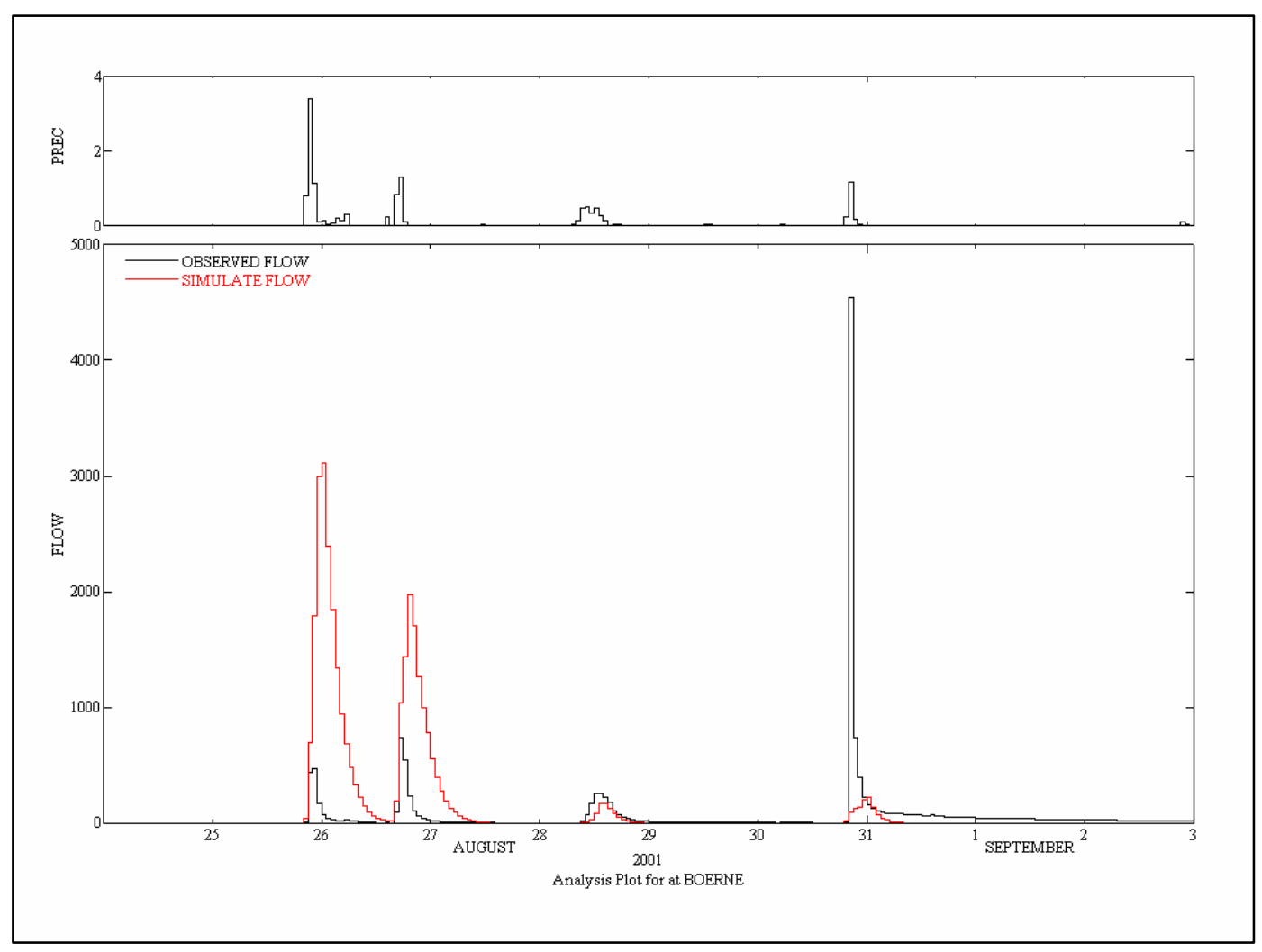

Figure 17. Flow (cfs) output at Boerne Gage. 


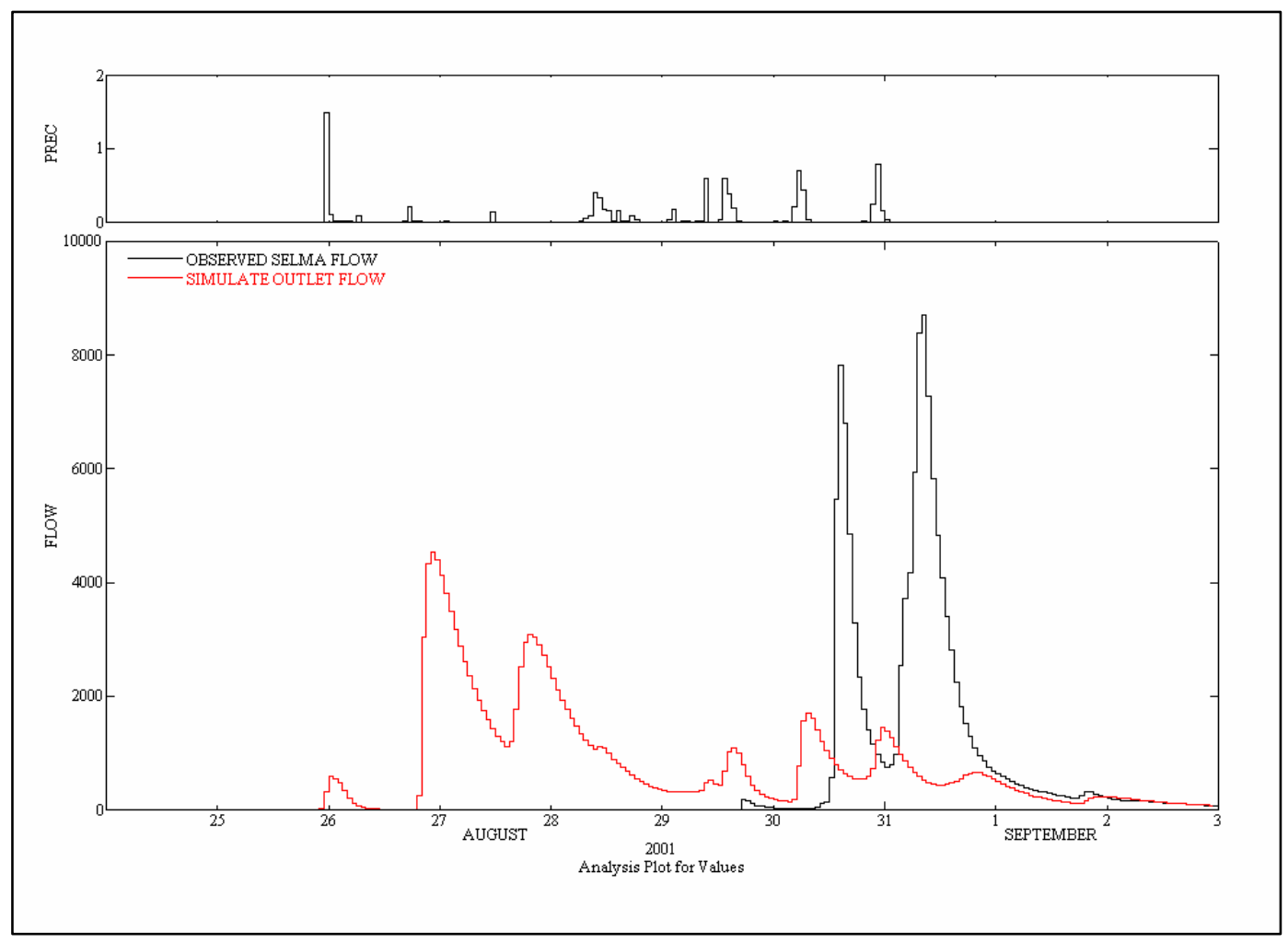

Figure 18. Flow (cfs) Output at Selma Gage (Watershed Outlet).

\section{Cibolo Creek Watershed}
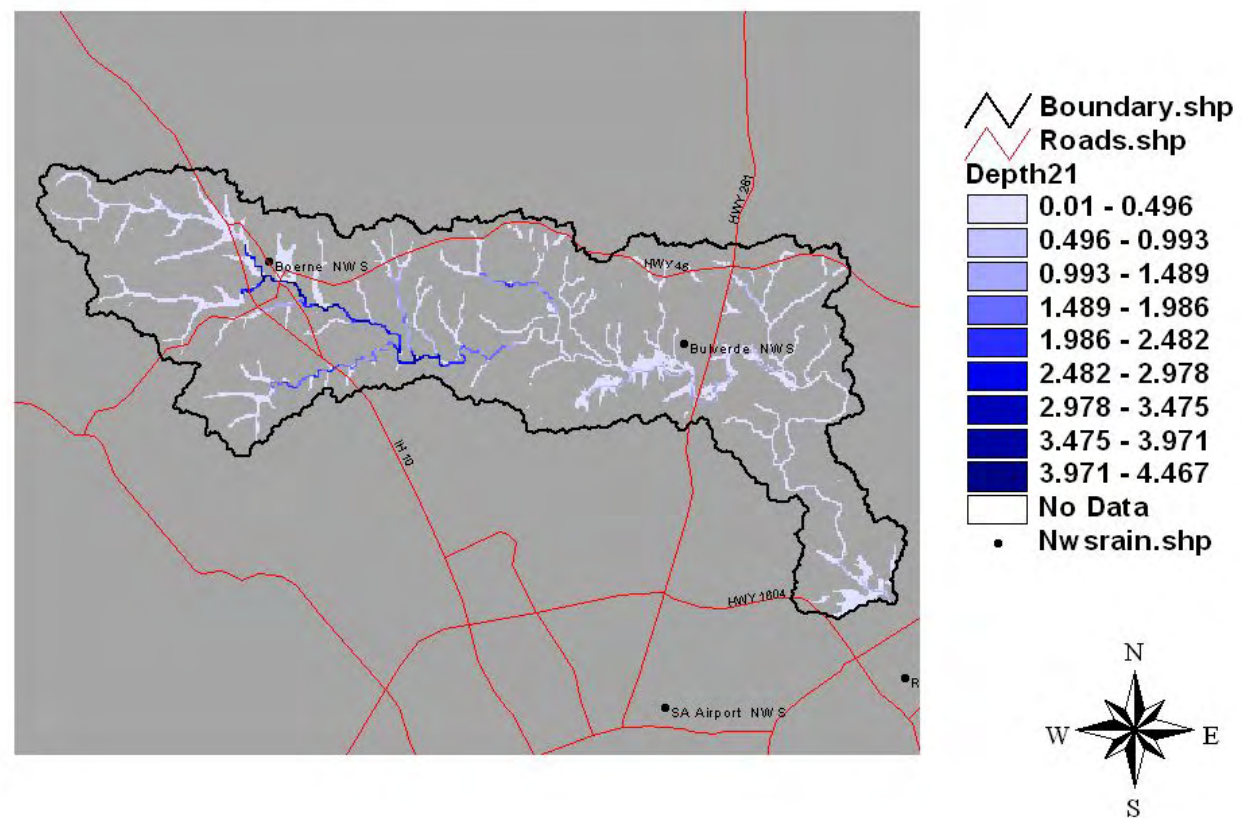

Figure 19. Surface and channel depths $(m)$ at 8/27/01 0:00. 


\section{EDYS model output}

The precipitation events handled by GSSHA all occurred within August of 2001. Therefore, any improvements in EDYS model performance with the linkage will only be seen after August. Table 8 illustrates differences in total soil moisture on 1 September 2001 between the linked run and an unlinked EDYS run for the same time period. Note the total soil moisture for the linked run is higher than the EDYS-only run. This would be expected due to the more sophisticated infiltration/percolation algorithm used by GSSHA, allowing greater retention times in the profile prior to percolating below the rooting zone of the plants. As a result, plant growth is slightly increased in the month following the precipitation events modeled by GSSHA (Table 9). For most communities, the increase is small ( $<1.0$ percent), but the increased production in the grassland communities is higher (from 3 to 23 percent). This greater increase arises from the ability of grasses and forbs to respond more quickly to increased moisture conditions, as compared to trees and shrubs.

Table 8. Total soil moisture on 1 September $(\mathrm{mm})$.

\begin{tabular}{|l|c|c|}
\hline Community Type & EDYS Only & $\begin{array}{l}\text { EDYS-GSSHA } \\
\text { Linked }\end{array}$ \\
\hline Ashe Juniper Woodland & 359.4 & 360.3 \\
\hline Ashe Juniper-Live Oak Woodland (very dense cover) & 72.9 & 74.3 \\
\hline Ashe Juniper-Live Oak Woodland (dense cover) & 182.7 & 183.7 \\
\hline Ashe Juniper-Live Oak Woodland (moderate cover) & 266.3 & 271.9 \\
\hline Ashe Juniper-Post Oak Woodland & 235.3 & 259.6 \\
\hline Oak-Ashe Juniper Woodland (moderate cover) & 75.6 & 82.1 \\
\hline Oak-Ashe Juniper Woodland (light cover) & 457.6 & 486.1 \\
\hline Oak-Persimmon Woodland (dense cover) & 77.4 & 101.1 \\
\hline Oak-Persimmon Woodland (moderate cover) & 486.3 & 495.0 \\
\hline Mixed Woodland & 80.1 & 91.4 \\
\hline Ashe Juniper-Persimmon Savanna & 367.5 & 518.5 \\
\hline Oak Savanna & 571.9 & 575.7 \\
\hline Mesquite Savanna & 223.7 & 337.2 \\
\hline Shrubland & 367.5 & 422.9 \\
\hline Bluestem Prairie & 227.8 & 332.6 \\
\hline Shortgrass Plains & 513.7 & 604.3 \\
\hline Improved Pasture & 499.3 & 559.3 \\
\hline Cultivation & 330.9 & 354.8 \\
\hline Urban Lawn & 408.4 & 440.6 \\
\hline Water's Edge & 394.2 & 438.3 \\
\hline
\end{tabular}


Table 9. Total aboveground biomass on 30 September $\left(\mathrm{g} / \mathrm{m}^{2}\right)$.

\begin{tabular}{|l|c|c|}
\hline Community Type & EDYS Only & $\begin{array}{l}\text { EDYS-GSSHA } \\
\text { Linked }\end{array}$ \\
\hline Ashe Juniper Woodland & 9714.22 & 9790.44 \\
\hline Ashe Juniper-Live Oak Woodland (very dense cover) & 16624.62 & 16650.66 \\
\hline Ashe Juniper-Live Oak Woodland (dense cover) & 12013.50 & 12063.44 \\
\hline Ashe Juniper-Live Oak Woodland (moderate cover) & 8681.51 & 8734.18 \\
\hline Ashe Juniper-Post Oak Woodland & 5820.61 & 5918.95 \\
\hline Oak-Ashe Juniper Woodland (moderate cover) & 10297.90 & 10336.16 \\
\hline Oak-Ashe Juniper Woodland (light cover) & 4876.58 & 4877.33 \\
\hline Oak-Persimmon Woodland (dense cover) & 15223.35 & 15246.38 \\
\hline Oak-Persimmon Woodland (moderate cover) & 6248.30 & 6248.34 \\
\hline Mixed Woodland & 15563.26 & 15598.76 \\
\hline Ashe Juniper-Persimmon Savanna & 1911.52 & 1972.53 \\
\hline Oak Savanna & 1434.29 & 1434.27 \\
\hline Mesquite Savanna & 3313.95 & 3386.67 \\
\hline Shrubland & 844.07 & 854.19 \\
\hline Bluestem Prairie & 749.86 & 922.13 \\
\hline Shortgrass Plains & 328.79 & 339.77 \\
\hline Improved Pasture & 652.04 & 709.30 \\
\hline Cultivation & 12.26 & 19.58 \\
\hline Urban Lawn & 1697.10 & 1697.06 \\
\hline Water's Edge & 1101.03 & 1108.08 \\
\hline
\end{tabular}




\section{Conclusions and Recommendations}

The purpose of this development activity was to work out the mechanism by which GSSHA and EDYS could manually exchange data and to evaluate the need for more complex data exchanges between the two modeling systems. As has been mentioned previously, the only data exchanged between the two models was soil moisture data. It is anticipated that in the future, data layers such as roughness, hydraulic conductivity, nutrient masses, etc. can be exchanged in order to further enhance the nutrient sub-modules in addition to allowing the user to model dynamic land use changes due to either man-made scenarios (i.e., urban growth or military training) or due to natural scenarios (i.e., forest fires). As the data exchanges become more complex, detailed long-term simulations will be achievable whereby small restoration features can be evaluated within the context of the whole system.

Conclusions drawn during this study seem to indicate that more work is needed in calibrating the hydraulics and hydrology modules in order to better compare to the Boerne and Selma Gages. As part of this investigation, better rainfall estimates need to be made and a geologic investigation needs to be done such that channel and overland transmission losses can be better estimated.

Finally, it is the recommendation of the authors that further enhancements to the manual linkage can and should proceed in order to provide the nutrient sub-modules with the ability to have plant uptake and biomass loading. In addition, the enhancements will allow for more accurate water budget computations and for dynamic soil and land use parameter estimations over long-term simulation periods. 


\section{References}

Barrow, N. J., and T. C. Shaw. 1975. The slow reactions between soil and anions, 2. Effect of time and temperature on the decrease in phosphate concentration in soil solution. Soil Sci. 119:167-177.

Beven, K. J . 1979. A sensitivity analysis of the Penman-Monteith actual evapotranspiration estimates. J. Hydrol. 44:169-190.

Childress, W. M., and T. McLendon. 1999. Simulation of multi-scale environmental impacts using the EDYS model. Hydrological Science and Technology 15:257269.

Childress, W. M., C. L. Coldren, and T. McLendon. 2002. Applying a complex, general ecosystem model (EDYS) in large-scale land management. Ecological Modelling 153:97-108.

Childress, W. M., D. L. Price, C. L. Coldren, and T. McLendon. 1999b. A functional description of the Ecological DYnamics Simulation (EDYS) model, with applications for Army and other federal land managers. USACERL Technical Report 99. Champaign, IL: U.S. Army Engineer Research and Development Center.

Childress, W. M., T. McLendon, and D. L. Price. 1999a. A multiscale ecological model for allocation of training activities on US Army installations. In J effrey M. Klopatek and Robert H. Gardner (eds.) Landscape Ecological Analysis: Issues, Challenges, and Ideas. Ecological Studies Series. Chapter 6. NewYork: SpringerVerlag, 80-108.

Deardorff, J. W. 1978. Efficient prediction of ground surface temperature and moisture, with inclusion of a layer of vegetation. J . Geophys. Res. 83:1889-1903.

Dickinson, R. E., A. Henderson-Sellers, P. J. Kennedy, and M. F. Wilson. 1986. Biosphere-Atmosphere Transfer Scheme (BATS) for the NCAR Community Climate Model, National Center for Atmospheric Research, NCAR/TN-275+STR.

Downer, C. W., and F. L. Ogden. 2002. GSSHA user's manual. Vicksburg, MS: U.S. Army Engineer Research and Development Center.

. 2003. Prediction of runoff and soil moistures at the watershed scale- Effects of model complexity and parameter assignment. Water Resources Research 39(3):1.1-1.13.

Green, W. H., and G. A. Ampt. 1911. Studies on soil physics, 1: The flow of air and water through soils. J . Agric. Sci. 4(1), 1-24.

Godwin, D. C., C. A. J ones, J . T. Ritchie, P. L. G. Vlek, and L. G. Youngdahl. 1984. The water and nitrogen components of the CERES models. In Proc. Intl. Symp. on Minimum Data Sets for Agrotechnology Transfer. Patancheru, India: Intl. Crops Research Institute for the Semi-Arid Tropics, 95-100. 
Gray, D. M. 1970. Handbook on the principles of hydrology. Port Washington, NY: National Research Council of Canada, Water Information Center Inc., Water Research Building, Manhasset Isle.

J ohnson, B. E. 1997. Development of a storm event based two-dimensional upland erosion model, Ph.D. Dissertation, Dept of Civil Engineering, Colorado State University, Fort Collins, CO 80523.

J ohnson, B. E., and T. K. Gerald. FY05 Nutrient Sub-Module (NSM) SWWRP Formulations, in preparation, Technical Report. Vicksburg, MS: U.S. Army Engineer Research and Development Center.

J ones, C. A., C. V. Cole, A. N. Sharpley, and J . R. Williams. 1984. A simplified soil and plant phosphorus model. I. Documentation. Soil Sci. Soc. Am. J . 48:800-805.

J ulien, P. Y., B. Saghafian, and F. L. Ogden. 1995. Raster-based hydrologic modeling of spatially-varied surface runoff. Water Resources Bulletin, AWRA, 31(3):523-536.

Kilinc, M., and E. V. Richardson. 1973. Mechanics of soil erosion from overland flow generated by simulated rainfall. Hydrology Papers No. 63, Fort Collins, CO: Colorado State University.

McLendon, T., C. L. Coldren, and W. M. Childress. 2001. Application of the EDYS model to a training area landscape at Fort Hood, Texas. Technical Report SMI-ES023. Fort Collins, CO: Shepherd Miller, Inc. . 2002. Application of the EDYS model to a training area landscape at Camps Bullis and Stanley, Texas. Technical Report SMI-ES-028. Fort Collins, CO: Shepherd Miller, Inc.

McLendon, T., W. M. Childress, D. L. Price, and T. Atwood. 1999. Ecological Dynamics Simulation Model (EDYS). Proceedings of the Sixth National Watershed Conference, Austin, TS. 231-241.

Monteith, J . L. 1965. Evaporation and environment. Symp. Soc. Exp. Biol. XIX, 205-234. . 1981. Evaporation and surface temperature. Q.J . R. Meteorol. Soc. 107:1-27.

Munns, D. N., and R. L. Fox. 1976. The slow reaction which continues after phosphate adsorption: Kinetics and equilibrium in some tropical soils. Soil Sci. Plant Anal. 3:493-504.

Ogden, F. L., and B. Saghafian. 1997. Green and Ampt infiltration with redistribution. J. Irrigation and Drainage Engineering, ASCE 123(5):386-393.

Pinder, G. F., and J . D. Bredehoeft. 1968. Application of a digital computer for aquifer elevations. Wat. Resour. Res. 4:1069-1093.

Price, D. L., T. McLendon, and C. Coldren. 2004. Application of an ecological model for the Cibolo Creek Watershed. Water Quality Technical Notes Collection ERDC WQTN-CS-04. Vicksburg, MS: U.S. Army Engineer Research and Development Center. 
Rajan, S. S. S., and R. L. Fox. 1972. Phosphate adsorption by soils, 1. Influence of time and ionic environment on phosphate adsorption. Commun. Soil. Sci. Plant Anal. 3:493-504.

Reddy, K. R., R. Khaleel, M. R. Overcash, and P. W. Westerman. 1979. A non-point source model for land areas receiving animal wastes: II. Ammonia volatilization. Trans. ASAE 22:1398-1404.

Renard, K. G., G. R. Foster, G. A. Weesies, and J . P. Porter. 1991. RUSLE - Revised Universal Soil Loss Equation. J. Soil Water Cons. 46:30-33.

Saxton, K. E., W. J . Rawls, J . S. Romberger, and R. I. Papendick. 1986. Estimating generalized soil-water characteristics from texture. Soil Sci. Soc. Am. J . 50:10311036.

Sharpley, A. N. 1982. A prediction of the water extractable phosphorus content of soil following a phosphorus addition. J . Environ. Qual. 11:166-170.

Sharpley, A. N., and J . K. Syers. 1979. Phosphorus inputs into a stream draining an agricultural watershed: II. Amounts and relative significance of runoff types. Water, Air, and Pollution 11:417-428.

Tannehill, J . C., D. A. Anderson, and R. H. Pletcher. 1977. Computational fluid mechanics and heat transfer, 2nd edition. Washington, DC: Taylor and Francis.

Trescott, P. C., and S. P. Larson. 1977. Comparison of iterative methods of solving twodimensional groundwater flow equations. Wat. Resourc. Res. 13(1):125-136.

U.S. Soil Conservation Service (USSCS). 1975. Soil taxonomy - A basic system of soil classification for making and interpreting soil surveys. Agriculture Handbook No. 436. U.S. Department of Agriculture. Washington, DC: U.S. Government Printing Office.

Yang, C. T. 1973. Incipient motion and sediment transport. J . Hydr. Div. ASCE, 99(HY10):1679-1704. 


\section{Appendix A: Soil Series Characteristics}

\section{Anhalt Clay}

\begin{tabular}{|l|l|l|l|l|l|l|}
\hline Layer Name & $\begin{array}{l}\text { Depth } \\
(\mathbf{m m})\end{array}$ & $\begin{array}{l}\text { Wilting Point } \\
(\%)\end{array}$ & $\begin{array}{l}\text { Field Capacity } \\
(\%)\end{array}$ & $\begin{array}{l}\text { Saturation } \\
(\%)\end{array}$ & $\begin{array}{l}\text { Organic Matter } \\
\left(\mathbf{g} / \mathbf{m}^{2}\right)\end{array}$ & $\begin{array}{l}\text { Nitrogen } \\
\left(\mathrm{g} / \mathbf{m}^{2}\right)\end{array}$ \\
\hline Ap & 25 & 23.80 & 40.40 & 53.20 & 1625.00 & 131.30 \\
\hline Ap & 25 & 23.80 & 40.40 & 53.20 & 1397.50 & 112.92 \\
\hline Ap & 25 & 23.80 & 40.40 & 53.20 & 1235.00 & 99.79 \\
\hline A1 & 25 & 23.80 & 40.40 & 53.20 & 1105.00 & 89.28 \\
\hline A1 & 25 & 23.80 & 40.40 & 53.20 & 975.00 & 78.78 \\
\hline A1 & 50 & 23.80 & 40.40 & 53.20 & 1755.00 & 141.80 \\
\hline Bss1 & 150 & 39.00 & 52.80 & 56.00 & 4500.00 & 363.60 \\
\hline Bss1 & 150 & 39.00 & 52.80 & 56.00 & 3750.00 & 303.00 \\
\hline Bss1 & 125 & 39.00 & 52.80 & 56.00 & 1562.50 & 126.25 \\
\hline Bss1 & 125 & 39.00 & 52.80 & 56.00 & 1406.25 & 113.63 \\
\hline $\mathrm{Cr}$ & 75 & 0.80 & 1.10 & 1.10 & 0.34 & 0.03 \\
\hline $\mathrm{Cr}$ & 75 & 0.80 & 1.10 & 1.10 & 0.17 & 0.01 \\
\hline $\mathrm{Cr}$ & 125 & 0.80 & 1.10 & 1.10 & 0.28 & 0.02 \\
\hline
\end{tabular}

\section{Brackett-Real Association}

\begin{tabular}{|l|l|l|l|l|l|l|}
\hline Layer Name & $\begin{array}{l}\text { Depth } \\
(\mathrm{mm})\end{array}$ & $\begin{array}{l}\text { Wilting Point } \\
(\%)\end{array}$ & $\begin{array}{l}\text { Field Capacity } \\
(\%)\end{array}$ & $\begin{array}{l}\text { Saturation } \\
(\%)\end{array}$ & $\begin{array}{l}\text { Organic Matter } \\
\left(\mathrm{g} / \mathrm{m}^{2}\right)\end{array}$ & $\begin{array}{l}\text { Nitrogen } \\
\left(\mathrm{g} / \mathrm{m}^{2}\right)\end{array}$ \\
\hline A & 25 & 19.47 & 30.37 & 49.49 & 840.00 & 84.01 \\
\hline A & 25 & 19.47 & 30.37 & 49.49 & 805.00 & 80.51 \\
\hline A & 50 & 19.47 & 30.37 & 49.49 & 1190.00 & 119.01 \\
\hline A & 50 & 19.47 & 30.37 & 49.49 & 1120.00 & 112.01 \\
\hline Bw & 50 & 12.52 & 26.25 & 46.90 & 1033.00 & 103.32 \\
\hline Bw & 50 & 12.52 & 26.25 & 46.90 & 962.00 & 96.20 \\
\hline Bw & 50 & 12.52 & 26.25 & 46.90 & 819.00 & 81.95 \\
\hline Bw & 50 & 12.52 & 26.25 & 46.90 & 748.00 & 74.82 \\
\hline C & 100 & 25.40 & 39.82 & 52.62 & 1425.00 & 142.51 \\
\hline C & 100 & 25.40 & 39.82 & 52.62 & 1275.00 & 127.51 \\
\hline C & 300 & 25.40 & 39.82 & 52.62 & 3375.00 & 337.51 \\
\hline C & 300 & 25.40 & 39.82 & 52.62 & 2925.00 & 292.51 \\
\hline C & 400 & 25.40 & 39.82 & 52.62 & 3300.00 & 330.01 \\
\hline
\end{tabular}


Brackett-Rock Outcrop-Comfort Complex

\begin{tabular}{|l|l|l|l|l|l|l|}
\hline Layer Name & $\begin{array}{l}\text { Depth } \\
(\mathrm{mm})\end{array}$ & $\begin{array}{l}\text { Wilting Point } \\
(\%)\end{array}$ & $\begin{array}{l}\text { Field Capacity } \\
(\%)\end{array}$ & $\begin{array}{l}\text { Saturation } \\
(\%)\end{array}$ & $\begin{array}{l}\text { Organic Matter } \\
\left(\mathrm{g} / \mathrm{m}^{2}\right)\end{array}$ & $\begin{array}{l}\text { Nitrogen } \\
\left(\mathrm{g} / \mathrm{m}^{2}\right)\end{array}$ \\
\hline $\mathrm{A}$ & 25 & 14.77 & 26.65 & 47.63 & 840.00 & 84.01 \\
\hline $\mathrm{A}$ & 25 & 14.77 & 26.65 & 47.63 & 805.00 & 80.51 \\
\hline $\mathrm{A}$ & 50 & 14.77 & 26.65 & 47.63 & 1190.00 & 119.01 \\
\hline $\mathrm{A}$ & 50 & 14.77 & 26.65 & 47.63 & 1120.00 & 112.01 \\
\hline $\mathrm{Bw}$ & 50 & 16.95 & 29.65 & 49.15 & 1033.00 & 103.32 \\
\hline $\mathrm{Bw}$ & 50 & 16.95 & 29.65 & 49.15 & 962.00 & 96.20 \\
\hline $\mathrm{Bw}$ & 50 & 16.95 & 29.65 & 49.15 & 819.00 & 81.95 \\
\hline $\mathrm{Bw}$ & 50 & 16.95 & 29.65 & 49.15 & 748.00 & 74.82 \\
\hline $\mathrm{Cr}$ & 100 & 17.06 & 28.45 & 48.64 & 1354.00 & 135.39 \\
\hline $\mathrm{Cr}$ & 100 & 17.06 & 28.45 & 48.64 & 1211.00 & 121.14 \\
\hline $\mathrm{Cr}$ & 200 & 17.06 & 28.45 & 48.64 & 2138.00 & 213.76 \\
\hline $\mathrm{Cr}$ & 350 & 17.06 & 28.45 & 48.64 & 3242.00 & 324.20 \\
\hline $\mathrm{Cr}$ & 450 & 17.06 & 28.45 & 48.64 & 3527.00 & 352.70 \\
\hline
\end{tabular}

Comfort-Rock Outcrop Complex

\begin{tabular}{|l|l|l|l|l|l|l|}
\hline Layer Name & $\begin{array}{l}\text { Depth } \\
(\mathrm{mm})\end{array}$ & $\begin{array}{l}\text { Wilting Point } \\
(\%)\end{array}$ & $\begin{array}{l}\text { Field Capacity } \\
(\%)\end{array}$ & $\begin{array}{l}\text { Saturation } \\
(\%)\end{array}$ & $\begin{array}{l}\text { Organic Matter } \\
\left(\mathrm{g} / \mathrm{m}^{2}\right)\end{array}$ & $\begin{array}{l}\text { Nitrogen } \\
\left(\mathrm{g} / \mathrm{m}^{2}\right)\end{array}$ \\
\hline $\mathrm{A}$ & 25 & 19.46 & 31.29 & 49.86 & 2188.00 & 196.89 \\
\hline $\mathrm{A}$ & 25 & 19.46 & 31.29 & 49.86 & 2031.00 & 182.82 \\
\hline $\mathrm{A}$ & 50 & 19.46 & 31.29 & 49.86 & 3438.00 & 309.39 \\
\hline $\mathrm{A}$ & 50 & 19.46 & 31.29 & 49.86 & 3125.00 & 281.26 \\
\hline $\mathrm{Bt}$ & 25 & 24.06 & 31.07 & 50.30 & 1530.00 & 137.71 \\
\hline $\mathrm{Bt}$ & 50 & 24.06 & 31.07 & 50.30 & 2933.00 & 263.94 \\
\hline $\mathrm{Bt}$ & 50 & 24.06 & 31.07 & 50.30 & 2805.00 & 252.46 \\
\hline $\mathrm{Bt}$ & 50 & 24.06 & 31.07 & 50.30 & 2678.00 & 240.99 \\
\hline $\mathrm{R}$ & 25 & 1.24 & 1.31 & 1.50 & 0 & 0.04 \\
\hline $\mathrm{R}$ & 25 & 1.24 & 1.31 & 1.50 & 0 & 0.04 \\
\hline $\mathrm{R}$ & 25 & 1.00 & 1.00 & 1.00 & 0 & 0.01 \\
\hline $\mathrm{R}$ & 25 & 1.00 & 1.00 & 1.00 & 0 & 0.01 \\
\hline $\mathrm{R}$ & 25 & 1.00 & 1.00 & 1.00 & 0 & 0.01 \\
\hline
\end{tabular}




\section{Denton Silty Clay}

\begin{tabular}{|l|l|l|l|l|l|c|}
\hline Layer Name & $\begin{array}{l}\text { Depth } \\
(\mathrm{mm})\end{array}$ & $\begin{array}{l}\text { Wilting Point } \\
(\%)\end{array}$ & $\begin{array}{l}\text { Field Capacity } \\
(\%)\end{array}$ & $\begin{array}{l}\text { Saturation } \\
(\%)\end{array}$ & $\begin{array}{l}\text { Organic Matter } \\
\left(\mathrm{g} / \mathrm{m}^{2}\right)\end{array}$ & $\begin{array}{l}\text { Nitrogen } \\
\left(\mathrm{g} / \mathrm{m}^{2}\right)\end{array}$ \\
\hline $\mathrm{Ap}$ & 25 & 19.42 & 36.12 & 51.81 & 938.00 & 93.76 \\
\hline $\mathrm{Ap}$ & 50 & 19.42 & 36.12 & 51.81 & 1750.00 & 175.01 \\
\hline $\mathrm{Ap}$ & 50 & 19.42 & 36.12 & 51.81 & 1563.00 & 156.26 \\
\hline $\mathrm{A}$ & 75 & 25.66 & 41.33 & 53.20 & 2063.00 & 206.26 \\
\hline $\mathrm{A}$ & 75 & 25.66 & 41.33 & 53.20 & 1875.00 & 187.51 \\
\hline $\mathrm{Bw}$ & 750 & 25.51 & 40.44 & 52.84 & 1877.00 & 187.66 \\
\hline $\mathrm{Bw}$ & 125 & 25.51 & 40.44 & 52.84 & 2606.00 & 260.64 \\
\hline Bw & 125 & 25.51 & 40.44 & 52.84 & 2085.00 & 208.51 \\
\hline $2 \mathrm{Bk}$ & 125 & 20.54 & 34.51 & 51.03 & 1906.00 & 190.64 \\
\hline $2 \mathrm{Bk}$ & 125 & 20.54 & 34.51 & 51.03 & 1334.00 & 133.45 \\
\hline $2 \mathrm{CBk}$ & 50 & 19.45 & 32.63 & 50.36 & 381.00 & 38.14 \\
\hline $2 \mathrm{CBk}$ & 75 & 19.45 & 32.63 & 50.36 & 229.00 & 22.89 \\
\hline $2 \mathrm{R}$ & 525 & 1.00 & 1.00 & 1.00 & 0 & 0.01 \\
\hline
\end{tabular}

\section{Doss-Brackett Association}

\begin{tabular}{|l|l|l|l|l|l|c|}
\hline Layer Name & $\begin{array}{l}\text { Depth } \\
(\mathrm{mm})\end{array}$ & $\begin{array}{l}\text { Wilting Point } \\
(\%)\end{array}$ & $\begin{array}{l}\text { Field Capacity } \\
(\%)\end{array}$ & $\begin{array}{l}\text { Saturation } \\
(\%)\end{array}$ & $\begin{array}{l}\text { Organic Matter } \\
\left(\mathrm{g} / \mathrm{m}^{2}\right)\end{array}$ & $\begin{array}{l}\text { Nitrogen } \\
\left(\mathrm{g} / \mathrm{m}^{2}\right)\end{array}$ \\
\hline $\mathrm{A}$ & 25 & 19.47 & 30.37 & 49.49 & 840.00 & 84.01 \\
\hline $\mathrm{A}$ & 25 & 19.47 & 30.37 & 49.49 & 805.00 & 80.51 \\
\hline $\mathrm{A}$ & 50 & 19.47 & 30.37 & 49.49 & 1190.00 & 119.01 \\
\hline $\mathrm{A}$ & 50 & 19.47 & 30.37 & 49.49 & 1120.00 & 112.01 \\
\hline $\mathrm{Bk}$ & 50 & 14.62 & 27.80 & 48.14 & 1033.00 & 103.32 \\
\hline $\mathrm{Bk}$ & 75 & 14.62 & 27.80 & 48.14 & 1443.00 & 144.29 \\
\hline $\mathrm{Bk}$ & 75 & 14.62 & 27.80 & 48.14 & 1229.00 & 122.92 \\
\hline $\mathrm{Cr}$ & 100 & 22.18 & 35.27 & 51.25 & 825.00 & 82.51 \\
\hline $\mathrm{Cr}$ & 200 & 22.18 & 35.27 & 51.25 & 2850.00 & 285.01 \\
\hline $\mathrm{Cr}$ & 200 & 22.18 & 35.27 & 51.25 & 2550.00 & 255.01 \\
\hline $\mathrm{Cr}$ & 200 & 22.18 & 35.27 & 51.25 & 2250.00 & 225.01 \\
\hline $\mathrm{Cr}$ & 250 & 16.84 & 30.89 & 49.66 & 2438.00 & 243.76 \\
\hline $\mathrm{Cr}$ & 250 & 16.84 & 30.89 & 49.66 & 2063.00 & 206.26 \\
\hline
\end{tabular}




\section{Eckrant-Rock Outcrop Complex}

\begin{tabular}{|l|l|l|l|l|l|l|}
\hline Layer Name & $\begin{array}{l}\text { Depth } \\
(\mathrm{mm})\end{array}$ & $\begin{array}{l}\text { Wilting Point } \\
(\%)\end{array}$ & $\begin{array}{l}\text { Field Capacity } \\
(\%)\end{array}$ & $\begin{array}{l}\text { Saturation } \\
(\%)\end{array}$ & $\begin{array}{l}\text { Organic Matter } \\
\left(\mathrm{g} / \mathrm{m}^{2}\right)\end{array}$ & $\begin{array}{l}\text { Nitrogen } \\
\left(\mathrm{g} / \mathrm{m}^{2}\right)\end{array}$ \\
\hline A1 & 25 & 30.42 & 41.56 & 52.87 & 3988.00 & 279.14 \\
\hline A1 & 50 & 30.42 & 41.56 & 52.87 & 7250.00 & 507.51 \\
\hline A1 & 50 & 30.42 & 41.56 & 52.87 & 6525.00 & 456.76 \\
\hline A1 & 50 & 30.42 & 41.56 & 52.87 & 5800.00 & 406.01 \\
\hline A1 & 75 & 30.42 & 41.56 & 52.87 & 7613.00 & 532.89 \\
\hline A2 & 75 & 21.94 & 32.56 & 50.31 & 6638.00 & 464.64 \\
\hline A2 & 75 & 21.94 & 32.56 & 50.31 & 5531.00 & 387.20 \\
\hline A2 & 100 & 21.94 & 32.56 & 50.31 & 5900.00 & 413.01 \\
\hline A2 & 100 & 21.94 & 32.56 & 50.31 & 4425.00 & 309.76 \\
\hline A2 & 100 & 21.94 & 32.56 & 50.31 & 2950.00 & 206.51 \\
\hline R & 125 & 1.22 & 1.33 & 1.50 & 2.00 & 0.14 \\
\hline R & 250 & 1.00 & 1.00 & 1.00 & 0 & 0.01 \\
\hline R & 250 & 1.00 & 1.00 & 1.00 & 0 & 0.01 \\
\hline
\end{tabular}

\section{Krum Silty Clay}

\begin{tabular}{|l|l|l|l|l|l|l|}
\hline Layer Name & $\begin{array}{l}\text { Depth } \\
(\mathrm{mm})\end{array}$ & $\begin{array}{l}\text { Wilting Point } \\
(\%)\end{array}$ & $\begin{array}{l}\text { Field Capacity } \\
(\%)\end{array}$ & $\begin{array}{l}\text { Saturation } \\
(\%)\end{array}$ & $\begin{array}{l}\text { Organic Matter } \\
\left(\mathrm{g} / \mathrm{m}^{2}\right)\end{array}$ & $\begin{array}{l}\text { Nitrogen } \\
\left(\mathrm{g} / \mathrm{m}^{2}\right)\end{array}$ \\
\hline Ap & 25 & 23.80 & 40.40 & 53.20 & 1087.50 & 87.87 \\
\hline Ap & 50 & 23.80 & 40.40 & 53.20 & 2030.00 & 164.02 \\
\hline Ap & 75 & 23.80 & 40.40 & 53.20 & 2610.00 & 210.89 \\
\hline A & 75 & 23.80 & 40.40 & 53.20 & 2175.00 & 175.74 \\
\hline A & 75 & 23.80 & 40.40 & 53.20 & 1957.50 & 158.17 \\
\hline A & 100 & 23.80 & 40.40 & 53.20 & 2320.00 & 187.46 \\
\hline Bw & 175 & 33.40 & 46.50 & 54.10 & 3128.13 & 252.75 \\
\hline Bw & 200 & 33.40 & 46.50 & 54.10 & 2750.00 & 222.20 \\
\hline Bw & 200 & 33.40 & 46.50 & 54.10 & 2475.00 & 199.98 \\
\hline Bw & 200 & 33.40 & 46.50 & 54.10 & 2200.00 & 177.76 \\
\hline Bk1 & 125 & 28.30 & 43.80 & 53.80 & 1246.88 & 100.75 \\
\hline Bk1 & 125 & 28.30 & 43.80 & 53.80 & 1068.75 & 86.36 \\
\hline Bk2 & 125 & 28.30 & 43.80 & 53.80 & 890.63 & 71.96 \\
\hline
\end{tabular}




\section{Lewisville Silty Clay}

\begin{tabular}{|l|l|l|l|l|l|l|}
\hline Layer Name & $\begin{array}{l}\text { Depth } \\
(\mathrm{mm})\end{array}$ & $\begin{array}{l}\text { Wilting Point } \\
(\%)\end{array}$ & $\begin{array}{l}\text { Field Capacity } \\
(\%)\end{array}$ & $\begin{array}{l}\text { Saturation } \\
(\%)\end{array}$ & $\begin{array}{l}\text { Organic Matter } \\
\left(\mathrm{g} / \mathrm{m}^{2}\right)\end{array}$ & $\begin{array}{l}\text { Nitrogen } \\
\left(\mathrm{g} / \mathrm{m}^{2}\right)\end{array}$ \\
\hline Ap & 25 & 25.80 & 42.50 & 53.90 & 975.00 & 78.78 \\
\hline Ap & 50 & 25.80 & 42.50 & 53.90 & 1820.00 & 147.06 \\
\hline Ap & 50 & 25.80 & 42.50 & 53.90 & 1625.00 & 131.30 \\
\hline A & 50 & 25.80 & 42.50 & 53.90 & 1495.00 & 120.80 \\
\hline A & 50 & 25.80 & 42.50 & 53.90 & 1300.00 & 105.04 \\
\hline A & 100 & 25.80 & 42.50 & 53.90 & 2340.00 & 189.07 \\
\hline A & 100 & 25.80 & 42.50 & 53.90 & 1950.00 & 157.56 \\
\hline Bk1 & 125 & 25.70 & 41.30 & 53.20 & 2153.00 & 173.97 \\
\hline Bk1 & 175 & 25.70 & 41.30 & 53.20 & 2551.00 & 206.09 \\
\hline Bk1 & 175 & 25.70 & 41.30 & 53.20 & 2319.00 & 187.36 \\
\hline Bk2 & 125 & 19.40 & 36.50 & 52.00 & 1400.00 & 113.12 \\
\hline Bk2 & 250 & 19.40 & 36.50 & 52.00 & 2100.00 & 169.68 \\
\hline Bk2 & 250 & 19.40 & 36.50 & 52.00 & 1400.00 & 113.12 \\
\hline
\end{tabular}




\section{Appendix B: Plant Parameters}

Table B1. Mature allocation matrix.

\begin{tabular}{|l|l|l|l|l|l|l|}
\hline Species & CRoot & FRoot & Trunk & Stems & Leaves & Seeds \\
\hline NIHckbry & 0.20 & 0.10 & 0.50 & 0.15 & 0.05 & 0.00 \\
\hline TxPrsmmn & 0.22 & 0.11 & 0.45 & 0.15 & 0.07 & 0.00 \\
\hline AsheJunp & 0.25 & 0.09 & 0.34 & 0.21 & 0.11 & 0.00 \\
\hline ShRdOak & 0.26 & 0.14 & 0.31 & 0.25 & 0.04 & 0.00 \\
\hline LvOak & 0.25 & 0.13 & 0.31 & 0.27 & 0.04 & 0.00 \\
\hline CdrEIm & 0.18 & 0.09 & 0.48 & 0.20 & 0.05 & 0.00 \\
\hline Mesquite & 0.32 & 0.15 & 0.28 & 0.19 & 0.06 & 0.00 \\
\hline Sotol & 0.44 & 0.29 & 0.08 & 0.03 & 0.16 & 0.00 \\
\hline EvgSumac & 0.60 & 0.12 & 0.09 & 0.12 & 0.07 & 0.00 \\
\hline GrnBriar & 0.25 & 0.25 & 0.25 & 0.08 & 0.16 & 0.00 \\
\hline MtnGrape & 0.60 & 0.12 & 0.20 & 0.02 & 0.06 & 0.00 \\
\hline AnnIGrs & 0.06 & 0.32 & 0.20 & 0.22 & 0.20 & 0.00 \\
\hline OfThrAn & 0.09 & 0.33 & 0.10 & 0.15 & 0.33 & 0.00 \\
\hline KRBluStm & 0.24 & 0.36 & 0.15 & 0.15 & 0.10 & 0.00 \\
\hline SiBluStm & 0.22 & 0.33 & 0.16 & 0.17 & 0.12 & 0.00 \\
\hline SdOtsGrm & 0.19 & 0.30 & 0.14 & 0.13 & 0.14 & 0.00 \\
\hline HryGrm & 0.14 & 0.56 & 0.10 & 0.08 & 0.12 & 0.00 \\
\hline BrmdaGrs & 0.31 & 0.43 & 0.04 & 0.14 & 0.08 & 0.00 \\
\hline TxCupGrs & 0.06 & 0.32 & 0.20 & 0.22 & 0.20 & 0.00 \\
\hline SpMuhly & 0.10 & 0.46 & 0.15 & 0.10 & 0.19 & 0.00 \\
\hline LIBluStm & 0.22 & 0.33 & 0.10 & 0.16 & 0.19 & 0.00 \\
\hline IndnGrs & 0.25 & 0.37 & 0.13 & 0.13 & 0.12 & 0.00 \\
\hline IIDrpSd & 0.25 & 0.38 & 0.08 & 0.15 & 0.14 & 0.00 \\
\hline TxWntGrs & 0.12 & 0.44 & 0.14 & 0.12 & 0.18 & 0.00 \\
\hline CrlyMsqt & 0.14 & 0.56 & 0.08 & 0.06 & 0.16 & 0.00 \\
\hline BrmWd & 0.15 & 0.16 & 0.23 & 0.20 & 0.26 & 0.00 \\
\hline WdSedge & 0.13 & 0.50 & 0.15 & 0.06 & 0.16 & 0.00 \\
\hline RbtTbaco & 0.33 & 0.33 & 0.10 & 0.07 & 0.17 & 0.00 \\
\hline PrrBluet & 0.33 & 0.33 & 0.12 & 0.06 & 0.16 & 0.00 \\
\hline PrCnflwr & 0.33 & 0.33 & 0.13 & 0.04 & 0.17 & 0.00 \\
\hline TxSage & 0.30 & 0.30 & 0.13 & 0.07 & 0.20 & 0.00 \\
\hline DoveWeed & 0.20 & 0.05 & 0.19 & 0.09 & 0.47 & 0.00 \\
\hline & & & & \\
\hline
\end{tabular}

Note: Allocation is the proportion of initial biomass that is allocated to different plant components.

CRoot: Coarse Root

FRoot: Fine Root 
Table B2. Current allocation matrix.

\begin{tabular}{|c|c|c|c|c|c|c|c|}
\hline Species & Month & CRoot & FRoot & Trunk & Stems & Leaves & Seeds \\
\hline \multirow[t]{12}{*}{ NIHckbry } & Jan & 0.13 & 0.37 & 0.20 & 0.14 & 0.16 & 0.00 \\
\hline & Feb & 0.13 & 0.37 & 0.20 & 0.14 & 0.16 & 0.00 \\
\hline & Mar & 0.13 & 0.37 & 0.20 & 0.14 & 0.16 & 0.00 \\
\hline & Apr & 0.13 & 0.37 & 0.20 & 0.14 & 0.16 & 0.00 \\
\hline & \begin{tabular}{|l|} 
May \\
\end{tabular} & 0.13 & 0.37 & 0.20 & 0.14 & 0.16 & 0.00 \\
\hline & \begin{tabular}{|l|} 
Jun \\
\end{tabular} & 0.13 & 0.37 & 0.20 & 0.14 & 0.16 & 0.00 \\
\hline & Jul & 0.13 & 0.37 & 0.20 & 0.14 & 0.16 & 0.00 \\
\hline & Aug & 0.13 & 0.37 & 0.20 & 0.14 & 0.16 & 0.00 \\
\hline & Sep & 0.13 & 0.37 & 0.20 & 0.14 & 0.16 & 0.00 \\
\hline & Oct & 0.13 & 0.37 & 0.20 & 0.14 & 0.16 & 0.00 \\
\hline & Nov & 0.13 & 0.37 & 0.20 & 0.14 & 0.16 & 0.00 \\
\hline & Dec & 0.13 & 0.37 & 0.20 & 0.14 & 0.16 & 0.00 \\
\hline \multirow[t]{12}{*}{ TxPrsmmn } & Jan & 0.14 & 0.38 & 0.18 & 0.14 & 0.16 & 0.00 \\
\hline & Feb & 0.14 & 0.38 & 0.18 & 0.14 & 0.16 & 0.00 \\
\hline & Mar & 0.14 & 0.38 & 0.18 & 0.14 & 0.16 & 0.00 \\
\hline & Apr & 0.14 & 0.38 & 0.18 & 0.14 & 0.16 & 0.00 \\
\hline & May & 0.14 & 0.38 & 0.18 & 0.14 & 0.16 & 0.00 \\
\hline & Jun & 0.14 & 0.38 & 0.18 & 0.14 & 0.16 & 0.00 \\
\hline & Jul & 0.14 & 0.38 & 0.18 & 0.14 & 0.16 & 0.00 \\
\hline & Aug & 0.14 & 0.38 & 0.18 & 0.14 & 0.16 & 0.00 \\
\hline & Sep & 0.14 & 0.38 & 0.18 & 0.14 & 0.16 & 0.00 \\
\hline & Oct & 0.14 & 0.38 & 0.18 & 0.14 & 0.16 & 0.00 \\
\hline & Nov & 0.14 & 0.38 & 0.18 & 0.14 & 0.16 & 0.00 \\
\hline & Dec & 0.14 & 0.38 & 0.18 & 0.14 & 0.16 & 0.00 \\
\hline \multirow[t]{12}{*}{ AsheJunp } & Jan & 0.11 & 0.32 & 0.19 & 0.19 & 0.19 & 0.00 \\
\hline & Feb & 0.11 & 0.32 & 0.19 & 0.19 & 0.19 & 0.00 \\
\hline & Mar & 0.11 & 0.32 & 0.19 & 0.19 & 0.19 & 0.00 \\
\hline & Apr & 0.11 & 0.32 & 0.19 & 0.19 & 0.19 & 0.00 \\
\hline & May & 0.11 & 0.32 & 0.19 & 0.19 & 0.19 & 0.00 \\
\hline & Jun & 0.11 & 0.32 & 0.19 & 0.19 & 0.19 & 0.00 \\
\hline & Jul & 0.11 & 0.32 & 0.19 & 0.19 & 0.19 & 0.00 \\
\hline & Aug & 0.11 & 0.32 & 0.19 & 0.19 & 0.19 & 0.00 \\
\hline & Sep & 0.11 & 0.32 & 0.19 & 0.19 & 0.19 & 0.00 \\
\hline & Oct & 0.11 & 0.32 & 0.19 & 0.19 & 0.19 & 0.00 \\
\hline & Nov & 0.11 & 0.32 & 0.19 & 0.19 & 0.19 & 0.00 \\
\hline & Dec & 0.11 & 0.32 & 0.19 & 0.19 & 0.19 & 0.00 \\
\hline \multirow[t]{7}{*}{ ShRdOak } & Jan & 0.14 & 0.38 & 0.21 & 0.13 & 0.14 & 0.00 \\
\hline & Feb & 0.14 & 0.38 & 0.21 & 0.13 & 0.14 & 0.00 \\
\hline & Mar & 0.14 & 0.38 & 0.21 & 0.13 & 0.14 & 0.00 \\
\hline & Apr & 0.14 & 0.38 & 0.21 & 0.13 & 0.14 & 0.00 \\
\hline & May & 0.14 & 0.38 & 0.21 & 0.13 & 0.14 & 0.00 \\
\hline & Jun & 0.14 & 0.38 & 0.21 & 0.13 & 0.14 & 0.00 \\
\hline & Jul & 0.14 & 0.38 & 0.21 & 0.13 & 0.14 & 0.00 \\
\hline
\end{tabular}




\begin{tabular}{|c|c|c|c|c|c|c|c|}
\hline Species & Month & CRoot & FRoot & Trunk & Stems & Leaves & Seeds \\
\hline \multirow[t]{5}{*}{ ShRdOak (cont) } & Aug & 0.14 & 0.38 & 0.21 & 0.13 & 0.14 & 0.00 \\
\hline & Sep & 0.14 & 0.38 & 0.21 & 0.13 & 0.14 & 0.00 \\
\hline & Oct & 0.14 & 0.38 & 0.21 & 0.13 & 0.14 & 0.00 \\
\hline & Nov & 0.14 & 0.38 & 0.21 & 0.13 & 0.14 & 0.00 \\
\hline & Dec & 0.14 & 0.38 & 0.21 & 0.13 & 0.14 & 0.00 \\
\hline \multirow[t]{12}{*}{ LvOak } & Jan & 0.14 & 0.39 & 0.20 & 0.17 & 0.10 & 0.00 \\
\hline & Feb & 0.14 & 0.39 & 0.20 & 0.17 & 0.10 & 0.00 \\
\hline & Mar & 0.14 & 0.39 & 0.20 & 0.17 & 0.10 & 0.00 \\
\hline & Apr & 0.14 & 0.39 & 0.20 & 0.17 & 0.10 & 0.00 \\
\hline & May & 0.14 & 0.39 & 0.20 & 0.17 & 0.10 & 0.00 \\
\hline & Jun & 0.14 & 0.39 & 0.20 & 0.17 & 0.10 & 0.00 \\
\hline & Jul & 0.14 & 0.39 & 0.20 & 0.17 & 0.10 & 0.00 \\
\hline & \begin{tabular}{|l|} 
Aug \\
\end{tabular} & 0.14 & 0.39 & 0.20 & \begin{tabular}{|l|}
0.17 \\
\end{tabular} & 0.10 & 0.00 \\
\hline & Sep & 0.14 & 0.39 & 0.20 & 0.17 & 0.10 & 0.00 \\
\hline & Oct & 0.14 & 0.39 & 0.20 & 0.17 & 0.10 & 0.00 \\
\hline & Nov & 0.14 & 0.39 & 0.20 & 0.17 & 0.10 & 0.00 \\
\hline & Dec & 0.14 & 0.39 & 0.20 & 0.17 & 0.10 & 0.00 \\
\hline \multirow[t]{12}{*}{ CdrElm } & Jan & 0.13 & 0.38 & 0.21 & 0.13 & 0.15 & 0.00 \\
\hline & Feb & 0.13 & 0.38 & 0.21 & 0.13 & 0.15 & 0.00 \\
\hline & Mar & 0.13 & 0.38 & 0.21 & 0.13 & 0.15 & 0.00 \\
\hline & Apr & 0.13 & 0.38 & 0.21 & 0.13 & 0.15 & 0.00 \\
\hline & May & 0.13 & 0.38 & 0.21 & 0.13 & 0.15 & 0.00 \\
\hline & Jun & 0.13 & 0.38 & 0.21 & 0.13 & 0.15 & 0.00 \\
\hline & Jul & 0.13 & 0.38 & 0.21 & 0.13 & 0.15 & 0.00 \\
\hline & Aug & 0.13 & 0.38 & 0.21 & 0.13 & 0.15 & 0.00 \\
\hline & Sep & 0.13 & 0.38 & 0.21 & 0.13 & 0.15 & 0.00 \\
\hline & Oct & 0.13 & 0.38 & 0.21 & 0.13 & 0.15 & 0.00 \\
\hline & Nov & 0.13 & 0.38 & 0.21 & 0.13 & 0.15 & 0.00 \\
\hline & Dec & 0.13 & 0.38 & 0.21 & 0.13 & 0.15 & 0.00 \\
\hline \multirow[t]{12}{*}{ Mesquite } & Jan & 0.14 & 0.40 & 0.10 & 0.15 & 0.21 & 0.00 \\
\hline & Feb & 0.14 & 0.40 & 0.10 & 0.15 & 0.21 & 0.00 \\
\hline & Mar & 0.14 & 0.40 & 0.10 & 0.15 & 0.21 & 0.00 \\
\hline & Apr & 0.14 & 0.40 & 0.10 & 0.15 & 0.21 & 0.00 \\
\hline & May & 0.14 & 0.40 & 0.10 & 0.15 & 0.21 & 0.00 \\
\hline & \begin{tabular}{|l|} 
Jun \\
\end{tabular} & 0.14 & 0.40 & 0.10 & 0.15 & 0.21 & 0.00 \\
\hline & Jul & 0.14 & 0.40 & 0.10 & 0.15 & 0.21 & 0.00 \\
\hline & Aug & 0.14 & 0.40 & 0.10 & 0.15 & 0.21 & 0.00 \\
\hline & \begin{tabular}{|l|} 
Sep \\
\end{tabular} & 0.14 & 0.40 & 0.10 & 0.15 & 0.21 & 0.00 \\
\hline & Oct & 0.14 & 0.40 & 0.10 & 0.15 & 0.21 & 0.00 \\
\hline & Nov & 0.14 & 0.40 & 0.10 & 0.15 & 0.21 & 0.00 \\
\hline & Dec & 0.14 & 0.40 & 0.10 & 0.15 & 0.21 & 0.00 \\
\hline \multirow[t]{3}{*}{ Sotol } & Jan & 0.10 & 0.30 & 0.20 & 0.01 & 0.39 & 0.00 \\
\hline & Feb & 0.10 & 0.30 & 0.20 & 0.01 & 0.39 & 0.00 \\
\hline & Mar & 0.10 & 0.30 & 0.20 & 0.01 & 0.39 & 0.00 \\
\hline
\end{tabular}




\begin{tabular}{|c|c|c|c|c|c|c|c|}
\hline Species & Month & CRoot & FRoot & Trunk & Stems & Leaves & Seeds \\
\hline \multirow[t]{9}{*}{ Sotol (cont) } & Apr & 0.10 & 0.30 & 0.20 & 0.01 & 0.39 & 0.00 \\
\hline & May & 0.10 & 0.30 & 0.20 & 0.01 & 0.39 & 0.00 \\
\hline & Jun & 0.10 & 0.30 & 0.20 & 0.01 & 0.39 & 0.00 \\
\hline & Jul & 0.10 & 0.30 & 0.20 & 0.01 & 0.39 & 0.00 \\
\hline & Aug & 0.10 & 0.30 & 0.20 & 0.01 & 0.39 & 0.00 \\
\hline & Sep & 0.10 & 0.30 & 0.20 & 0.01 & 0.39 & 0.00 \\
\hline & Oct & 0.10 & 0.30 & 0.20 & 0.01 & 0.39 & 0.00 \\
\hline & Nov & 0.10 & 0.30 & 0.20 & 0.01 & 0.39 & 0.00 \\
\hline & Dec & 0.10 & 0.30 & 0.20 & 0.01 & 0.39 & 0.00 \\
\hline \multirow[t]{12}{*}{ EvgSumac } & Jan & 0.10 & 0.28 & 0.18 & 0.24 & 0.20 & 0.00 \\
\hline & Feb & 0.10 & 0.28 & 0.18 & 0.24 & 0.20 & 0.00 \\
\hline & Mar & 0.10 & 0.28 & 0.18 & 0.24 & 0.20 & 0.00 \\
\hline & Apr & 0.10 & 0.28 & 0.18 & 0.24 & 0.20 & 0.00 \\
\hline & May & 0.10 & 0.28 & 0.18 & 0.24 & 0.20 & 0.00 \\
\hline & Jun & 0.10 & 0.28 & 0.18 & 0.24 & 0.20 & 0.00 \\
\hline & Jul & 0.10 & 0.28 & 0.18 & 0.24 & 0.20 & 0.00 \\
\hline & Aug & 0.10 & 0.28 & 0.18 & 0.24 & 0.20 & 0.00 \\
\hline & Sep & 0.10 & 0.28 & 0.18 & 0.24 & 0.20 & 0.00 \\
\hline & Oct & 0.10 & 0.28 & 0.18 & 0.24 & 0.20 & 0.00 \\
\hline & Nov & 0.10 & 0.28 & 0.18 & 0.24 & 0.20 & 0.00 \\
\hline & Dec & 0.10 & 0.28 & 0.18 & 0.24 & 0.20 & 0.00 \\
\hline \multirow[t]{12}{*}{ GrnBriar } & Jan & 0.15 & 0.15 & 0.10 & 0.30 & 0.30 & 0.00 \\
\hline & Feb & 0.15 & 0.15 & 0.10 & 0.30 & 0.30 & 0.00 \\
\hline & Mar & 0.15 & 0.15 & 0.10 & 0.30 & 0.30 & 0.00 \\
\hline & Apr & 0.15 & 0.15 & 0.10 & 0.30 & 0.30 & 0.00 \\
\hline & May & 0.15 & 0.15 & 0.10 & 0.30 & 0.30 & 0.00 \\
\hline & Jun & 0.15 & 0.15 & 0.10 & 0.30 & 0.30 & 0.00 \\
\hline & Jul & 0.15 & 0.15 & 0.10 & 0.30 & 0.30 & 0.00 \\
\hline & Aug & 0.15 & 0.15 & 0.10 & 0.30 & 0.30 & 0.00 \\
\hline & Sep & 0.15 & 0.15 & 0.10 & 0.30 & 0.30 & 0.00 \\
\hline & Oct & 0.15 & 0.15 & 0.10 & 0.30 & 0.30 & 0.00 \\
\hline & Nov & 0.15 & 0.15 & 0.10 & 0.30 & 0.30 & 0.00 \\
\hline & Dec & 0.15 & 0.15 & 0.10 & 0.30 & 0.30 & 0.00 \\
\hline \multirow[t]{11}{*}{ MtnGrape } & Jan & 0.10 & 0.28 & 0.22 & 0.10 & 0.30 & 0.00 \\
\hline & Feb & 0.10 & 0.28 & 0.22 & 0.10 & 0.30 & 0.00 \\
\hline & Mar & 0.10 & 0.28 & 0.22 & 0.10 & 0.30 & 0.00 \\
\hline & Apr & 0.10 & 0.28 & 0.22 & 0.10 & 0.30 & 0.00 \\
\hline & May & 0.10 & 0.28 & 0.22 & \begin{tabular}{|l|}
0.10 \\
\end{tabular} & 0.30 & 0.00 \\
\hline & \begin{tabular}{|l|} 
Jun \\
\end{tabular} & 0.10 & 0.28 & 0.22 & 0.10 & 0.30 & 0.00 \\
\hline & Jul & 0.10 & 0.28 & 0.22 & \begin{tabular}{|l|}
0.10 \\
\end{tabular} & 0.30 & 0.00 \\
\hline & Aug & 0.10 & 0.28 & 0.22 & 0.10 & 0.30 & 0.00 \\
\hline & Sep & 0.10 & 0.28 & 0.22 & 0.10 & 0.30 & 0.00 \\
\hline & Oct & 0.10 & 0.28 & 0.22 & 0.10 & 0.30 & 0.00 \\
\hline & Nov & 0.10 & 0.28 & 0.22 & 0.10 & 0.30 & 0.00 \\
\hline
\end{tabular}




\begin{tabular}{|c|c|c|c|c|c|c|c|}
\hline Species & Month & CRoot & FRoot & Trunk & Stems & Leaves & Seeds \\
\hline MtnGrape (cont) & Dec & 0.10 & 0.28 & 0.22 & 0.10 & 0.30 & 0.00 \\
\hline \multirow[t]{12}{*}{ AnnlGrs } & Jan & 0.05 & 0.37 & 0.13 & 0.20 & 0.25 & 0.00 \\
\hline & Feb & 0.05 & 0.37 & 0.13 & 0.20 & 0.25 & 0.00 \\
\hline & Mar & 0.05 & 0.37 & 0.13 & 0.20 & 0.25 & 0.00 \\
\hline & Apr & 0.05 & 0.37 & 0.13 & 0.20 & 0.25 & 0.00 \\
\hline & May & 0.05 & 0.37 & 0.13 & 0.20 & 0.25 & 0.00 \\
\hline & Jun & 0.05 & 0.37 & 0.13 & 0.20 & 0.25 & 0.00 \\
\hline & \begin{tabular}{|l|}
$J u l$ \\
\end{tabular} & 0.05 & 0.37 & 0.13 & 0.20 & 0.25 & 0.00 \\
\hline & Aug & 0.05 & 0.37 & 0.13 & 0.20 & 0.25 & 0.00 \\
\hline & Sep & 0.05 & 0.37 & 0.13 & 0.20 & 0.25 & 0.00 \\
\hline & Oct & 0.05 & 0.37 & 0.13 & 0.20 & 0.25 & 0.00 \\
\hline & Nov & 0.05 & 0.37 & 0.13 & 0.20 & 0.25 & 0.00 \\
\hline & Dec & 0.05 & 0.37 & 0.13 & 0.20 & 0.25 & 0.00 \\
\hline \multirow[t]{12}{*}{ OfThrAn } & Jan & 0.08 & 0.34 & 0.10 & 0.15 & 0.33 & 0.00 \\
\hline & Feb & 0.08 & 0.34 & 0.10 & 0.15 & 0.33 & 0.00 \\
\hline & Mar & 0.08 & 0.34 & 0.10 & 0.15 & 0.33 & 0.00 \\
\hline & Apr & 0.08 & 0.34 & 0.10 & 0.15 & 0.33 & 0.00 \\
\hline & May & 0.08 & 0.34 & 0.10 & 0.15 & 0.33 & 0.00 \\
\hline & Jun & 0.08 & 0.34 & 0.10 & 0.15 & 0.33 & 0.00 \\
\hline & Jul & 0.08 & 0.34 & 0.10 & 0.15 & 0.33 & 0.00 \\
\hline & Aug & 0.08 & 0.34 & 0.10 & 0.15 & 0.33 & 0.00 \\
\hline & Sep & 0.08 & 0.34 & 0.10 & 0.15 & 0.33 & 0.00 \\
\hline & Oct & 0.08 & 0.34 & 0.10 & 0.15 & 0.33 & 0.00 \\
\hline & Nov & 0.08 & 0.34 & 0.10 & 0.15 & 0.33 & 0.00 \\
\hline & Dec & 0.08 & 0.34 & 0.10 & 0.15 & 0.33 & 0.00 \\
\hline \multirow[t]{12}{*}{ KRBluStm } & Jan & 0.08 & 0.35 & 0.14 & 0.17 & 0.28 & 0.00 \\
\hline & Feb & 0.08 & 0.35 & 0.14 & 0.17 & 0.28 & 0.00 \\
\hline & Mar & 0.08 & 0.35 & 0.14 & 0.17 & 0.28 & 0.00 \\
\hline & Apr & 0.08 & 0.35 & 0.14 & \begin{tabular}{|l|}
0.17 \\
\end{tabular} & 0.28 & 0.00 \\
\hline & May & 0.08 & 0.35 & 0.14 & \begin{tabular}{|l|}
0.17 \\
\end{tabular} & 0.28 & 0.00 \\
\hline & Jun & 0.08 & 0.35 & 0.14 & \begin{tabular}{|l|}
0.17 \\
\end{tabular} & 0.28 & 0.00 \\
\hline & \begin{tabular}{|l} 
Jul \\
\end{tabular} & 0.08 & 0.35 & 0.14 & 0.17 & 0.28 & 0.00 \\
\hline & Aug & 0.08 & 0.35 & 0.14 & 0.17 & 0.28 & 0.00 \\
\hline & Sep & 0.08 & 0.35 & 0.14 & 0.17 & 0.28 & 0.00 \\
\hline & Oct & 0.08 & 0.35 & 0.14 & \begin{tabular}{|l|}
0.17 \\
\end{tabular} & 0.28 & 0.00 \\
\hline & Nov & 0.08 & 0.35 & 0.14 & \begin{tabular}{|l|}
0.17 \\
\end{tabular} & 0.28 & 0.00 \\
\hline & Dec & 0.08 & 0.35 & 0.14 & 0.17 & 0.28 & 0.00 \\
\hline \multirow[t]{7}{*}{ SiBluStm } & Jan & 0.04 & 0.18 & 0.15 & 0.31 & 0.32 & 0.00 \\
\hline & Feb & 0.04 & 0.18 & 0.15 & 0.31 & 0.32 & 0.00 \\
\hline & Mar & 0.04 & 0.18 & 0.15 & 0.31 & 0.32 & 0.00 \\
\hline & Apr & 0.04 & 0.18 & 0.15 & 0.31 & 0.32 & 0.00 \\
\hline & May & 0.04 & 0.18 & 0.15 & 0.31 & 0.32 & 0.00 \\
\hline & Jun & 0.04 & 0.18 & 0.15 & 0.31 & 0.32 & 0.00 \\
\hline & Jul & 0.04 & 0.18 & 0.15 & 0.31 & 0.32 & 0.00 \\
\hline
\end{tabular}




\begin{tabular}{|c|c|c|c|c|c|c|c|}
\hline Species & Month & CRoot & FRoot & Trunk & Stems & Leaves & Seeds \\
\hline \multirow[t]{5}{*}{ SiBluStm (cont) } & Aug & 0.04 & 0.18 & 0.15 & 0.31 & 0.32 & 0.00 \\
\hline & Sep & 0.04 & 0.18 & 0.15 & 0.31 & 0.32 & 0.00 \\
\hline & Oct & 0.04 & 0.18 & 0.15 & 0.31 & 0.32 & 0.00 \\
\hline & Nov & 0.04 & 0.18 & 0.15 & 0.31 & 0.32 & 0.00 \\
\hline & Dec & 0.04 & 0.18 & 0.15 & 0.31 & 0.32 & 0.00 \\
\hline \multirow[t]{12}{*}{ SdOtsGrm } & Jan & 0.07 & 0.18 & 0.10 & 0.25 & 0.40 & 0.00 \\
\hline & Feb & 0.07 & 0.18 & 0.10 & 0.25 & 0.40 & 0.00 \\
\hline & Mar & 0.07 & 0.18 & 0.10 & 0.25 & 0.40 & 0.00 \\
\hline & Apr & 0.07 & 0.18 & 0.10 & 0.25 & 0.40 & 0.00 \\
\hline & May & 0.07 & 0.18 & 0.10 & 0.25 & 0.40 & 0.00 \\
\hline & Jun & 0.07 & 0.18 & 0.10 & 0.25 & 0.40 & 0.00 \\
\hline & Jul & 0.07 & 0.18 & 0.10 & 0.25 & 0.40 & 0.00 \\
\hline & Aug & 0.07 & \begin{tabular}{|l|l|}
0.18 \\
\end{tabular} & 0.10 & 0.25 & 0.40 & 0.00 \\
\hline & Sep & 0.07 & 0.18 & 0.10 & 0.25 & 0.40 & 0.00 \\
\hline & Oct & 0.07 & 0.18 & 0.10 & 0.25 & 0.40 & 0.00 \\
\hline & Nov & 0.07 & 0.18 & 0.10 & 0.25 & 0.40 & 0.00 \\
\hline & Dec & 0.07 & 0.18 & 0.10 & 0.25 & 0.40 & 0.00 \\
\hline \multirow[t]{12}{*}{ HryGrm } & Jan & 0.02 & 0.17 & 0.10 & 0.08 & 0.63 & 0.00 \\
\hline & Feb & 0.02 & 0.17 & 0.10 & 0.08 & 0.63 & 0.00 \\
\hline & Mar & 0.02 & 0.17 & 0.10 & 0.08 & 0.63 & 0.00 \\
\hline & Apr & 0.02 & 0.17 & 0.10 & 0.08 & 0.63 & 0.00 \\
\hline & May & 0.02 & 0.17 & 0.10 & 0.08 & 0.63 & 0.00 \\
\hline & Jun & 0.02 & 0.17 & 0.10 & 0.08 & 0.63 & 0.00 \\
\hline & Jul & 0.02 & 0.17 & 0.10 & 0.08 & 0.63 & 0.00 \\
\hline & Aug & 0.02 & 0.17 & 0.10 & 0.08 & 0.63 & 0.00 \\
\hline & Sep & 0.02 & 0.17 & 0.10 & 0.08 & 0.63 & 0.00 \\
\hline & Oct & 0.02 & 0.17 & 0.10 & 0.08 & 0.63 & 0.00 \\
\hline & Nov & 0.02 & 0.17 & 0.10 & 0.08 & 0.63 & 0.00 \\
\hline & Dec & 0.02 & 0.17 & 0.10 & 0.08 & 0.63 & 0.00 \\
\hline \multirow[t]{12}{*}{ BrmdaGrs } & Jan & 0.06 & 0.24 & 0.11 & 0.39 & 0.20 & 0.00 \\
\hline & Feb & 0.06 & 0.24 & 0.11 & 0.39 & 0.20 & 0.00 \\
\hline & Mar & 0.06 & 0.24 & 0.11 & 0.39 & 0.20 & 0.00 \\
\hline & Apr & 0.06 & 0.24 & 0.11 & 0.39 & 0.20 & 0.00 \\
\hline & May & 0.06 & 0.24 & 0.11 & 0.39 & 0.20 & 0.00 \\
\hline & \begin{tabular}{|l|} 
Jun \\
\end{tabular} & 0.06 & 0.24 & 0.11 & 0.39 & 0.20 & 0.00 \\
\hline & Jul & 0.06 & 0.24 & 0.11 & 0.39 & 0.20 & 0.00 \\
\hline & Aug & 0.06 & 0.24 & 0.11 & 0.39 & 0.20 & 0.00 \\
\hline & Sep & 0.06 & 0.24 & 0.11 & 0.39 & 0.20 & 0.00 \\
\hline & Oct & 0.06 & 0.24 & 0.11 & 0.39 & 0.20 & 0.00 \\
\hline & Nov & 0.06 & 0.24 & 0.11 & 0.39 & 0.20 & 0.00 \\
\hline & Dec & 0.06 & 0.24 & 0.11 & 0.39 & 0.20 & 0.00 \\
\hline \multirow[t]{2}{*}{ TxCupGrs } & Jan & 0.05 & 0.37 & 0.13 & 0.20 & 0.25 & 0.00 \\
\hline & Feb & 0.05 & 0.37 & 0.13 & 0.20 & 0.25 & 0.00 \\
\hline
\end{tabular}




\begin{tabular}{|c|c|c|c|c|c|c|c|}
\hline Species & Month & CRoot & FRoot & Trunk & Stems & Leaves & Seeds \\
\hline \multirow[t]{10}{*}{ TxCupGrs (cont) } & Mar & 0.05 & 0.37 & 0.13 & 0.20 & 0.25 & 0.00 \\
\hline & Apr & 0.05 & 0.37 & 0.13 & 0.20 & 0.25 & 0.00 \\
\hline & May & 0.05 & 0.37 & 0.13 & 0.20 & 0.25 & 0.00 \\
\hline & Jun & 0.05 & 0.37 & 0.13 & 0.20 & 0.25 & 0.00 \\
\hline & Jul & 0.05 & 0.37 & 0.13 & 0.20 & 0.25 & 0.00 \\
\hline & Aug & 0.05 & 0.37 & 0.13 & 0.20 & 0.25 & 0.00 \\
\hline & Sep & 0.05 & 0.37 & 0.13 & 0.20 & 0.25 & 0.00 \\
\hline & Oct & 0.05 & 0.37 & 0.13 & 0.20 & 0.25 & 0.00 \\
\hline & Nov & 0.05 & 0.37 & 0.13 & 0.20 & 0.25 & 0.00 \\
\hline & Dec & 0.05 & 0.37 & 0.13 & 0.20 & 0.25 & 0.00 \\
\hline \multirow[t]{12}{*}{ SpMuhly } & Jan & 0.02 & 0.09 & 0.20 & 0.20 & 0.49 & 0.00 \\
\hline & Feb & 0.02 & 0.09 & 0.20 & 0.20 & 0.49 & 0.00 \\
\hline & Mar & 0.02 & 0.09 & 0.20 & 0.20 & 0.49 & 0.00 \\
\hline & Apr & 0.02 & 0.09 & 0.20 & 0.20 & 0.49 & 0.00 \\
\hline & May & 0.02 & 0.09 & 0.20 & 0.20 & 0.49 & 0.00 \\
\hline & Jun & 0.02 & 0.09 & 0.20 & 0.20 & 0.49 & 0.00 \\
\hline & Jul & 0.02 & 0.09 & 0.20 & 0.20 & 0.49 & 0.00 \\
\hline & Aug & 0.02 & 0.09 & 0.20 & 0.20 & 0.49 & 0.00 \\
\hline & Sep & 0.02 & 0.09 & 0.20 & 0.20 & 0.49 & 0.00 \\
\hline & Oct & 0.02 & 0.09 & 0.20 & 0.20 & 0.49 & 0.00 \\
\hline & Nov & 0.02 & 0.09 & 0.20 & 0.20 & 0.49 & 0.00 \\
\hline & Dec & 0.02 & 0.09 & 0.20 & 0.20 & 0.49 & 0.00 \\
\hline \multirow[t]{12}{*}{ LIBluStm } & Jan & 0.04 & 0.16 & 0.20 & 0.30 & 0.30 & 0.00 \\
\hline & Feb & 0.04 & 0.16 & 0.20 & 0.30 & 0.30 & 0.00 \\
\hline & Mar & 0.04 & 0.16 & 0.20 & 0.30 & 0.30 & 0.00 \\
\hline & Apr & 0.04 & 0.16 & 0.20 & 0.30 & 0.30 & 0.00 \\
\hline & May & 0.04 & 0.16 & 0.20 & 0.30 & 0.30 & 0.00 \\
\hline & Jun & 0.04 & 0.16 & 0.20 & 0.30 & 0.30 & 0.00 \\
\hline & Jul & 0.04 & 0.16 & 0.20 & 0.30 & 0.30 & 0.00 \\
\hline & Aug & 0.04 & 0.16 & 0.20 & 0.30 & 0.30 & 0.00 \\
\hline & Sep & 0.04 & 0.16 & 0.20 & 0.30 & 0.30 & 0.00 \\
\hline & Oct & 0.04 & 0.16 & 0.20 & 0.30 & 0.30 & 0.00 \\
\hline & Nov & 0.04 & 0.16 & 0.20 & 0.30 & 0.30 & 0.00 \\
\hline & Dec & 0.04 & 0.16 & 0.20 & 0.30 & 0.30 & 0.00 \\
\hline \multirow[t]{9}{*}{ IndnGrs } & Jan & 0.08 & 0.35 & 0.15 & 0.22 & 0.20 & 0.00 \\
\hline & Feb & 0.08 & 0.35 & 0.15 & 0.22 & 0.20 & 0.00 \\
\hline & Mar & 0.08 & 0.35 & 0.15 & 0.22 & 0.20 & 0.00 \\
\hline & Apr & 0.08 & 0.35 & 0.15 & 0.22 & 0.20 & 0.00 \\
\hline & May & 0.08 & 0.35 & 0.15 & 0.22 & 0.20 & 0.00 \\
\hline & Jun & 0.08 & 0.35 & 0.15 & 0.22 & 0.20 & 0.00 \\
\hline & Jul & 0.08 & 0.35 & 0.15 & 0.22 & 0.20 & 0.00 \\
\hline & Aug & 0.08 & 0.35 & 0.15 & 0.22 & 0.20 & 0.00 \\
\hline & Sep & 0.08 & 0.35 & 0.15 & 0.22 & 0.20 & 0.00 \\
\hline
\end{tabular}




\begin{tabular}{|c|c|c|c|c|c|c|c|}
\hline Species & Month & CRoot & FRoot & Trunk & Stems & Leaves & Seeds \\
\hline \multirow[t]{3}{*}{ IndnGrs (cont) } & Oct & 0.08 & 0.35 & 0.15 & 0.22 & 0.20 & 0.00 \\
\hline & Nov & 0.08 & 0.35 & 0.15 & 0.22 & 0.20 & 0.00 \\
\hline & Dec & 0.08 & 0.35 & 0.15 & 0.22 & 0.20 & 0.00 \\
\hline \multirow[t]{12}{*}{ TIDrpSd } & Jan & 0.08 & 0.30 & 0.14 & 0.22 & 0.26 & 0.00 \\
\hline & Feb & 0.08 & 0.30 & 0.14 & 0.22 & 0.26 & 0.00 \\
\hline & Mar & 0.08 & 0.30 & 0.14 & 0.22 & 0.26 & 0.00 \\
\hline & Apr & 0.08 & 0.30 & 0.14 & 0.22 & 0.26 & 0.00 \\
\hline & May & 0.08 & 0.30 & 0.14 & 0.22 & 0.26 & 0.00 \\
\hline & Jun & 0.08 & 0.30 & 0.14 & 0.22 & 0.26 & 0.00 \\
\hline & Jul & 0.08 & 0.30 & 0.14 & 0.22 & 0.26 & 0.00 \\
\hline & Aug & 0.08 & 0.30 & 0.14 & 0.22 & 0.26 & 0.00 \\
\hline & Sep & 0.08 & 0.30 & 0.14 & 0.22 & 0.26 & 0.00 \\
\hline & Oct & 0.08 & 0.30 & 0.14 & 0.22 & 0.26 & 0.00 \\
\hline & Nov & 0.08 & 0.30 & 0.14 & 0.22 & 0.26 & 0.00 \\
\hline & Dec & 0.08 & 0.30 & 0.14 & 0.22 & 0.26 & 0.00 \\
\hline \multirow{12}{*}{ TxWntGrs } & Jan & 0.04 & 0.38 & 0.14 & 0.14 & 0.30 & 0.00 \\
\hline & Feb & 0.04 & 0.38 & 0.14 & 0.14 & 0.30 & 0.00 \\
\hline & Mar & 0.04 & 0.38 & 0.14 & 0.14 & 0.30 & 0.00 \\
\hline & Apr & 0.04 & 0.38 & 0.14 & 0.14 & 0.30 & 0.00 \\
\hline & May & 0.04 & 0.38 & 0.14 & 0.14 & 0.30 & 0.00 \\
\hline & Jun & 0.04 & 0.38 & 0.14 & 0.14 & 0.30 & 0.00 \\
\hline & Jul & 0.04 & 0.38 & 0.14 & 0.14 & 0.30 & 0.00 \\
\hline & Aug & 0.04 & 0.38 & 0.14 & 0.14 & 0.30 & 0.00 \\
\hline & Sep & 0.04 & 0.38 & 0.14 & 0.14 & 0.30 & 0.00 \\
\hline & Oct & 0.04 & 0.38 & 0.14 & 0.14 & 0.30 & 0.00 \\
\hline & Nov & 0.04 & 0.38 & 0.14 & 0.14 & 0.30 & 0.00 \\
\hline & Dec & 0.04 & 0.38 & 0.14 & 0.14 & 0.30 & 0.00 \\
\hline \multirow[t]{12}{*}{ CrlyMsqt } & Jan & 0.03 & 0.18 & 0.08 & 0.21 & 0.50 & 0.00 \\
\hline & Feb & 0.03 & 0.18 & 0.08 & 0.21 & 0.50 & 0.00 \\
\hline & Mar & 0.03 & 0.18 & 0.08 & 0.21 & 0.50 & 0.00 \\
\hline & Apr & 0.03 & 0.18 & 0.08 & 0.21 & 0.50 & 0.00 \\
\hline & May & 0.03 & 0.18 & 0.08 & 0.21 & 0.50 & 0.00 \\
\hline & \begin{tabular}{|l|} 
Jun \\
\end{tabular} & 0.03 & 0.18 & 0.08 & 0.21 & 0.50 & 0.00 \\
\hline & Jul & 0.03 & 0.18 & 0.08 & 0.21 & 0.50 & 0.00 \\
\hline & Aug & 0.03 & 0.18 & 0.08 & 0.21 & 0.50 & 0.00 \\
\hline & Sep & 0.03 & 0.18 & 0.08 & 0.21 & 0.50 & 0.00 \\
\hline & Oct & 0.03 & 0.18 & 0.08 & 0.21 & 0.50 & 0.00 \\
\hline & Nov & 0.03 & 0.18 & 0.08 & 0.21 & 0.50 & 0.00 \\
\hline & Dec & 0.03 & 0.18 & 0.08 & 0.21 & 0.50 & 0.00 \\
\hline \multirow[t]{4}{*}{ BrmWd } & Jan & 0.15 & 0.16 & 0.23 & 0.20 & 0.26 & 0.00 \\
\hline & Feb & 0.15 & 0.16 & 0.23 & 0.20 & 0.26 & 0.00 \\
\hline & Mar & 0.15 & 0.16 & 0.23 & 0.20 & 0.26 & 0.00 \\
\hline & Apr & 0.15 & 0.16 & 0.23 & 0.20 & 0.26 & 0.00 \\
\hline
\end{tabular}




\begin{tabular}{|c|c|c|c|c|c|c|c|}
\hline Species & Month & CRoot & FRoot & Trunk & Stems & Leaves & Seeds \\
\hline \multirow[t]{8}{*}{ BrmWd (cont) } & May & 0.15 & 0.16 & 0.23 & 0.20 & 0.26 & 0.00 \\
\hline & Jun & 0.15 & 0.16 & 0.23 & 0.20 & 0.26 & 0.00 \\
\hline & Jul & 0.15 & 0.16 & 0.23 & 0.20 & 0.26 & 0.00 \\
\hline & Aug & 0.15 & 0.16 & 0.23 & 0.20 & 0.26 & 0.00 \\
\hline & Sep & 0.15 & 0.16 & 0.23 & 0.20 & 0.26 & 0.00 \\
\hline & Oct & 0.15 & 0.16 & 0.23 & 0.20 & 0.26 & 0.00 \\
\hline & Nov & 0.15 & 0.16 & 0.23 & 0.20 & 0.26 & 0.00 \\
\hline & Dec & 0.15 & 0.16 & 0.23 & 0.20 & 0.26 & 0.00 \\
\hline \multirow[t]{12}{*}{ WdSedge } & Jan & 0.03 & 0.20 & 0.33 & 0.04 & 0.40 & 0.00 \\
\hline & Feb & 0.03 & 0.20 & 0.33 & 0.04 & 0.40 & 0.00 \\
\hline & Mar & 0.03 & 0.20 & 0.33 & 0.04 & 0.40 & 0.00 \\
\hline & Apr & 0.03 & 0.20 & 0.33 & 0.04 & 0.40 & 0.00 \\
\hline & May & 0.03 & 0.20 & 0.33 & 0.04 & 0.40 & 0.00 \\
\hline & Jun & 0.03 & 0.20 & 0.33 & 0.04 & 0.40 & 0.00 \\
\hline & Jul & 0.03 & 0.20 & 0.33 & 0.04 & 0.40 & 0.00 \\
\hline & Aug & 0.03 & 0.20 & 0.33 & 0.04 & 0.40 & 0.00 \\
\hline & Sep & 0.03 & 0.20 & 0.33 & 0.04 & 0.40 & 0.00 \\
\hline & Oct & 0.03 & 0.20 & 0.33 & 0.04 & 0.40 & 0.00 \\
\hline & Nov & 0.03 & 0.20 & 0.33 & 0.04 & 0.40 & 0.00 \\
\hline & Dec & 0.03 & 0.20 & 0.33 & 0.04 & 0.40 & 0.00 \\
\hline \multirow[t]{12}{*}{ RbtTbaco } & Jan & 0.26 & 0.40 & 0.08 & 0.04 & 0.22 & 0.00 \\
\hline & Feb & 0.26 & 0.40 & 0.08 & 0.04 & 0.22 & 0.00 \\
\hline & Mar & 0.26 & 0.40 & 0.08 & 0.04 & 0.22 & 0.00 \\
\hline & Apr & 0.26 & 0.40 & 0.08 & 0.04 & 0.22 & 0.00 \\
\hline & May & 0.26 & 0.40 & 0.08 & 0.04 & 0.22 & 0.00 \\
\hline & Jun & 0.26 & 0.40 & 0.08 & 0.04 & 0.22 & 0.00 \\
\hline & Jul & 0.26 & 0.40 & 0.08 & 0.04 & 0.22 & 0.00 \\
\hline & Aug & 0.26 & 0.40 & 0.08 & 0.04 & 0.22 & 0.00 \\
\hline & Sep & 0.26 & 0.40 & 0.08 & 0.04 & 0.22 & 0.00 \\
\hline & Oct & 0.26 & 0.40 & 0.08 & 0.04 & 0.22 & 0.00 \\
\hline & Nov & 0.26 & 0.40 & 0.08 & 0.04 & 0.22 & 0.00 \\
\hline & Dec & 0.26 & 0.40 & 0.08 & 0.04 & 0.22 & 0.00 \\
\hline \multirow[t]{12}{*}{ PrrBluet } & Jan & 0.14 & 0.15 & 0.15 & 0.20 & 0.36 & 0.00 \\
\hline & Feb & 0.14 & 0.15 & 0.15 & 0.20 & 0.36 & 0.00 \\
\hline & Mar & 0.14 & 0.15 & 0.15 & 0.20 & 0.36 & 0.00 \\
\hline & Apr & 0.14 & 0.15 & 0.15 & 0.20 & 0.36 & 0.00 \\
\hline & May & 0.14 & 0.15 & 0.15 & 0.20 & 0.36 & 0.00 \\
\hline & \begin{tabular}{|l|} 
Jun \\
\end{tabular} & 0.14 & 0.15 & 0.15 & 0.20 & 0.36 & 0.00 \\
\hline & Jul & 0.14 & 0.15 & 0.15 & 0.20 & 0.36 & 0.00 \\
\hline & Aug & 0.14 & 0.15 & 0.15 & 0.20 & 0.36 & 0.00 \\
\hline & Sep & 0.14 & 0.15 & 0.15 & 0.20 & 0.36 & 0.00 \\
\hline & Oct & 0.14 & 0.15 & 0.15 & 0.20 & 0.36 & 0.00 \\
\hline & Nov & 0.14 & 0.15 & 0.15 & 0.20 & 0.36 & 0.00 \\
\hline & Dec & 0.14 & 0.15 & 0.15 & 0.20 & 0.36 & 0.00 \\
\hline
\end{tabular}




\begin{tabular}{|c|c|c|c|c|c|c|c|}
\hline Species & Month & CRoot & FRoot & Trunk & Stems & Leaves & Seeds \\
\hline \multirow[t]{12}{*}{ PrCnflwr } & Jan & 0.15 & 0.15 & 0.24 & 0.10 & 0.36 & 0.00 \\
\hline & Feb & 0.15 & 0.15 & 0.24 & 0.10 & 0.36 & 0.00 \\
\hline & Mar & 0.15 & 0.15 & 0.24 & 0.10 & 0.36 & 0.00 \\
\hline & Apr & 0.15 & 0.15 & 0.24 & 0.10 & 0.36 & 0.00 \\
\hline & May & 0.15 & 0.15 & 0.24 & 0.10 & 0.36 & 0.00 \\
\hline & Jun & 0.15 & 0.15 & 0.24 & 0.10 & 0.36 & 0.00 \\
\hline & Jul & 0.15 & 0.15 & 0.24 & 0.10 & 0.36 & 0.00 \\
\hline & Aug & 0.15 & 0.15 & 0.24 & 0.10 & 0.36 & 0.00 \\
\hline & Sep & 0.15 & 0.15 & 0.24 & 0.10 & 0.36 & 0.00 \\
\hline & Oct & 0.15 & 0.15 & 0.24 & 0.10 & 0.36 & 0.00 \\
\hline & Nov & 0.15 & 0.15 & 0.24 & 0.10 & 0.36 & 0.00 \\
\hline & Dec & 0.15 & 0.15 & 0.24 & 0.10 & 0.36 & 0.00 \\
\hline \multirow[t]{12}{*}{ TxSage } & \begin{tabular}{|l|}
$J a n$ \\
\end{tabular} & 0.24 & 0.36 & 0.10 & 0.05 & 0.25 & 0.00 \\
\hline & Feb & 0.24 & 0.36 & 0.10 & 0.05 & 0.25 & 0.00 \\
\hline & Mar & 0.24 & 0.36 & 0.10 & 0.05 & 0.25 & 0.00 \\
\hline & Apr & 0.24 & 0.36 & 0.10 & 0.05 & 0.25 & 0.00 \\
\hline & May & 0.24 & 0.36 & 0.10 & 0.05 & 0.25 & 0.00 \\
\hline & Jun & 0.24 & 0.36 & 0.10 & 0.05 & 0.25 & 0.00 \\
\hline & Jul & 0.24 & 0.36 & 0.10 & 0.05 & 0.25 & 0.00 \\
\hline & Aug & 0.24 & 0.36 & 0.10 & 0.05 & 0.25 & 0.00 \\
\hline & Sep & 0.24 & 0.36 & 0.10 & 0.05 & 0.25 & 0.00 \\
\hline & Oct & 0.24 & 0.36 & 0.10 & 0.05 & 0.25 & 0.00 \\
\hline & Nov & 0.24 & 0.36 & 0.10 & 0.05 & 0.25 & 0.00 \\
\hline & Dec & 0.24 & 0.36 & 0.10 & 0.05 & 0.25 & 0.00 \\
\hline \multirow[t]{12}{*}{ DoveWeed } & Jan & 0.05 & 0.15 & 0.20 & 0.10 & 0.50 & 0.00 \\
\hline & Feb & 0.05 & 0.15 & 0.20 & 0.10 & 0.50 & 0.00 \\
\hline & Mar & 0.05 & 0.15 & 0.20 & 0.10 & 0.50 & 0.00 \\
\hline & Apr & 0.05 & 0.15 & 0.20 & 0.10 & 0.50 & 0.00 \\
\hline & May & 0.05 & 0.15 & 0.20 & 0.10 & 0.50 & 0.00 \\
\hline & Jun & 0.05 & 0.15 & 0.20 & 0.10 & 0.50 & 0.00 \\
\hline & Jul & 0.05 & 0.15 & 0.20 & 0.10 & 0.50 & 0.00 \\
\hline & Aug & 0.05 & 0.15 & 0.20 & 0.10 & 0.50 & 0.00 \\
\hline & Sep & 0.05 & 0.15 & 0.20 & 0.10 & 0.50 & 0.00 \\
\hline & Oct & 0.05 & 0.15 & 0.20 & 0.10 & 0.50 & 0.00 \\
\hline & Nov & 0.05 & 0.15 & 0.20 & 0.10 & 0.50 & 0.00 \\
\hline & Dec & 0.05 & 0.15 & 0.20 & 0.10 & 0.50 & 0.00 \\
\hline
\end{tabular}

Note: Allocation is the proportion of new growth biomass that is allocated to different plant components. 
Table B3. SeedMonthAllocation matrix.

\begin{tabular}{|c|c|c|c|c|c|c|}
\hline Species & CRoot & FRoot & Trunk & Stems & Leaves & Seeds \\
\hline NIHckbry & 0.13 & 0.37 & 0.10 & 0.07 & 0.14 & 0.19 \\
\hline TxPrsmmn & 0.14 & 0.38 & 0.09 & 0.07 & 0.14 & 0.18 \\
\hline AsheJunp & 0.11 & 0.32 & 0.10 & 0.10 & 0.27 & 0.10 \\
\hline ShRdOak & 0.14 & 0.38 & 0.10 & 0.07 & 0.13 & 0.18 \\
\hline LvOak & 0.14 & 0.39 & 0.15 & 0.16 & 0.10 & 0.06 \\
\hline CdrElm & 0.13 & 0.38 & 0.10 & 0.07 & 0.13 & 0.19 \\
\hline Mesquite & 0.10 & 0.30 & 0.02 & 0.07 & 0.19 & 0.32 \\
\hline Sotol & 0.10 & 0.30 & 0.00 & 0.00 & 0.35 & 0.25 \\
\hline EvgSumac & 0.10 & 0.28 & 0.09 & 0.12 & 0.18 & 0.23 \\
\hline GrnBriar & 0.00 & 0.15 & 0.00 & 0.30 & 0.27 & 0.28 \\
\hline MtnGrape & 0.10 & 0.28 & 0.11 & 0.05 & 0.27 & 0.19 \\
\hline AnnlGrs & 0.00 & 0.37 & 0.00 & 0.20 & 0.12 & 0.40 \\
\hline OfThrAn & 0.00 & 0.00 & 0.00 & 0.20 & 0.00 & 0.80 \\
\hline KRBluStm & 0.00 & 0.35 & 0.00 & 0.19 & 0.19 & 0.27 \\
\hline SiBluStm & 0.00 & 0.18 & 0.00 & 0.16 & 0.29 & 0.37 \\
\hline SdOtsGrm & 0.00 & 0.48 & 0.00 & 0.05 & 0.20 & 0.27 \\
\hline HryGrm & 0.00 & 0.17 & 0.00 & 0.08 & 0.57 & 0.18 \\
\hline BrmdaGrs & 0.00 & 0.24 & 0.00 & 0.39 & 0.10 & 0.27 \\
\hline TxCupGrs & 0.00 & 0.37 & 0.00 & 0.20 & 0.12 & 0.40 \\
\hline SpMuhly & 0.00 & 0.09 & 0.00 & 0.20 & 0.24 & 0.47 \\
\hline LIBluStm & 0.00 & 0.16 & 0.00 & 0.27 & 0.27 & 0.30 \\
\hline IndnGrs & 0.00 & 0.35 & 0.00 & 0.22 & 0.10 & 0.33 \\
\hline TIDrpSd & 0.00 & 0.30 & 0.00 & 0.19 & 0.23 & 0.28 \\
\hline TxWntGrs & 0.00 & 0.38 & 0.00 & 0.07 & 0.27 & 0.28 \\
\hline CrlyMsqt & 0.00 & 0.18 & 0.00 & 0.28 & 0.28 & 0.26 \\
\hline BrmWd & 0.00 & 0.00 & 0.00 & 0.10 & 0.03 & 0.83 \\
\hline WdSedge & 0.00 & 0.20 & 0.00 & 0.04 & 0.20 & 0.56 \\
\hline RbtTbaco & 0.00 & 0.40 & 0.00 & 0.04 & 0.11 & 0.45 \\
\hline PrrBluet & 0.00 & 0.15 & 0.00 & 0.10 & 0.32 & 0.43 \\
\hline PrCnflwr & 0.00 & 0.15 & 0.00 & 0.05 & 0.18 & 0.62 \\
\hline TxSage & 0.00 & 0.36 & 0.00 & 0.05 & 0.12 & 0.47 \\
\hline DoveWeed & 0.00 & 0.00 & 0.00 & 0.00 & 0.15 & 0.85 \\
\hline
\end{tabular}

Note: SeedMonthAllocation is the new growth allocation during seed producing months. 
Table B4. GreenOutAllocation matrix.

\begin{tabular}{|c|c|c|c|c|c|c|}
\hline Species & CRoot & FRoot & Trunk & Stems & Leaves & Seeds \\
\hline NIHckbry & 0.00 & 0.35 & 0.15 & 0.15 & 0.35 & 0.00 \\
\hline TxPrsmmn & 0.00 & 0.35 & 0.15 & 0.15 & 0.35 & 0.00 \\
\hline AsheJunp & 0.00 & 0.30 & 0.15 & 0.20 & 0.35 & 0.00 \\
\hline ShRdOak & 0.00 & 0.35 & 0.20 & 0.15 & 0.30 & 0.00 \\
\hline LvOak & 0.00 & 0.35 & 0.15 & 0.15 & 0.35 & 0.00 \\
\hline CdrElm & 0.00 & 0.35 & 0.15 & 0.15 & 0.35 & 0.00 \\
\hline Mesquite & 0.00 & 0.40 & 0.10 & 0.13 & 0.37 & 0.00 \\
\hline Sotol & 0.00 & 0.30 & 0.00 & 0.05 & 0.65 & 0.00 \\
\hline EvgSumac & 0.00 & 0.25 & 0.15 & 0.30 & 0.30 & 0.00 \\
\hline GrnBriar & 0.00 & 0.10 & 0.00 & 0.20 & 0.70 & 0.00 \\
\hline MtnGrape & 0.00 & 0.25 & 0.20 & 0.15 & 0.40 & 0.00 \\
\hline AnnlGrs & 0.00 & 0.35 & 0.00 & 0.25 & 0.40 & 0.00 \\
\hline OfThrAn & 0.00 & 0.30 & 0.00 & 0.10 & 0.60 & 0.00 \\
\hline KRBluStm & 0.00 & 0.30 & 0.00 & 0.20 & 0.50 & 0.00 \\
\hline SiBluStm & 0.00 & 0.15 & 0.00 & 0.40 & 0.45 & 0.00 \\
\hline SdOtsGrm & 0.00 & 0.45 & 0.00 & 0.10 & 0.45 & 0.00 \\
\hline HryGrm & 0.00 & 0.15 & 0.00 & 0.00 & 0.85 & 0.00 \\
\hline BrmdaGrs & 0.00 & 0.20 & 0.00 & 0.49 & 0.31 & 0.00 \\
\hline TxCupGrs & 0.00 & 0.35 & 0.00 & 0.25 & 0.40 & 0.00 \\
\hline SpMuhly & 0.00 & 0.10 & 0.00 & 0.20 & 0.70 & 0.00 \\
\hline LIBluStm & 0.00 & 0.15 & 0.00 & 0.40 & 0.45 & 0.00 \\
\hline IndnGrs & 0.00 & 0.35 & 0.00 & 0.25 & 0.40 & 0.00 \\
\hline TIDrpSd & 0.00 & 0.25 & 0.00 & 0.30 & 0.45 & 0.00 \\
\hline TxWntGrs & 0.00 & 0.30 & 0.00 & 0.15 & 0.55 & 0.00 \\
\hline CrlyMsqt & 0.00 & 0.15 & 0.00 & 0.10 & 0.75 & 0.00 \\
\hline BrmWd & 0.00 & 0.10 & 0.25 & 0.20 & 0.45 & 0.00 \\
\hline WdSedge & 0.00 & 0.20 & 0.00 & 0.04 & 0.76 & 0.00 \\
\hline RbtTbaco & 0.00 & 0.40 & 0.00 & 0.05 & 0.55 & 0.00 \\
\hline PrrBluet & 0.00 & 0.10 & 0.00 & 0.10 & 0.80 & 0.00 \\
\hline PrCnflwr & 0.00 & 0.10 & 0.15 & 0.05 & 0.70 & 0.00 \\
\hline TxSage & 0.00 & 0.35 & 0.00 & 0.10 & 0.55 & 0.00 \\
\hline DoveWeed & 0.00 & 0.05 & 0.00 & 0.35 & 0.60 & 0.00 \\
\hline
\end{tabular}

Note: GreenOutAllocation is the new growth allocation during spring green-out months. 
Table B5. PlantNConc matrix.

\begin{tabular}{|c|c|c|c|c|c|c|c|c|c|c|c|}
\hline ec & Root & Root & unk & ems & Leaves & Seeds & SDStems & SDLeaves & SdlgRoot & SdlgShoot & s \\
\hline NIHckbry & 060 & 125 & 030 & 063 & 140 & 060 & & 0 & 30 & 0 & \\
\hline $\mathrm{nn}$ & 0062 & 0.0126 & 031 & 54 & 2 & 61 & 0 & 2 & 32 & 2 & 0062 \\
\hline & 40 & 10 & 0 & 0 & 8 & 2 & 0 & & & 0 & 092 \\
\hline k & 51 & 97 & 30 & 33 & 2 & 45 & 8 & $\perp$ & 0 & 0150 & 045 \\
\hline Wan & 51 & 55 & 330 & 063 & 155 & 053 & 58 & 8 & 00 & 30 & 053 \\
\hline IrElm & 059 & 123 & 029 & 0062 & 0.0138 & 0.0059 & 0.0057 & 0088 & 128 & 148 & 059 \\
\hline ite & 160 & 0.0168 & 129 & 0140 & 0.0303 & 308 & 0.0135 & 250 & 170 & 310 & 300 \\
\hline & 120 & 0130 & 150 & 095 & 180 & 190 & 30 & 5 & 25 & 90 & 190 \\
\hline $\mathrm{ac}$ & 114 & 0.0118 & 116 & 0124 & 180 & 185 & 105 & 0 & 137 & 195 & 186 \\
\hline$a r$ & 222 & 0.0226 & 0.0224 & 0.0226 & 229 & 200 & 0.0180 & 80 & 230 & 235 & 20 \\
\hline pe & 115 & 0.0125 & 0.0085 & 0090 & 0.0180 & 185 & 0.0070 & 35 & 997 & 90 & 85 \\
\hline 15 & 095 & 0.0100 & 0.0110 & 0110 & 120 & 200 & 30 & 5 & 0 & 5 & 200 \\
\hline & 84 & 5 & 3 & 94 & 6 & 173 & $\perp$ & 0.0071 & 5 & 0.0113 & \\
\hline $\mathrm{tm}$ & 0.0070 & 0072 & 071 & 72 & 074 & 0 & 53 & 3 & 2 & 4 & 200 \\
\hline Stm & 0098 & 0.0100 & 0.0099 & 0100 & 0.0123 & 0.0200 & 0.0080 & 80 & 00 & 5 & 200 \\
\hline $\mathrm{rrm}$ & 0.0100 & 0.0102 & 0.0100 & 0.0102 & 0.0125 & 0.0200 & 0.0085 & 585 & 02 & 130 & 200 \\
\hline$m$ & 080 & 0.0082 & 0081 & 0082 & 084 & 200 & 0.0072 & 2 & 82 & 87 & 200 \\
\hline Grs & 104 & $\mid 0.0107$ & 0.0106 & 0.0107 & 113 & 200 & 0.0094 & 110 & 107 & 115 & 200 \\
\hline Grs & 0095 & 0.0100 & 10 & 0 & 20 & 00 & 90 & 95 & 20 & 0.0125 & 200 \\
\hline pMuhly & 104 & 0.0111 & 0.0121 & 0.0132 & 37 & 00 & 0.0121 & 7 & 37 & 0 & 200 \\
\hline IBluStm & 100 & 0.0102 & 0.0100 & 0.0100 & 125 & 200 & 0.0080 & 1 & 05 & 0130 & 200 \\
\hline angrs & 102 & 0.0104 & 0.0102 & 102 & 26 & 220 & 0.0082 & 2 & 07 & 2 & 0 \\
\hline IDrpSd & 070 & 0.0080 & 0.0100 & 0.0104 & 0.0106 & 0.0200 & 0.0090 & 95 & 085 & $0 . U \perp \perp 0$ & 200 \\
\hline$x W n t G r s$ & 0120 & 0.0130 & 0.0130 & 0.0130 & 0.0135 & 0.0200 & 0.0120 & 0.0 & 0.0130 & 0.0140 & 200 \\
\hline CrlyMsqt & 0.0104 & 0.0107 & 0.0106 & 0.0107 & 0.0113 & 0.0200 & 0.0094 & 0.0110 & 0.0107 & 0.0115 & 0200 \\
\hline srmvva & 0.0104 & 0.0107 & 0.0106 & 0.0107 & 0.0113 & 0.0200 & 0.0054 & 0.0057 & 0.0110 & 0.0120 & $0.0<00$ \\
\hline VdSedge & 0.0095 & 0.0100 & 0.0110 & 0.0110 & 0.0120 & 0.0200 & 0.0105 & 0.0110 & 0.0115 & 0.0125 & 0.0200 \\
\hline RbtTbaco & 0.0190 & 0.0190 & 0.0190 & 0.0190 & 0.0198 & 0.0280 & 0.0102 & 0.0110 & 0.0296 & 0.0296 & 0.0280 \\
\hline PrrBluet & 0.0109 & 0.0113 & 0.0111 & 0.0113 & 0.0119 & 0.0200 & 0.0100 & 0.0105 & 0.0115 & 0.0125 & 0.0200 \\
\hline PrCnflwr & 0.0144 & 0.0146 & 0.0145 & 0.0146 & 0.0147 & 0.0200 & 0.0130 & 0.0135 & 0.0150 & 0.0160 & 0.0200 \\
\hline xSage & 0.0146 & 0.0148 & 0.0146 & 0.0148 & 0.0150 & 0.0210 & 0.0128 & 0.0132 & 0.0186 & 0.0188 & 0.0210 \\
\hline oveWeed & 0.0090 & 0.0100 & 0.0110 & 0.0130 & 0.0190 & 0.0250 & 0.0120 & 0.0150 & 0.0110 & 0.0200 & 0.0270 \\
\hline
\end{tabular}

Note: PlantNConc is the typical total $\mathrm{N}$ concentration for each component of each plant species.

SD: Standing Dead

Sdlg: Seedling 
Table B6. Required PlantNConc matrix.

\begin{tabular}{|c|c|c|c|c|c|c|c|c|c|c|c|c|}
\hline ecies & Min & Root & FRoot & unk & Stems & Leaves & Seeds & SDStems & SDLeaves & SdlgRoot & SdlgShoot & eedBa \\
\hline $\mathrm{HCl}$ & .75 & 060 & 125 & 030 & 063 & 140 & 060 & 0 & 90 & 0.0130 & .0150 & 60 \\
\hline Prsmmn & 75 & 062 & 126 & 031 & 64 & 142 & 61 & 50 & 92 & 0.0132 & 152 & 062 \\
\hline sheJunp & 0.75 & 0040 & 0.0110 & 0030 & 0040 & 0118 & 0.0092 & 030 & 0.0095 & 0.0120 & 120 & 0092 \\
\hline ShRdOak & 0.75 & 0051 & 0.0097 & 0.0030 & 063 & 0142 & 0.0045 & 58 & 0.0071 & 0.0100 & 150 & 045 \\
\hline Oak & 0.75 & 0051 & 0.0095 & 030 & 063 & 0155 & 53 & 58 & 078 & 0.0100 & 160 & 53 \\
\hline $\mathrm{drE} E \mathrm{Im}$ & 0.75 & 0059 & 0.0123 & 0029 & 062 & 0138 & 059 & 57 & 0.0088 & 0.0128 & 148 & 059 \\
\hline lesc & 0.75 & 0160 & 0.0168 & 0.0129 & 0.0140 & 0.0303 & 308 & 0.0135 & 0.0250 & 0.0170 & .0310 & .0300 \\
\hline otol & 0.75 & 0.0120 & 0.0130 & 0.0150 & 0.0095 & 0.0180 & 0.0190 & 0.0090 & 0.0095 & 0.0125 & 190 & 190 \\
\hline gS & 0.75 & 0114 & 0.0118 & 0.0116 & 0.0124 & 0.0180 & 0.0185 & 0.0105 & 0.0140 & 0.0137 & 195 & 186 \\
\hline iar & 0.75 & 0222 & 0.0226 & 0.0224 & 0.0226 & 0.0229 & 0.0200 & 0.0180 & 0.0180 & 0.0230 & 235 & 200 \\
\hline 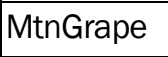 & 0.75 & 0115 & 0.0125 & 0.0085 & 0.0090 & 0.0180 & 0.0185 & 0.0070 & 0.0135 & 0.0097 & 0190 & 85 \\
\hline nnlGrs & 0.75 & 0095 & 0.0100 & 0.0110 & 0.0110 & 0.0120 & 0.0200 & 0.0090 & 0.0095 & 0.0120 & 0.0125 & 0 \\
\hline hrAn & 0.75 & 0084 & 0.0085 & 0.0093 & 0.0094 & 0.0096 & 0.0173 & 0.0071 & 0.0071 & 0.0085 & .0113 & 73 \\
\hline Stm & 0.75 & 0.0070 & 0.0072 & 0.0071 & 0.0072 & 0.0074 & 0.0200 & 0.0063 & 0.0063 & 0.0072 & 0.0074 & 0.0200 \\
\hline BluStm & 0.75 & 0098 & 0.0100 & 0.0099 & 0.0100 & 0.0123 & 0.0200 & 0.0080 & 0.0080 & 0.0100 & 0125 & 0.0200 \\
\hline dOtsGrm & 0.75 & 0.0100 & 0.0102 & 0.0100 & 0.0102 & 0.0125 & 0.0200 & 0.0085 & 0.0085 & 0.0102 & 130 & 0.0200 \\
\hline$y G r m$ & 0.75 & 0.0080 & 0.0082 & 0.0081 & 0.0082 & 0.0084 & 0.0200 & 0.0072 & 0.0072 & 0.0082 & 087 & 0.0200 \\
\hline mdaGrs & 0.75 & .0104 & 0.0107 & 0.0106 & 0.0107 & 0.0113 & 0.0200 & 0.0094 & 0.0110 & 0.0107 & 115 & 0.0200 \\
\hline xCupGrs & 0.75 & 0095 & 0.0100 & 0.0110 & 0.0110 & 0.0120 & 0.0200 & 0.0090 & 0.0095 & 0.0120 & 125 & 0.0200 \\
\hline pMuhly & 0.75 & 0.0104 & 0.0111 & 0.0121 & 0.0132 & 0.0137 & 0.0200 & 0.0121 & 0.0127 & 0.0137 & 140 & 0.0200 \\
\hline LIBluStm & 0.75 & 0.0100 & 0.0102 & 0.0100 & 0.0100 & 0.0125 & 0.0200 & 0.0080 & 0.0071 & 0.0105 & 30 & 0.0200 \\
\hline dnGrs & 0.75 & 0.0102 & 0.0104 & 0.0102 & 0.0102 & 0.0126 & 0.0220 & 0.0082 & 0.0072 & 0.0107 & 132 & 0.0220 \\
\hline TIDrpSd & 0.75 & 0.0070 & 0.0080 & 0.0100 & 0.0104 & 0.0106 & 0.0200 & 0.0090 & 0.0095 & 0.0085 & 0.0110 & 0.0200 \\
\hline TxWntGrs & 0.75 & 0.0120 & 0.0130 & 0.0130 & 0.0130 & 0.0135 & 0.0200 & 0.0120 & 0.0120 & 0.0130 & 0.0140 & 0.0200 \\
\hline CrlyMsqt & 0.75 & 0.0104 & 0.0107 & 0.0106 & 0.0107 & 0.0113 & 0.0200 & 0.0094 & 0.0110 & 0.0107 & 0.0115 & 0.0200 \\
\hline BrmWd & 0.75 & 0.0104 & 0.0107 & 0.0106 & 0.0107 & 0.0113 & 0.0200 & 0.0054 & 0.0057 & 0.0110 & 120 & 0.0200 \\
\hline WdSedge & 0.75 & 0.0095 & 0.0100 & 0.0110 & 0.0110 & 0.0120 & 0.0200 & 0.0105 & 10 & 0.0115 & 0.0125 & 0.0200 \\
\hline RbtTbaco & 0.75 & 0.0190 & 0.0190 & 0.0190 & 0.0190 & 98 & 0.0280 & 0.0102 & 10 & 0.0296 & 0.0296 & 0.0280 \\
\hline PrrBluet & 0.75 & 0.0109 & 0.0113 & 0.0111 & 0.0113 & 19 & 0.0200 & 0.0100 & 05 & 15 & 0.0125 & 0.0 \\
\hline PrCnflwr & 0.75 & 0.0144 & 0.0146 & 0.0145 & 0.0146 & 0.0147 & 0.0200 & 0.0130 & 35 & 0.0150 & 0.0160 & 0.0200 \\
\hline xSage & 0.75 & 0.0146 & 0.0148 & 0.0146 & 148 & 50 & 210 & 8 & 0. & 86 & 88 & 0.0 \\
\hline veWeed & .75 & 0090 & 0.0100 & 0.0110 & 0.0130 & 0.0190 & 0.0250 & 0.0120 & 0.0150 & 0.0110 & 0.0200 & 0.0270 \\
\hline
\end{tabular}

Note: Min is the minimum concentration needed for maintenance of plant biomass. Component values are minimum $\mathrm{N}$ concentrations needed for new growth. 
Table B7. Nitrogen resorption matrix.

\begin{tabular}{|c|c|c|c|c|c|c|}
\hline Species & CRoot & FRoot & Trunk & Stems & Leaves & Seeds \\
\hline NIHckbry & 0.15 & 0.10 & 0.00 & 0.15 & 0.20 & 0.00 \\
\hline TxPrsmmn & 0.15 & 0.10 & 0.00 & 0.15 & 0.20 & 0.00 \\
\hline AsheJunp & 0.15 & 0.10 & 0.00 & 0.15 & 0.20 & 0.00 \\
\hline ShRdOak & 0.15 & 0.10 & 0.00 & 0.15 & 0.20 & 0.00 \\
\hline LvOak & 0.15 & 0.10 & 0.00 & 0.15 & 0.20 & 0.00 \\
\hline CdrElm & 0.15 & 0.10 & 0.00 & 0.15 & 0.20 & 0.00 \\
\hline Mesquite & 0.10 & 0.05 & 0.00 & 0.05 & 0.10 & 0.00 \\
\hline Sotol & 0.10 & 0.05 & 0.00 & 0.05 & 0.10 & 0.00 \\
\hline EvgSumac & 0.10 & 0.05 & 0.00 & 0.05 & 0.20 & 0.00 \\
\hline GrnBriar & 0.10 & 0.05 & 0.00 & 0.10 & 0.20 & 0.00 \\
\hline MtnGrape & 0.10 & 0.05 & 0.00 & 0.05 & 0.20 & 0.00 \\
\hline AnnIGrs & 0.05 & 0.03 & 0.00 & 0.05 & 0.05 & 0.00 \\
\hline OfThrAn & 0.00 & 0.00 & 0.00 & 0.00 & 0.00 & 0.00 \\
\hline KRBluStm & 0.10 & 0.05 & 0.05 & 0.05 & 0.10 & 0.00 \\
\hline SiBluStm & 0.10 & 0.05 & 0.00 & 0.05 & 0.10 & 0.00 \\
\hline SdOtsGrm & 0.10 & 0.05 & 0.00 & 0.05 & 0.10 & 0.00 \\
\hline HryGrm & 0.05 & 0.03 & 0.00 & 0.05 & 0.05 & 0.00 \\
\hline BrmdaGrs & 0.05 & 0.03 & 0.05 & 0.05 & 0.05 & 0.00 \\
\hline TxCupGrs & 0.05 & 0.03 & 0.00 & 0.05 & 0.05 & 0.00 \\
\hline SpMuhly & 0.05 & 0.03 & 0.00 & 0.05 & 0.05 & 0.00 \\
\hline LIBluStm & 0.10 & 0.05 & 0.00 & 0.05 & 0.10 & 0.00 \\
\hline IndnGrs & 0.10 & 0.05 & 0.00 & 0.05 & 0.10 & 0.00 \\
\hline TIDrpSd & 0.10 & 0.05 & 0.00 & 0.05 & 0.10 & 0.00 \\
\hline TxWntGrs & 0.05 & 0.03 & 0.00 & 0.05 & 0.10 & 0.00 \\
\hline CrlyMsqt & 0.05 & 0.03 & 0.05 & 0.05 & 0.05 & 0.00 \\
\hline BrmWd & 0.00 & 0.00 & 0.00 & 0.00 & 0.00 & 0.00 \\
\hline WdSedge & 0.05 & 0.03 & 0.00 & 0.00 & 0.10 & 0.00 \\
\hline RbtTbaco & 0.00 & 0.00 & 0.00 & 0.00 & 0.00 & 0.00 \\
\hline PrrBluet & 0.05 & 0.03 & 0.00 & 0.05 & 0.10 & 0.00 \\
\hline PrCnflwr & 0.05 & 0.03 & 0.00 & 0.05 & 0.10 & 0.00 \\
\hline TxSage & 0.05 & 0.03 & 0.00 & 0.05 & 0.05 & 0.00 \\
\hline DoveWeed & 0.10 & 0.05 & 0.00 & 0.05 & 0.05 & 0.00 \\
\hline
\end{tabular}

Note: $\mathrm{N}$ resorption is the percentage of $\mathrm{N}$ withdrawn from a plant component before it incurs dieback. 
Table B8. Root architecture matrix.

\begin{tabular}{|c|c|c|c|c|c|c|c|c|c|c|c|c|c|}
\hline & \multicolumn{12}{|c|}{ Percent of Soil Profile Depth } & \multirow{2}{*}{\begin{tabular}{|l} 
Max. \\
Root \\
Depth \\
(cm)
\end{tabular}} \\
\hline Species & $0-1$ & $1-5$ & $5-10$ & $10-20$ & $20-30$ & $30-40$ & $40-50$ & $50-60$ & $60-70$ & 70-80 & $80-90$ & $90-100$ & \\
\hline NIHckbry & 0.02 & 0.06 & 0.08 & 0.15 & 0.10 & 0.15 & 0.13 & 0.1 & 0.1 & 0.06 & 0.03 & 0.02 & 10150 \\
\hline TxPrsmmn & 0.03 & 0.07 & 0.09 & 0.16 & 0.12 & 0.15 & 0.14 & 0.08 & 0.06 & 0.05 & 0.03 & 0.02 & 7300 \\
\hline AsheJunp & 0.02 & 0.06 & 0.08 & 0.15 & 0.11 & 0.15 & 0.14 & 0.09 & 0.09 & 0.06 & 0.03 & 0.02 & 12190 \\
\hline ShRdOak & 0.02 & 0.06 & 0.09 & 0.15 & 0.15 & 0.10 & 0.12 & 0.1 & 0.09 & 0.06 & 0.04 & 0.02 & 11500 \\
\hline LvOak & 0.02 & 0.06 & 0.08 & 0.15 & 0.11 & 0.15 & 0.14 & 0.09 & 0.09 & 0.06 & 0.02 & 0.02 & 7300 \\
\hline CdrElm & 0.02 & 0.06 & 0.09 & 0.15 & 0.12 & 0.15 & 0.12 & 0.1 & 0.08 & 0.06 & 0.03 & 0.02 & 7300 \\
\hline Mesquite & 0.04 & 0.06 & 0.15 & 0.20 & 0.15 & 0.12 & 0.10 & 0.06 & 0.05 & 0.03 & 0.02 & 0.02 & 24380 \\
\hline Sotol & 0.06 & 0.10 & 0.25 & 0.25 & 0.15 & 0.10 & 0.02 & 0.02 & 0.02 & 0.01 & 0.01 & 0.01 & 1080 \\
\hline EvgSumac & 0.04 & 0.06 & 0.20 & 0.16 & 0.12 & 0.10 & 0.08 & 0.07 & 0.07 & 0.06 & 0.03 & 0.01 & 1980 \\
\hline GrnBriar & 0.06 & 0.16 & 0.20 & 0.20 & 0.15 & 0.10 & 0.06 & 0.03 & 0.01 & 0.01 & 0.01 & 0.01 & 1500 \\
\hline MtnGrape & 0.10 & 0.12 & 0.25 & 0.20 & 0.20 & 0.05 & 0.03 & 0.01 & 0.01 & 0.01 & 0.01 & 0.01 & 1500 \\
\hline AnnlGrs & 0.20 & 0.20 & 0.24 & 0.14 & 0.10 & 0.04 & 0.03 & 0.01 & 0.01 & 0.01 & 0.01 & 0.01 & 40 \\
\hline OfThrAn & 0.20 & 0.20 & 0.20 & 0.14 & 0.10 & 0.06 & 0.04 & 0.02 & 0.01 & 0.01 & 0.01 & 0.01 & 1400 \\
\hline KRBluStm & 0.08 & 0.22 & 0.28 & 0.15 & 0.09 & 0.05 & 0.03 & 0.03 & 0.02 & 0.02 & 0.02 & 0.01 & 2400 \\
\hline SiBluStm & 0.12 & 0.34 & 0.27 & 0.08 & 0.06 & 0.04 & 0.03 & 0.02 & 0.01 & 0.01 & 0.01 & 0.01 & 2500 \\
\hline SdOtsGrm & 0.13 & 0.37 & 0.30 & 0.05 & 0.04 & 0.03 & 0.02 & 0.02 & 0.01 & 0.01 & 0.01 & 0.01 & 3960 \\
\hline HryGrm & 0.24 & 0.19 & 0.22 & 0.20 & 0.04 & 0.03 & 0.02 & 0.02 & 0.01 & 0.01 & 0.01 & 0.01 & 1070 \\
\hline BrmdaGrs & 0.22 & 0.20 & 0.22 & 0.20 & 0.04 & 0.03 & 0.03 & 0.02 & 0.01 & 0.01 & 0.01 & 0.01 & 1500 \\
\hline TxCupGrs & 0.20 & 0.20 & 0.24 & 0.14 & 0.10 & 0.04 & 0.03 & 0.01 & 0.01 & 0.01 & 0.01 & 0.01 & 940 \\
\hline SpMuhly & 0.20 & 0.20 & 0.18 & 0.15 & 0.10 & 0.06 & 0.05 & 0.02 & 0.01 & 0.01 & 0.01 & 0.01 & 1200 \\
\hline LIBluStm & 0.12 & 0.35 & 0.28 & 0.08 & 0.06 & 0.04 & 0.02 & 0.01 & 0.01 & 0.01 & 0.01 & 0.01 & 2440 \\
\hline IndnGrs & 0.20 & 0.25 & 0.20 & 0.12 & 0.08 & 0.05 & 0.04 & 0.02 & 0.01 & 0.01 & 0.01 & 0.01 & 2430 \\
\hline TIDrpSd & 0.09 & 0.21 & 0.23 & 0.12 & 0.10 & 0.08 & 0.06 & 0.04 & 0.03 & 0.02 & 0.02 & 0.01 & 2130 \\
\hline TxWntGrs & 0.08 & 0.08 & 0.11 & 0.14 & 0.12 & 0.12 & 0.12 & 0.07 & 0.06 & 0.05 & 0.03 & 0.02 & 1950 \\
\hline CrlyMsqt & 0.22 & 0.20 & 0.22 & 0.20 & 0.04 & 0.03 & 0.03 & 0.02 & 0.01 & 0.01 & 0.01 & 0.01 & 1830 \\
\hline BrmWd & 0.06 & 0.20 & 0.20 & 0.24 & 0.10 & 0.06 & 0.05 & 0.04 & 0.02 & 0.01 & 0.01 & 0.01 & 900 \\
\hline WdSedge & 0.20 & 0.20 & 0.20 & 0.14 & 0.10 & 0.06 & 0.04 & 0.02 & 0.01 & 0.01 & 0.01 & 0.01 & 1600 \\
\hline RbtTbaco & 0.06 & 0.15 & 0.18 & 0.26 & 0.10 & 0.08 & 0.05 & 0.04 & 0.03 & 0.02 & 0.02 & 0.01 & 1200 \\
\hline PrrBluet & 0.08 & 0.30 & 0.34 & 0.12 & 0.05 & 0.04 & 0.02 & 0.01 & 0.01 & 0.01 & 0.01 & 0.01 & 610 \\
\hline PrCnflwr & 0.09 & 0.30 & 0.40 & 0.10 & 0.03 & 0.02 & 0.01 & 0.01 & 0.01 & 0.01 & 0.01 & 0.01 & 1830 \\
\hline TxSage & 0.08 & 0.16 & 0.16 & 0.24 & 0.12 & 0.08 & 0.06 & 0.04 & 0.02 & 0.02 & 0.01 & 0.01 & 1560 \\
\hline DoveWeed & 0.08 & 0.30 & 0.34 & 0.12 & 0.05 & 0.04 & 0.02 & 0.01 & 0.01 & 0.01 & 0.01 & 0.01 & 610 \\
\hline
\end{tabular}

Note: Root architecture is the percentage of total root biomass by percentage of soil depth. Also included is the maximum rooting depth by species. 
Table B9. Root efficiency matrices.

\begin{tabular}{|c|c|c|c|}
\hline Species & Uptake Capacity & $\begin{array}{l}\text { Saturation Death } \\
\text { Loss }\end{array}$ & Biomass Adjustment \\
\hline NIHckbry & 0.1 & 0.60 & 0.90 \\
\hline TxPrsmmn & 0.1 & 0.65 & 1.00 \\
\hline AsheJunp & 0.1 & 0.60 & 1.00 \\
\hline ShRdOak & 0.1 & 0.60 & 1.00 \\
\hline LvOak & 0.1 & 0.60 & 1.00 \\
\hline CdrElm & 0.1 & 0.60 & 0.90 \\
\hline Mesquite & 0.1 & 0.60 & 1.00 \\
\hline Sotol & 0.1 & 0.80 & 1.00 \\
\hline EvgSumac & 0.1 & 0.75 & 1.00 \\
\hline GrnBriar & 0.1 & 0.85 & 1.00 \\
\hline MtnGrape & 0.1 & 0.75 & 1.00 \\
\hline AnnIGrs & 0.1 & 1.00 & 0.70 \\
\hline OfThrAn & 0.1 & 1.00 & 1.00 \\
\hline KRBluStm & 0.1 & 0.95 & 1.00 \\
\hline SiBluStm & 0.1 & 0.95 & 1.00 \\
\hline SdOtsGrm & 0.1 & 0.95 & 1.00 \\
\hline HryGrm & 0.1 & 1.00 & 1.00 \\
\hline BrmdaGrs & 0.1 & 1.00 & 0.90 \\
\hline TxCupGrs & 0.1 & 1.00 & 0.70 \\
\hline SpMuhly & 0.1 & 1.00 & 0.50 \\
\hline LIBluStm & 0.1 & 0.95 & 0.90 \\
\hline IndnGrs & 0.1 & 0.95 & 0.80 \\
\hline TIDrpSd & 0.1 & 0.95 & 1.00 \\
\hline TxWntGrs & 0.1 & 1.00 & 1.00 \\
\hline CrlyMsqt & 0.1 & 1.00 & 1.00 \\
\hline BrmWd & 0.1 & 0.90 & 1.00 \\
\hline WdSedge & 0.1 & 1.00 & 1.00 \\
\hline RbtTbaco & 0.1 & 0.95 & 1.00 \\
\hline PrrBluet & 0.1 & 0.10 & 0.90 \\
\hline PrCnflwr & 0.1 & 0.95 & 1.00 \\
\hline TxSage & 0.1 & 0.95 & 1.00 \\
\hline DoveWeed & 0.2 & 0.75 & 1.00 \\
\hline
\end{tabular}

Note: Uptake Capacity is the proportion of total monthly water demand that can be taken up in one day. Biomass Adjustment is relative per biomass uptake efficiency of roots of each species. Maximum is 1. 
Table B10. Physiological month triggers.

\begin{tabular}{|c|c|c|c|c|c|c|}
\hline \multirow[b]{2}{*}{ Species } & \multirow[b]{2}{*}{ Green-out } & \multicolumn{2}{|c|}{ Seed Sprout } & \multicolumn{2}{|c|}{ Seed Set } & \multirow[b]{2}{*}{ Dormancy } \\
\hline & & Start & End & Start & End & \\
\hline NIHckbry & 3 & 3 & 9 & 4 & 8 & 10 \\
\hline TxPrsmmn & 2 & 2 & 9 & 3 & 8 & 10 \\
\hline AsheJunp & 1 & 3 & 9 & 3 & 7 & 1 \\
\hline ShRdOak & 3 & 3 & 8 & 4 & 8 & 10 \\
\hline LvOak & 2 & 3 & 9 & 4 & 8 & 2 \\
\hline CdrElm & 3 & 3 & 8 & 4 & 8 & 10 \\
\hline Mesquite & 4 & 3 & 9 & 4 & 8 & 10 \\
\hline Sotol & 1 & 2 & 10 & 6 & 7 & 1 \\
\hline EvgSumac & 1 & 3 & 9 & 4 & 8 & 1 \\
\hline GrnBriar & 9 & 9 & 6 & 2 & 6 & 7 \\
\hline MtnGrape & 2 & 3 & 9 & 6 & 10 & 11 \\
\hline AnnIGrs & 2 & 3 & 8 & 3 & 11 & 11 \\
\hline OfThrAn & 3 & 3 & 10 & 8 & 11 & 11 \\
\hline KRBluStm & 3 & 3 & 9 & 7 & 10 & 12 \\
\hline SiBluStm & 4 & 3 & 8 & 5 & 9 & 11 \\
\hline SdOtsGrm & 3 & 3 & 8 & 6 & 10 & 11 \\
\hline HryGrm & 3 & 3 & 8 & 6 & 10 & 11 \\
\hline BrmdaGrs & 3 & 3 & 8 & 5 & 10 & 11 \\
\hline TxCupGrs & 2 & 3 & 8 & 3 & 11 & 11 \\
\hline SpMuhly & 3 & 4 & 9 & 8 & 11 & 11 \\
\hline LIBluStm & 4 & 3 & 8 & 8 & 10 & 11 \\
\hline IndnGrs & 3 & 3 & 8 & 8 & 11 & 11 \\
\hline TIDrpSd & 4 & 3 & 8 & 9 & 11 & 11 \\
\hline TxWntGrs & 9 & 9 & 3 & 3 & 5 & 7 \\
\hline CrlyMsqt & 3 & 3 & 8 & 5 & 10 & 11 \\
\hline BrmWd & 3 & 3 & 8 & 6 & 9 & 10 \\
\hline WdSedge & 3 & 4 & 9 & 5 & 9 & 11 \\
\hline RbtTbaco & 2 & 2 & 6 & 3 & 5 & 7 \\
\hline PrrBluet & 3 & 3 & 8 & 4 & 9 & 11 \\
\hline PrCnflwr & 3 & 3 & 8 & 5 & 9 & 11 \\
\hline TxSage & 2 & 2 & 6 & 3 & 5 & 7 \\
\hline DoveWeed & 2 & 3 & 9 & 4 & 8 & 11 \\
\hline
\end{tabular}

Note: Green-out is the month in which the species greens out from winter dormancy.

Seed sprout is the interval of months in which seeds in the Seed Bank can sprout, given appropriate water conditions.

Seed set is the interval of months in which mature plants produce seed, and the SeedMonthAllocation matrix is used.

Dormancy is the month in which the species enters winter dormancy. 
Table B11. Biomass conversion constants.

\begin{tabular}{|c|c|c|c|}
\hline Species & Dry wt/Wet wt & $\begin{array}{l}\text { Moisture Interception } \\
\text { g biomass }\end{array}$ & \begin{tabular}{|l} 
Basal Cover/ \\
Trunk Biomass
\end{tabular} \\
\hline NIHckbry & 0.55 & 0.0089 & 1310 \\
\hline TxPrsmmn & 0.55 & 0.0080 & 730 \\
\hline AsheJunp & 0.55 & 0.0090 & 254 \\
\hline ShRdOak & 0.55 & 0.0090 & 1848 \\
\hline LvOak & 0.55 & 0.0092 & 696 \\
\hline CdrElm & 0.55 & 0.0087 & 1310 \\
\hline Mesquite & 0.50 & 0.0090 & 500 \\
\hline Sotol & 0.40 & 0.0085 & 20 \\
\hline EvgSumac & 0.35 & 0.0090 & 20 \\
\hline GrnBriar & 0.39 & 0.0080 & 3 \\
\hline MtnGrape & 0.30 & 0.0080 & 10 \\
\hline AnnIGrs & 0.34 & 0.0084 & 2 \\
\hline OfThrAn & 0.35 & 0.0084 & 1 \\
\hline KRBluStm & 0.33 & 0.0085 & 3 \\
\hline SiBluStm & 0.34 & 0.0086 & 3 \\
\hline SdOtsGrm & 0.34 & 0.0086 & 4 \\
\hline HryGrm & 0.35 & 0.0083 & 2 \\
\hline BrmdaGrs & 0.36 & 0.0084 & 2 \\
\hline TxCupGrs & 0.34 & 0.0084 & 2 \\
\hline SpMuhly & 0.34 & 0.0082 & 1 \\
\hline LIBluStm & 0.35 & 0.0086 & 3 \\
\hline IndnGrs & 0.36 & 0.0088 & 4 \\
\hline TIDrpSd & 0.35 & 0.0086 & 3 \\
\hline TxWntGrs & 0.34 & 0.0084 & 2 \\
\hline CrlyMsqt & 0.36 & 0.0084 & 2 \\
\hline BrmWd & 0.40 & 0.0080 & 1 \\
\hline WdSedge & 0.33 & 0.0085 & 1 \\
\hline RbtTbaco & 0.30 & 0.0088 & 1 \\
\hline PrrBluet & 0.30 & 0.0082 & 3 \\
\hline PrCnflwr & 0.33 & 0.0083 & 3 \\
\hline TxSage & 0.30 & 0.0084 & 2 \\
\hline DoveWeed & 0.18 & 0.0050 & 40 \\
\hline
\end{tabular}

Note: Dry wt / Wet wt is the typical ratio of dry biomass to wet biomass.

Moisture Interception is the precipitation depth $(\mathrm{mm})$ intercepted by the species per $g$ aboveground biomass.

Basal cover / Trunk biomass is the area of trunk $\left(\mathrm{cm}^{2} / \mathrm{m}^{2}\right)$ covered by the species per $\mathrm{g}$ of trunk biomass. 
Table B12. Water use factors.

\begin{tabular}{|c|c|c|c|c|}
\hline Species & $\begin{array}{l}\text { Maintenance } \\
(\mathrm{mm} / \mathrm{g} \text { bio/mo })\end{array}$ & $\begin{array}{l}\text { New Biomass } \\
\text { Maintenance }\end{array}$ & $\begin{array}{l}\text { Water to } \\
\text { Production }\end{array}$ & $\begin{array}{l}\text { Green-out } \\
\text { Water Use }\end{array}$ \\
\hline NIHckbry & 0.0000090 & 0.05 & 0.92 & 0.45 \\
\hline TxPrsmmn & 0.0000080 & 0.04 & 0.64 & 0.45 \\
\hline AsheJunp & 0.0000065 & 0.03 & 0.53 & 0.45 \\
\hline ShRdOak & 0.0000085 & 0.04 & 0.90 & 0.45 \\
\hline LvOak & 0.0000080 & 0.04 & 0.80 & 0.45 \\
\hline CdrElm & 0.0000090 & 0.05 & 0.92 & 0.45 \\
\hline Mesquite & 0.0000095 & 0.05 & 1.30 & 0.50 \\
\hline Sotol & 0.0000075 & 0.04 & 0.51 & 0.60 \\
\hline EvgSumac & 0.0000090 & 0.05 & 0.54 & 0.65 \\
\hline GrnBriar & 0.0000180 & 0.05 & 1.08 & 0.61 \\
\hline MtnGrape & 0.0000090 & 0.05 & 1.08 & 0.70 \\
\hline AnnIGrs & 0.0000180 & 0.05 & 0.55 & 0.66 \\
\hline OfThrAn & 0.0000150 & 0.04 & 0.56 & 0.65 \\
\hline KRBluStm & 0.0000150 & 0.04 & 0.68 & 0.67 \\
\hline SiBluStm & 0.0000170 & 0.06 & 0.71 & 0.66 \\
\hline SdOtsGrm & 0.0000160 & 0.04 & 0.75 & 0.66 \\
\hline HryGrm & 0.0000160 & 0.04 & 0.41 & 0.65 \\
\hline BrmdaGrs & 0.0000136 & 0.03 & 0.31 & 0.64 \\
\hline TxCupGrs & 0.0000180 & 0.05 & 0.55 & 0.66 \\
\hline SpMuhly & 0.0000160 & 0.05 & 0.92 & 0.66 \\
\hline LIBluStm & 0.0000170 & 0.06 & 0.70 & 0.65 \\
\hline IndnGrs & 0.0000175 & 0.06 & 0.83 & 0.64 \\
\hline TIDrpSd & 0.0000170 & 0.06 & 0.71 & 0.65 \\
\hline TxWntGrs & 0.0000200 & 0.06 & 0.99 & 0.66 \\
\hline CrlyMsqt & 0.0000150 & 0.04 & 0.43 & 0.64 \\
\hline BrmWd & 0.0000180 & 0.05 & 0.42 & 0.60 \\
\hline WdSedge & 0.0000200 & 0.06 & 0.79 & 0.67 \\
\hline RbtTbaco & 0.0000200 & 0.05 & 0.86 & 0.70 \\
\hline PrrBluet & 0.0000200 & 0.07 & 0.59 & 0.70 \\
\hline PrCnflwr & 0.0000190 & 0.06 & 0.70 & 0.67 \\
\hline TxSage & 0.0000220 & 0.04 & 0.65 & 0.70 \\
\hline DoveWeed & 0.0000250 & 0.08 & 0.65 & 0.82 \\
\hline
\end{tabular}

Note: Maintenance is the volume of water $(\mathrm{mm})$ required for monthly physiological maintenance per $\mathrm{g}$ biomass.

New biomass maintenance is volume of water $(\mathrm{mm})$ required for monthly physiological maintenance per g biomass for new (green-out) biomass.

Water to production is the volume of water $(\mathrm{mm})$ required to produce $1 \mathrm{~g}$ of new biomass.

Green-out water use is a factor for adjusting water to production during green-out months. 
Table B13. Growth rates.

\begin{tabular}{|c|c|c|c|}
\hline Species & Maximum Growth Rate & Maximum Biomass & $\begin{array}{l}\text { Maximum Old Biomass } \\
\text { Drought Loss }\end{array}$ \\
\hline NIHckbry & 0.30 & 8000 & 0.35 \\
\hline TxPrsmmn & 0.20 & 5000 & 0.20 \\
\hline AsheJunp & 0.20 & 12000 & 0.25 \\
\hline ShRdOak & 0.20 & 12000 & 0.30 \\
\hline LvOak & 0.15 & 15000 & 0.25 \\
\hline CdrElm & 0.30 & 9000 & 0.35 \\
\hline Mesquite & 0.30 & 10000 & 0.30 \\
\hline Sotol & 0.20 & 1200 & 0.15 \\
\hline EvgSumac & 0.75 & 2000 & 0.30 \\
\hline GrnBriar & 0.40 & 800 & 0.40 \\
\hline MtnGrape & 0.40 & 2500 & 0.35 \\
\hline AnnIGrs & 1.70 & 600 & 0.40 \\
\hline OfThrAn & 1.75 & 400 & 0.40 \\
\hline KRBluStm & 1.50 & 540 & 0.30 \\
\hline SiBluStm & 1.40 & 600 & 0.40 \\
\hline SdOtsGrm & 1.50 & 600 & 0.40 \\
\hline HryGrm & 1.50 & 200 & 0.40 \\
\hline BrmdaGrs & 1.71 & 450 & 0.30 \\
\hline TxCupGrs & 1.70 & 600 & 0.40 \\
\hline SpMuhly & 1.50 & 400 & 0.40 \\
\hline LIBluStm & 1.50 & 650 & 0.40 \\
\hline IndnGrs & 1.50 & 750 & 0.40 \\
\hline TIDrpSd & 1.40 & 600 & 0.40 \\
\hline TxWntGrs & 1.75 & 450 & 0.30 \\
\hline CrlyMsqt & 1.25 & 250 & 0.30 \\
\hline BrmWd & 2.20 & 300 & 0.50 \\
\hline WdSedge & 1.40 & 250 & 0.50 \\
\hline RbtTbaco & 1.80 & 150 & 0.50 \\
\hline PrrBluet & 1.80 & 200 & 0.60 \\
\hline PrCnflwr & 1.80 & 500 & 0.40 \\
\hline TxSage & 1.80 & 400 & 0.40 \\
\hline DoveWeed & 1.50 & 300 & 0.80 \\
\hline
\end{tabular}

Note: Maximum growth rate is the maximum monthly percent increase in biomass.

Maximum old biomass drought loss is the maximum monthly percent decrease in old biomass due to drought stress. 
Table B14. Monthly maximum growth rates.

\begin{tabular}{|c|c|c|c|c|c|c|c|c|c|c|c|c|}
\hline Species & Jan & Feb & Mar & Apr & May & Jun & Jul & Aug & Sep & Oct & Nov & Dec \\
\hline NIHckbry & 0.00 & 0.20 & 0.40 & 0.80 & 1.00 & 1.00 & 1.00 & 1.00 & 0.90 & 0.50 & 0.20 & 0.00 \\
\hline TxPrsmmn & .00 & 0.20 & 0.40 & 0.80 & 1.00 & 1.00 & 1.00 & 1.00 & 0.90 & 0.50 & 0.20 & 0.00 \\
\hline AsheJunp & 0.50 & 0.50 & 0.70 & 0.90 & 1.00 & 1.00 & 1.00 & 1.00 & 1.00 & 1.00 & 0.80 & 0.70 \\
\hline ShRdOak & 0.00 & 0.00 & 0.40 & 0.80 & 1.00 & 1.00 & 1.00 & 1.00 & 0.80 & 0.40 & 0.10 & 0.00 \\
\hline LvOak & 0.30 & 0.40 & 0.70 & 0.90 & 1.00 & 1.00 & 1.00 & 1.00 & 1.00 & 0.90 & 0.70 & 0.50 \\
\hline CdrElm & 0.00 & 0.10 & 0.50 & 0.90 & 1.00 & 1.00 & 1.00 & 1.00 & 0.80 & 0.40 & 0.10 & 0.00 \\
\hline Mesquite & 0.00 & 0.00 & 0.00 & 0.50 & 0.90 & 1.00 & 1.00 & 1.00 & 0.90 & 0.50 & 0.00 & 0.00 \\
\hline Sotol & 0.40 & 0.40 & 0.70 & 1.00 & 1.00 & 1.00 & 1.00 & 1.00 & 1.00 & 0.80 & 0.60 & 0.40 \\
\hline EvgSumac & 0.20 & 0.20 & 0.40 & 0.80 & 1.00 & 1.00 & 1.00 & 1.00 & 0.90 & 0.60 & 0.30 & 0.20 \\
\hline GrnBriar & 0.50 & 0.50 & 0.80 & 1.00 & 1.00 & 0.80 & 0.40 & 0.00 & 0.40 & 1.00 & 1.00 & 0.50 \\
\hline MtnGrape & 0.00 & 0.10 & 0.60 & 1.00 & 1.00 & 1.00 & 1.00 & 1.00 & 0.80 & 0.60 & 0.20 & 0.00 \\
\hline AnnIGrs & 0.00 & 0.10 & 0.60 & 0.90 & 1.00 & 1.00 & 1.00 & 1.00 & 0.80 & 0.40 & 0.20 & 0.00 \\
\hline OfThrAn & 0.00 & 0.10 & 0.50 & 0.90 & 1.00 & 1.00 & 1.00 & 1.00 & 0.70 & 0.30 & 0.10 & 0.00 \\
\hline KRBluStm & 0.00 & 0.00 & 0.50 & 0.90 & 1.00 & 1.00 & 1.00 & 1.00 & 1.00 & 0.70 & 0.40 & 0.00 \\
\hline SiBluStm & 0.00 & 0.00 & 0.50 & 0.90 & 1.00 & 1.00 & 1.00 & 1.00 & 0.90 & 0.50 & 0.20 & 0.00 \\
\hline SdOtsGrm & 0.00 & 0.00 & 0.50 & 0.80 & 0.95 & 1.00 & 1.00 & 1.00 & 0.95 & 0.60 & 0.30 & 0.00 \\
\hline HryGrm & 0.00 & 0.00 & 0.40 & 0.80 & 1.00 & 1.00 & 1.00 & 1.00 & 0.90 & 0.50 & 0.30 & 0.00 \\
\hline BrmdaGrs & 0.00 & 0.00 & 0.50 & 0.90 & 1.00 & 1.00 & 1.00 & 1.00 & 1.00 & 0.70 & 0.40 & 0.00 \\
\hline TxCupGrs & 0.00 & 0.10 & 0.60 & 0.90 & 1.00 & 1.00 & 1.00 & 1.00 & 0.80 & 0.40 & 0.20 & 0.00 \\
\hline SpMuhly & 0.00 & 0.10 & 0.50 & 0.90 & 1.00 & 1.00 & 1.00 & 1.00 & 0.80 & 0.60 & 0.10 & 0.00 \\
\hline LIBluStm & 0.00 & 0.00 & 0.50 & 0.90 & 1.00 & 1.00 & 1.00 & 1.00 & 0.90 & 0.50 & 0.20 & 0.00 \\
\hline IndnGrs & 0.00 & 0.00 & 0.40 & 0.80 & 0.90 & 1.00 & 1.00 & 1.00 & 0.80 & 0.40 & 0.20 & 0.00 \\
\hline TIDrpSd & 0.00 & 0.00 & 0.00 & 0.50 & 1.00 & 1.00 & 1.00 & 1.00 & 0.90 & 0.50 & 0.20 & 0.00 \\
\hline TxWntGrs & 0.80 & 0.90 & 1.00 & 1.00 & 0.80 & 0.50 & 0.20 & 0.00 & 0.40 & 1.00 & 1.00 & 0.90 \\
\hline CrlyMsqt & 0.00 & 0.00 & 0.50 & 0.90 & 1.00 & 1.00 & 1.00 & 1.00 & 1.00 & 0.70 & 0.40 & 0.00 \\
\hline BrmWd & 0.00 & 0.10 & 0.40 & 0.80 & 1.00 & 1.00 & 1.00 & 1.00 & 0.80 & 0.30 & 0.00 & 0.00 \\
\hline WdSedge & 0.00 & 0.10 & 0.50 & 0.80 & 1.00 & 1.00 & 1.00 & 1.00 & 0.80 & 0.70 & 0.30 & 0.00 \\
\hline RbtTbaco & 0.00 & 0.30 & 0.70 & 1.00 & 1.00 & 0.90 & 0.60 & 0.30 & 0.10 & 0.10 & 0.00 & 0.00 \\
\hline PrrBluet & 0.00 & 0.00 & 0.30 & 0.60 & 0.90 & 1.00 & 1.00 & 1.00 & 0.80 & 0.50 & 0.20 & 0.00 \\
\hline PrCnflwr & 0.00 & 0.00 & 0.40 & 0.90 & 1.00 & 1.00 & 1.00 & 1.00 & 0.80 & 0.50 & 0.20 & 0.00 \\
\hline TxSage & 0.00 & 0.00 & 0.40 & 0.80 & 1.00 & 1.00 & 0.80 & 0.60 & 0.40 & 0.20 & 0.10 & 0.00 \\
\hline DoveWeed & 0.10 & 0.10 & 0.40 & 0.80 & 1.00 & 1.00 & 1.00 & 1.00 & 0.90 & 0.40 & 0.20 & 0.10 \\
\hline
\end{tabular}

Note: Monthly maximum growth rate is the monthly adjustment factor for maximum growth rate. 
Table B15. Plant part productivity.

\begin{tabular}{|c|c|c|c|c|c|c|}
\hline Species & CRoot & FRoot & Trunk & Stems & Leaves & Seeds \\
\hline NIHckbry & 0.00 & 0.00 & 0.00 & 0.10 & 1.00 & 0.00 \\
\hline TxPrsmmn & 0.00 & 0.00 & 0.00 & 0.10 & 1.00 & 0.00 \\
\hline AsheJunp & 0.00 & 0.00 & 0.00 & 0.10 & 1.00 & 0.00 \\
\hline ShRdOak & 0.00 & 0.00 & 0.00 & 0.00 & 1.00 & 0.00 \\
\hline LvOak & 0.00 & 0.00 & 0.00 & 0.00 & 1.00 & 0.00 \\
\hline CdrElm & 0.00 & 0.00 & 0.00 & 0.00 & 1.00 & 0.00 \\
\hline Mesquite & 0.00 & 0.00 & 0.00 & 0.10 & 1.00 & 0.10 \\
\hline Sotol & 0.00 & 0.00 & 0.10 & 0.20 & 1.00 & 0.00 \\
\hline EvgSumac & 0.00 & 0.00 & 0.00 & 0.30 & 1.00 & 0.00 \\
\hline GrnBriar & 0.00 & 0.00 & 0.10 & 0.50 & 1.00 & 0.00 \\
\hline MtnGrape & 0.00 & 0.00 & 0.00 & 0.10 & 1.00 & 0.00 \\
\hline AnnIGrs & 0.00 & 0.00 & 0.10 & 0.30 & 1.00 & 0.00 \\
\hline OfThrAn & 0.00 & 0.00 & 0.10 & 0.20 & 1.00 & 0.00 \\
\hline KRBluStm & 0.00 & 0.00 & 0.20 & 0.40 & 1.00 & 0.00 \\
\hline SiBluStm & 0.00 & 0.00 & 0.10 & 0.20 & 1.00 & 0.00 \\
\hline SdOtsGrm & 0.00 & 0.00 & 0.10 & 0.30 & 1.00 & 0.00 \\
\hline HryGrm & 0.00 & 0.00 & 0.10 & 0.30 & 1.00 & 0.00 \\
\hline BrmdaGrs & 0.00 & 0.00 & 0.20 & 0.30 & 1.00 & 0.00 \\
\hline TxCupGrs & 0.00 & 0.00 & 0.10 & 0.30 & 1.00 & 0.00 \\
\hline SpMuhly & 0.00 & 0.00 & 0.10 & 0.20 & 1.00 & 0.00 \\
\hline LIBluStm & 0.00 & 0.00 & 0.10 & 0.20 & 1.00 & 0.00 \\
\hline IndnGrs & 0.00 & 0.00 & 0.10 & 0.20 & 1.00 & 0.00 \\
\hline TIDrpSd & 0.00 & 0.00 & 0.10 & 0.20 & 1.00 & 0.00 \\
\hline TxWntGrs & 0.00 & 0.00 & 0.20 & 0.30 & 1.00 & 0.00 \\
\hline CrlyMsqt & 0.00 & 0.00 & 0.20 & 0.30 & 1.00 & 0.00 \\
\hline BrmWd & 0.00 & 0.00 & 0.00 & 0.10 & 1.00 & 0.00 \\
\hline WdSedge & 0.00 & 0.00 & 0.00 & 0.20 & 1.00 & 0.00 \\
\hline RbtTbaco & 0.00 & 0.00 & 0.10 & 0.20 & 1.00 & 0.00 \\
\hline PrrBluet & 0.00 & 0.00 & 0.20 & 0.20 & 1.00 & 0.00 \\
\hline PrCnflwr & 0.00 & 0.00 & 0.10 & 0.20 & 1.00 & 0.00 \\
\hline TxSage & 0.00 & 0.00 & 0.10 & 0.20 & 1.00 & 0.00 \\
\hline DoveWeed & 0.00 & 0.00 & 0.00 & 0.30 & 1.00 & 0.00 \\
\hline
\end{tabular}

Note: Plant part productivity is the relative productivity adjustment factor for different plant parts in calculating absolute growth percentage (effectively, photosynthetic biomass). 
Table B16. Green-out plant part productivity.

\begin{tabular}{|c|c|c|c|c|c|c|}
\hline Species & CRoot & FRoot & Trunk & Stems & Leaves & Seeds \\
\hline NIHckbry & 0.01 & 0.00 & 0.03 & 0.05 & 0.75 & 0.00 \\
\hline TxPrsmmn & 0.01 & 0.00 & 0.03 & 0.05 & 0.75 & 0.00 \\
\hline AsheJunp & 0.01 & 0.00 & 0.02 & 0.05 & 0.75 & 0.00 \\
\hline ShRdOak & 0.01 & 0.00 & 0.02 & 0.05 & 0.75 & 0.00 \\
\hline LvOak & 0.01 & 0.00 & 0.02 & 0.05 & 0.75 & 0.00 \\
\hline CdrElm & 0.01 & 0.00 & 0.03 & 0.10 & 0.75 & 0.00 \\
\hline Mesquite & 0.10 & 0.00 & 0.04 & 0.10 & 0.80 & 0.00 \\
\hline Sotol & 0.05 & 0.00 & 0.10 & 0.30 & 1.00 & 0.00 \\
\hline EvgSumac & 0.05 & 0.00 & 0.05 & 0.20 & 1.00 & 0.00 \\
\hline GrnBriar & 0.10 & 0.00 & 0.20 & 0.50 & 1.00 & 0.00 \\
\hline MtnGrape & 0.05 & 0.00 & 0.10 & 0.20 & 1.00 & 0.00 \\
\hline AnnIGrs & 0.05 & 0.00 & 0.10 & 0.50 & 1.00 & 0.00 \\
\hline OfThrAn & 0.00 & 0.00 & 0.50 & 0.50 & 1.00 & 0.00 \\
\hline KRBluStm & 0.10 & 0.00 & 0.20 & 0.50 & 1.00 & 0.00 \\
\hline SiBluStm & 0.05 & 0.00 & 0.10 & 0.50 & 1.00 & 0.00 \\
\hline SdOtsGrm & 0.10 & 0.00 & 0.20 & 0.50 & 1.00 & 0.00 \\
\hline HryGrm & 0.05 & 0.00 & 0.10 & 0.50 & 1.00 & 0.00 \\
\hline BrmdaGrs & 0.10 & 0.00 & 0.10 & 0.50 & 1.00 & 0.00 \\
\hline TxCupGrs & 0.05 & 0.00 & 0.10 & 0.50 & 1.00 & 0.00 \\
\hline SpMuhly & 0.05 & 0.00 & 0.10 & 0.50 & 1.00 & 0.00 \\
\hline LIBluStm & 0.05 & 0.00 & 0.10 & 0.50 & 1.00 & 0.00 \\
\hline IndnGrs & 0.10 & 0.00 & 0.10 & 0.50 & 1.00 & 0.00 \\
\hline TIDrpSd & 0.05 & 0.00 & 0.10 & 0.50 & 1.00 & 0.00 \\
\hline TxWntGrs & 0.05 & 0.00 & 0.15 & 0.50 & 1.00 & 0.00 \\
\hline CrlyMsqt & 0.05 & 0.00 & 0.10 & 0.50 & 1.00 & 0.00 \\
\hline BrmWd & 0.00 & 0.00 & 0.05 & 0.50 & 1.00 & 0.00 \\
\hline WdSedge & 0.10 & 0.00 & 0.30 & 0.50 & 1.00 & 0.00 \\
\hline RbtTbaco & 0.00 & 0.00 & 0.20 & 0.50 & 1.00 & 0.00 \\
\hline PrrBluet & 0.10 & 0.00 & 0.10 & 0.50 & 1.00 & 0.00 \\
\hline PrCnflwr & 0.10 & 0.00 & 0.10 & 0.50 & 1.00 & 0.00 \\
\hline TxSage & 0.00 & 0.00 & 0.20 & 0.50 & 1.00 & 0.00 \\
\hline DoveWeed & 0.20 & 0.00 & 0.40 & 0.40 & 1.00 & 0.00 \\
\hline
\end{tabular}

Note: Green-out plant part productivity is plant part productivity used during green-out months. 
Table B17. Light competition factors.

\begin{tabular}{|c|c|c|c|c|c|c|c|c|}
\hline Species & NIHckbry & TxPrsmn & AsheJunp & ShRdOak & LvOak & CdrElm & Mesquite & Soto \\
\hline NIHckbry & 0.00 & 0.00 & 0.00 & 0.00 & 0.05 & 0.00 & 0.00 & 0.00 \\
\hline TxPrsmmn & 0.05 & 0.00 & 0.00 & 0.05 & 0.10 & 0.05 & 0.00 & 0.00 \\
\hline AsheJunp & 1.00 & 0.00 & 0.00 & 1.00 & 1.00 & 1.00 & 0.00 & 0.00 \\
\hline ShRdOak & 0.00 & 0.00 & 0.00 & 0.00 & 0.10 & 0.00 & 0.00 & 0.00 \\
\hline LvOak & 0.00 & 0.00 & 0.00 & 0.00 & 0.00 & 0.00 & 0.00 & 0.00 \\
\hline CdrElm & 0.00 & 0.00 & 0.00 & 0.00 & 0.05 & 0.00 & 0.00 & 0.00 \\
\hline Mesquite & 0.50 & 0.00 & 0.40 & 0.50 & 1.00 & 0.50 & 0.00 & 0.00 \\
\hline Sotol & 0.20 & 0.20 & 0.10 & 0.25 & 0.50 & 0.20 & 0.10 & 0.00 \\
\hline EvgSumac & 0.05 & 0.02 & 0.04 & 0.05 & 0.20 & 0.04 & 0.10 & 0.00 \\
\hline GrnBriar & 0.05 & 0.03 & 0.05 & 0.10 & 0.15 & 0.03 & 0.10 & 0.00 \\
\hline MtnGrape & 0.00 & 0.00 & 0.00 & 0.00 & 0.00 & 0.00 & 0.00 & 0.00 \\
\hline AnnIGrs & 0.03 & 0.02 & 0.08 & 0.04 & 0.06 & 0.02 & 0.04 & 0.02 \\
\hline OfThrAn & 0.12 & 0.10 & 0.05 & 0.12 & 0.16 & 0.10 & 0.06 & 0.08 \\
\hline KRBluStm & 0.08 & 0.06 & 0.03 & 0.08 & 0.12 & 0.06 & 0.04 & 0.04 \\
\hline SiBluStm & 0.08 & 0.06 & 0.03 & 0.08 & 0.12 & 0.06 & 0.04 & 0.00 \\
\hline SdOtsGrm & 0.06 & 0.04 & 0.03 & 0.08 & 0.10 & 0.04 & 0.04 & 0.00 \\
\hline HryGrm & 0.12 & 0.10 & 0.04 & 0.12 & 0.16 & 0.10 & 0.08 & 0.08 \\
\hline BrmdaGrs & 0.12 & 0.10 & 0.04 & 0.12 & 0.16 & 0.10 & 0.08 & 0.08 \\
\hline TxCupGrs & 0.03 & 0.02 & 0.02 & 0.04 & 0.06 & 0.02 & 0.04 & 0.02 \\
\hline SpMuhly & 0.04 & 0.04 & 0.02 & 0.04 & 0.08 & 0.02 & 0.04 & 0.01 \\
\hline LIBluStm & 0.04 & 0.04 & 0.03 & 0.04 & 0.04 & 0.04 & 0.04 & 0.00 \\
\hline IndnGrs & 0.06 & 0.04 & 0.02 & 0.08 & 0.10 & 0.04 & 0.04 & 0.00 \\
\hline TIDrpSd & 0.04 & 0.02 & 0.03 & 0.06 & 0.08 & 0.02 & 0.04 & 0.00 \\
\hline TxWntGrs & 0.00 & 0.00 & 0.03 & 0.00 & 0.04 & 0.00 & 0.00 & 0.00 \\
\hline CrlyMsqt & 0.12 & 0.10 & 0.04 & 0.12 & 0.16 & 0.10 & 0.08 & 0.08 \\
\hline BrmWd & 0.08 & 0.06 & 0.04 & 0.10 & 0.12 & 0.06 & 0.00 & 0.04 \\
\hline WdSedge & 0.04 & 0.04 & 0.02 & 0.04 & 0.08 & 0.02 & 0.04 & 0.01 \\
\hline RbtTbaco & 0.04 & 0.02 & 0.02 & 0.06 & 0.08 & 0.02 & 0.02 & 0.02 \\
\hline PrrBluet & 0.06 & 0.04 & 0.02 & 0.08 & 0.10 & 0.04 & 0.02 & 0.02 \\
\hline PrCnflwr & 0.10 & 0.08 & 0.03 & 0.12 & 0.12 & 0.08 & 0.04 & 0.00 \\
\hline TxSage & 0.04 & 0.04 & 0.02 & 0.06 & 0.08 & 0.02 & 0.04 & 0.02 \\
\hline DoveWeed & 0.06 & 0.04 & 0.02 & 0.08 & 0.10 & 0.04 & 0.04 & 0.02 \\
\hline NIHckbry & 0.00 & 0.00 & 0.30 & 0.00 & 0.00 & 0.00 & 0.00 & 0.00 \\
\hline TxPrsmmn & 0.00 & 0.00 & 0.50 & 0.00 & 0.00 & 0.00 & 0.00 & 0.00 \\
\hline AsheJunp & 0.00 & 0.00 & 0.40 & 0.00 & 0.00 & 0.00 & 0.00 & 0.00 \\
\hline ShRdOak & 0.00 & 0.00 & 0.40 & 0.00 & 0.00 & 0.00 & 0.00 & 0.00 \\
\hline LvOak & 0.00 & 0.00 & 0.30 & 0.00 & 0.00 & 0.00 & 0.00 & 0.00 \\
\hline
\end{tabular}




\begin{tabular}{|c|c|c|c|c|c|c|c|c|}
\hline Species & NIHckbry & TxPrsmn & AsheJunp & ShRdOak & LvOak & CdrElm & Mesquite & Sotol \\
\hline CdrElm & 0.00 & 0.00 & 0.30 & 0.00 & 0.00 & 0.00 & 0.00 & 0.00 \\
\hline Mesquite & 0.00 & 0.00 & 0.40 & 0.00 & 0.00 & 0.00 & 0.00 & 0.00 \\
\hline Sotol & 0.30 & 0.30 & 0.20 & 0.00 & 0.00 & 0.00 & 0.00 & 0.00 \\
\hline EvgSumac & 0.00 & 0.10 & 0.30 & 0.00 & 0.00 & 0.00 & 0.00 & 0.00 \\
\hline GrnBriar & 0.00 & 0.00 & 0.10 & 0.00 & 0.00 & 0.00 & 0.10 & 0.10 \\
\hline MtnGrape & 0.00 & 0.00 & 0.00 & 0.00 & 0.00 & 0.00 & 0.00 & 0.00 \\
\hline AnnIGrs & 0.06 & 0.04 & 0.04 & 0.00 & 0.00 & 0.00 & 0.08 & 0.06 \\
\hline OfThrAn & 0.12 & 0.20 & 0.08 & 0.00 & 0.00 & 0.04 & 0.20 & 0.16 \\
\hline KRBluStm & 0.12 & 0.16 & 0.08 & 0.00 & 0.00 & 0.00 & 0.12 & 0.10 \\
\hline SiBluStm & 0.08 & 0.12 & 0.08 & 0.00 & 0.00 & 0.00 & 0.00 & 0.00 \\
\hline SdOtsGrm & 0.08 & 0.00 & 0.08 & 0.00 & 0.00 & 0.00 & 0.02 & 0.00 \\
\hline HryGrm & 0.16 & 0.24 & 0.08 & 0.00 & 0.00 & 0.08 & 0.24 & 0.20 \\
\hline BrmdaGrs & 0.16 & 0.24 & 0.08 & 0.00 & 0.00 & 0.08 & 0.24 & 0.20 \\
\hline TxCupGrs & 0.06 & 0.04 & 0.04 & 0.00 & 0.00 & 0.00 & 0.08 & 0.06 \\
\hline SpMuhly & 0.08 & 0.16 & 0.04 & 0.00 & 0.00 & 0.02 & 0.08 & 0.06 \\
\hline LIBluStm & 0.04 & 0.04 & 0.06 & 0.00 & 0.00 & 0.00 & 0.00 & 0.00 \\
\hline IndnGrs & 0.10 & 0.04 & 0.06 & 0.00 & 0.00 & 0.00 & 0.00 & 0.00 \\
\hline TIDrpSd & 0.08 & 0.04 & 0.04 & 0.00 & 0.00 & 0.00 & 0.00 & 0.00 \\
\hline TxWntGrs & 0.04 & 0.04 & 0.00 & 0.00 & 0.00 & 0.02 & 0.06 & 0.04 \\
\hline CrlyMsqt & 0.16 & 0.24 & 0.08 & 0.00 & 0.00 & 0.08 & 0.24 & 0.20 \\
\hline BrmWd & 0.12 & 0.08 & 0.08 & 0.00 & 0.00 & 0.00 & 0.20 & 0.16 \\
\hline WdSedge & 0.08 & 0.16 & 0.04 & 0.00 & 0.00 & 0.02 & 0.10 & 0.08 \\
\hline RbtTbaco & 0.08 & 0.08 & 0.06 & 0.00 & 0.00 & 0.08 & 0.20 & 0.16 \\
\hline PrrBluet & 0.10 & 0.08 & 0.06 & 0.00 & 0.00 & 0.04 & 0.12 & 0.08 \\
\hline PrCnflwr & 0.12 & 0.04 & 0.08 & 0.00 & 0.00 & 0.00 & 0.08 & 0.04 \\
\hline TxSage & 0.08 & 0.24 & 0.08 & 0.00 & 0.00 & 0.08 & 0.12 & 0.10 \\
\hline DoveWeed & 0.10 & 0.08 & 0.06 & 0.00 & 0.00 & 0.04 & 0.12 & 0.08 \\
\hline NIHckbry & 0.00 & 0.00 & 0.00 & 0.00 & 0.00 & 0.00 & 0.00 & 0.00 \\
\hline TxPrsmmn & 0.00 & 0.00 & 0.00 & 0.00 & 0.00 & 0.00 & 0.00 & 0.00 \\
\hline AsheJunp & 0.00 & 0.00 & 0.00 & 0.00 & 0.00 & 0.00 & 0.00 & 0.00 \\
\hline ShRdOak & 0.00 & 0.00 & 0.00 & 0.00 & 0.00 & 0.00 & 0.00 & 0.00 \\
\hline LvOak & 0.00 & 0.00 & 0.00 & 0.00 & 0.00 & 0.00 & 0.00 & 0.00 \\
\hline CdrElm & 0.00 & 0.00 & 0.00 & 0.00 & 0.00 & 0.00 & 0.00 & 0.00 \\
\hline Mesquite & 0.00 & 0.00 & 0.00 & 0.00 & 0.00 & 0.00 & 0.00 & 0.00 \\
\hline Sotol & 0.00 & 0.00 & 0.00 & 0.00 & 0.20 & 0.30 & 0.15 & 0.00 \\
\hline EvgSumac & 0.00 & 0.00 & 0.00 & 0.00 & 0.00 & 0.00 & 0.00 & 0.00 \\
\hline GrnBriar & 0.00 & 0.00 & 0.00 & 0.00 & 0.20 & 0.30 & 0.10 & 0.00 \\
\hline
\end{tabular}




\begin{tabular}{|c|c|c|c|c|c|c|c|c|}
\hline Species & NIHckbry & TxPrsmn & AsheJunp & ShRdOak & LvOak & CdrElm & Mesquite & Soto \\
\hline MtnGrape & 0.00 & 0.00 & 0.00 & 0.00 & 0.00 & 0.00 & 0.00 & 0.00 \\
\hline AnnlGrs & 0.00 & 0.00 & 0.00 & 0.00 & 0.12 & 0.16 & 0.08 & 0.00 \\
\hline OfThrAn & 0.00 & 0.00 & 0.08 & 0.04 & 0.22 & 0.24 & 0.20 & 0.00 \\
\hline KRBluStm & 0.00 & 0.00 & 0.02 & 0.00 & 0.05 & 0.16 & 0.12 & 0.00 \\
\hline SiBluStm & 0.00 & 0.00 & 0.00 & 0.00 & 0.02 & 0.04 & 0.00 & 0.00 \\
\hline SdOtsGrm & 0.00 & 0.00 & 0.00 & 0.00 & 0.04 & 0.08 & 0.00 & 0.00 \\
\hline HryGrm & 0.00 & 0.00 & 0.12 & 0.04 & 0.28 & 0.32 & 0.26 & 0.08 \\
\hline BrmdaGrs & 0.00 & 0.00 & 0.12 & 0.04 & 0.28 & 0.32 & 0.26 & 0.08 \\
\hline TxCupGrs & 0.00 & 0.00 & 0.00 & 0.00 & 0.12 & 0.16 & 0.08 & 0.00 \\
\hline SpMuhly & 0.00 & 0.00 & 0.02 & 0.00 & 0.10 & 0.12 & 0.08 & 0.00 \\
\hline LIBluStm & 0.00 & 0.00 & 0.00 & 0.00 & 0.00 & 0.04 & 0.00 & 0.00 \\
\hline IndnGrs & 0.00 & 0.00 & 0.00 & 0.00 & 0.00 & 0.00 & 0.00 & 0.00 \\
\hline TIDrpSd & 0.00 & 0.00 & 0.00 & 0.00 & 0.04 & 0.12 & 0.00 & 0.00 \\
\hline TxWntGrs & 0.00 & 0.00 & 0.00 & 0.00 & 0.02 & 0.08 & 0.06 & 0.00 \\
\hline CrlyMsqt & 0.00 & 0.00 & 0.12 & 0.04 & 0.28 & 0.32 & 0.26 & 0.08 \\
\hline BrmWd & 0.00 & 0.00 & 0.00 & 0.00 & 0.24 & 0.28 & 0.16 & 0.00 \\
\hline WdSedge & 0.00 & 0.00 & 0.04 & 0.04 & 0.12 & 0.16 & 0.06 & 0.00 \\
\hline RbtTbaco & 0.00 & 0.00 & 0.08 & 0.08 & 0.28 & 0.32 & 0.16 & 0.08 \\
\hline PrrBluet & 0.00 & 0.00 & 0.04 & 0.00 & 0.24 & 0.28 & 0.08 & 0.00 \\
\hline PrCnflwr & 0.00 & 0.00 & 0.00 & 0.00 & 0.05 & 0.20 & 0.04 & 0.00 \\
\hline TxSage & 0.00 & 0.00 & 0.12 & 0.04 & 0.20 & 0.24 & 0.16 & 0.04 \\
\hline DoveWeed & 0.00 & 0.00 & 0.04 & 0.00 & 0.24 & 0.28 & 0.08 & 0.00 \\
\hline NIHckbry & 0.00 & 0.00 & 0.00 & 0.00 & 0.00 & 0.00 & 0.00 & 0.00 \\
\hline TxPrsmmn & 0.00 & 0.00 & 0.00 & 0.00 & 0.00 & 0.00 & 0.00 & 0.00 \\
\hline AsheJunp & 0.00 & 0.00 & 0.00 & 0.00 & 0.00 & 0.00 & 0.00 & 0.00 \\
\hline ShRdOak & 0.00 & 0.00 & 0.00 & 0.00 & 0.00 & 0.00 & 0.00 & 0.00 \\
\hline LvOak & 0.00 & 0.00 & 0.00 & 0.00 & 0.00 & 0.00 & 0.00 & 0.00 \\
\hline CdrElm & 0.00 & 0.00 & 0.00 & 0.00 & 0.00 & 0.00 & 0.00 & 0.00 \\
\hline Mesquite & 0.00 & 0.00 & 0.00 & 0.00 & 0.00 & 0.00 & 0.00 & 0.00 \\
\hline Sotol & 0.00 & 0.00 & 0.00 & 0.00 & 0.00 & 0.00 & 0.00 & 0.00 \\
\hline EvgSumac & 0.00 & 0.00 & 0.00 & 0.00 & 0.00 & 0.00 & 0.00 & 0.00 \\
\hline GrnBriar & 0.00 & 0.00 & 0.00 & 0.00 & 0.00 & 0.00 & 0.00 & 0.00 \\
\hline MtnGrape & 0.00 & 0.00 & 0.00 & 0.00 & 0.00 & 0.00 & 0.00 & 0.00 \\
\hline AnnIGrs & 0.00 & 0.00 & 0.00 & 0.00 & 0.00 & 0.00 & 0.00 & 0.00 \\
\hline OfThrAn & 0.00 & 0.12 & 0.00 & 0.00 & 0.00 & 0.04 & 0.00 & 0.00 \\
\hline KRBluStm & 0.00 & 0.04 & 0.00 & 0.00 & 0.00 & 0.02 & 0.00 & 0.00 \\
\hline SiBluStm & 0.00 & 0.00 & 0.00 & 0.00 & 0.00 & 0.00 & 0.00 & 0.00 \\
\hline SdOtsGrm & 0.00 & 0.00 & 0.00 & 0.00 & 0.00 & 0.00 & 0.00 & 0.00 \\
\hline
\end{tabular}




\begin{tabular}{|l|l|l|l|l|l|l|l|l|}
\hline Species & NIHckbry & TxPrsmn & AsheJunp & ShRdOak & LvOak & CdrElm & Mesquite & Sotol \\
\hline HryGrm & 0.00 & 0.12 & 0.00 & 0.02 & 0.04 & 0.08 & 0.04 & 0.04 \\
\hline BrmdaGrs & 0.00 & 0.12 & 0.00 & 0.02 & 0.04 & 0.08 & 0.04 & 0.04 \\
\hline TxCupGrs & 0.00 & 0.00 & 0.00 & 0.00 & 0.00 & 0.00 & 0.00 & 0.00 \\
\hline SpMuhly & 0.00 & 0.02 & 0.00 & 0.00 & 0.00 & 0.02 & 0.00 & 0.00 \\
\hline LIBluStm & 0.00 & 0.00 & 0.00 & 0.00 & 0.00 & 0.00 & 0.00 & 0.00 \\
\hline IndnGrs & 0.00 & 0.00 & 0.00 & 0.00 & 0.00 & 0.00 & 0.00 & 0.00 \\
\hline TIDrpSd & 0.00 & 0.00 & 0.00 & 0.00 & 0.00 & 0.00 & 0.00 & 0.00 \\
\hline TxWntGrs & 0.00 & 0.02 & 0.00 & 0.00 & 0.00 & 0.00 & 0.00 & 0.00 \\
\hline CrlyMsqt & 0.00 & 0.12 & 0.00 & 0.02 & 0.04 & 0.08 & 0.04 & 0.04 \\
\hline BrmWd & 0.00 & 0.00 & 0.00 & 0.00 & 0.00 & 0.08 & 0.00 & 0.00 \\
\hline WdSedge & 0.00 & 0.02 & 0.00 & 0.00 & 0.00 & 0.02 & 0.00 & 0.00 \\
\hline RbtTbaco & 0.00 & 0.12 & 0.00 & 0.00 & 0.04 & 0.16 & 0.04 & 0.04 \\
\hline PrrBluet & 0.00 & 0.04 & 0.00 & 0.00 & 0.00 & 0.08 & 0.00 & 0.00 \\
\hline PrCnflwr & 0.00 & 0.00 & 0.00 & 0.00 & 0.00 & 0.00 & 0.00 & 0.00 \\
\hline TxSage & 0.00 & 0.08 & 0.00 & 0.00 & 0.00 & 0.08 & 0.00 & 0.00 \\
\hline DoveWeed & 0.00 & 0.04 & 0.00 & 0.00 & 0.00 & 0.08 & 0.00 & 0.00 \\
\hline
\end{tabular}

Note: Light competition factor is a suppressing effect factor on potential growth of one species (columns) on another (rows). 
Table B18. Physiological controls.

\begin{tabular}{|c|c|c|c|c|}
\hline Species & $\begin{array}{l}\text { Growing Season } \\
\text { Maximum Root:shoot }\end{array}$ & $\begin{array}{l}\text { Growing Season Green-out } \\
\text { Maximum Root:shoot }\end{array}$ & $\begin{array}{l}\text { Maximum 1-month } \\
\text { Seed Germination }\end{array}$ & $\begin{array}{l}\text { Maximum 1st month } \\
\text { Seedling Growth }\end{array}$ \\
\hline NIHckbry & 0.90 & 0.58 & 0.80 & 15 \\
\hline TxPrsmmn & 1.00 & 0.51 & 0.70 & 9 \\
\hline AsheJunp & 1.00 & 0.43 & 0.36 & 10 \\
\hline ShRdOak & 1.30 & 0.38 & 0.90 & 9 \\
\hline LvOak & 1.20 & 0.41 & 0.95 & 8 \\
\hline CdrElm & 0.70 & 0.68 & 0.70 & 15 \\
\hline Mesquite & 1.80 & 0.28 & 0.75 & 15 \\
\hline Sotol & 5.40 & 0.09 & 0.75 & 15 \\
\hline EvgSumac & 5.10 & 0.10 & 0.48 & 20 \\
\hline GrnBriar & 2.00 & 0.25 & 0.60 & 30 \\
\hline MtnGrape & 5.10 & 0.10 & 0.96 & 20 \\
\hline AnnIGrs & 1.20 & 0.41 & 0.50 & 30 \\
\hline OfThrAn & 1.40 & 0.35 & 0.90 & 40 \\
\hline KRBluStm & 3.00 & 0.17 & 0.70 & 30 \\
\hline SiBluStm & 2.40 & 0.21 & 0.55 & 30 \\
\hline SdOtsGrm & 1.90 & 0.26 & 0.66 & 30 \\
\hline HryGrm & 4.70 & 0.11 & 0.39 & 30 \\
\hline BrmdaGrs & 2.90 & 0.27 & 0.82 & 30 \\
\hline TxCupGrs & 1.20 & 0.41 & 0.50 & 30 \\
\hline SpMuhly & 2.50 & 0.20 & 0.12 & 30 \\
\hline LIBluStm & 2.40 & 0.21 & 0.53 & 30 \\
\hline IndnGrs & 3.30 & 0.15 & 0.56 & 30 \\
\hline TIDrpSd & 3.40 & 0.15 & 0.80 & 40 \\
\hline TxWntGrs & 2.50 & 0.20 & 0.13 & 30 \\
\hline CrlyMsqt & 4.70 & 0.11 & 0.62 & 30 \\
\hline BrmWd & 0.90 & 0.56 & 0.95 & 30 \\
\hline WdSedge & 3.50 & 0.15 & 0.35 & 30 \\
\hline RbtTbaco & 3.90 & 0.13 & 0.50 & 40 \\
\hline \begin{tabular}{|l|} 
PrrBluet \\
\end{tabular} & 3.90 & 0.13 & 0.60 & 30 \\
\hline PrCnflwr & 3.90 & 0.13 & 0.99 & 30 \\
\hline TxSage & 3.00 & 0.17 & 0.44 & 40 \\
\hline DoveWeed & 0.70 & 0.27 & 0.70 & 50 \\
\hline
\end{tabular}

Note: Growing season maximum root:shoot is the maximum root to shoot ratio allowed during the growing season.

Growing season green-out maximum root:shoot is the maximum root to shoot ratio allowed during green-out months.

Maximum 1-month seed germination is the maximum proportion of seed bank seeds that can germinate in any one month.

Maximum $1^{\text {st }}$ month seedling growth is the maximum factor increase in biomass for seedlings after germination. 
Table B19. End of growing season dieback.

\begin{tabular}{|c|c|c|c|c|c|c|}
\hline Species & CRoot & FRoot & Trunk & Stems & Leaves & Seeds \\
\hline NIHckbry & 0.01 & 0.05 & 0.01 & 0.05 & 1.00 & 1.00 \\
\hline TxPrsmmn & 0.01 & 0.05 & 0.01 & 0.03 & 0.90 & 1.00 \\
\hline AsheJunp & 0.01 & 0.10 & 0.01 & 0.03 & 0.33 & 1.00 \\
\hline ShRdOak & 0.01 & 0.05 & 0.01 & 0.01 & 1.00 & 1.00 \\
\hline LvOak & 0.01 & 0.05 & 0.01 & 0.01 & 0.50 & 1.00 \\
\hline CdrElm & 0.01 & 0.05 & 0.02 & 0.03 & 1.00 & 1.00 \\
\hline Mesquite & 0.01 & 0.05 & 0.01 & 0.03 & 1.00 & 1.00 \\
\hline Sotol & 0.05 & 0.15 & 0.05 & 0.10 & 0.33 & 1.00 \\
\hline EvgSumac & 0.03 & 0.10 & 0.02 & 0.20 & 0.50 & 1.00 \\
\hline GrnBriar & 0.05 & 0.20 & 0.10 & 0.20 & 1.00 & 1.00 \\
\hline MtnGrape & 0.02 & 0.10 & 0.03 & 0.20 & 1.00 & 1.00 \\
\hline AnnIGrs & 1.00 & 1.00 & 1.00 & 1.00 & 1.00 & 1.00 \\
\hline OfThrAn & 1.00 & 1.00 & 1.00 & 1.00 & 1.00 & 1.00 \\
\hline KRBluStm & 0.10 & 0.20 & 0.05 & 0.60 & 0.95 & 1.00 \\
\hline SiBluStm & 0.08 & 0.20 & 0.05 & 1.00 & 1.00 & 1.00 \\
\hline SdOtsGrm & 0.08 & 0.20 & 0.05 & 1.00 & 1.00 & 1.00 \\
\hline HryGrm & 0.10 & 0.20 & 0.10 & 1.00 & 1.00 & 1.00 \\
\hline BrmdaGrs & 0.10 & 0.20 & 0.05 & 0.60 & 1.00 & 1.00 \\
\hline TxCupGrs & 0.10 & 0.20 & 0.10 & 1.00 & 1.00 & 1.00 \\
\hline SpMuhly & 0.10 & 0.20 & 0.10 & 1.00 & 1.00 & 1.00 \\
\hline LIBluStm & 0.08 & 0.20 & 0.05 & 1.00 & 1.00 & 1.00 \\
\hline IndnGrs & 0.06 & 0.20 & 0.05 & 0.95 & 1.00 & 1.00 \\
\hline TIDrpSd & 0.08 & 0.20 & 0.05 & 1.00 & 1.00 & 1.00 \\
\hline TxWntGrs & 0.10 & 0.20 & 0.08 & 1.00 & 1.00 & 1.00 \\
\hline CrlyMsqt & 0.06 & 0.20 & 0.03 & 0.30 & 1.00 & 1.00 \\
\hline BrmWd & 1.00 & 1.00 & 1.00 & 1.00 & 1.00 & 1.00 \\
\hline WdSedge & 0.10 & 0.20 & 0.10 & 1.00 & 1.00 & 1.00 \\
\hline RbtTbaco & 1.00 & 1.00 & 1.00 & 1.00 & 1.00 & 1.00 \\
\hline PrrBluet & 0.20 & 0.40 & 0.15 & 1.00 & 1.00 & 1.00 \\
\hline PrCnflwr & 0.20 & 0.40 & 0.20 & 1.00 & 1.00 & 1.00 \\
\hline TxSage & 0.20 & 0.25 & 0.20 & 1.00 & 1.00 & 1.00 \\
\hline DoveWeed & 0.50 & 0.60 & 0.50 & 0.90 & 0.90 & 1.00 \\
\hline
\end{tabular}

Note: End of growing season dieback is the proportion of each plant component that dies at winter dormancy. 
Table B20. Dieback fate.

\begin{tabular}{|c|c|c|c|c|c|c|}
\hline Species & CRoot & FRoot & Trunk & Stems & Leaves & Seeds \\
\hline NIHckbry & -1 & -1 & 7 & 7 & 0 & 0 \\
\hline TxPrsmmn & -1 & -1 & 7 & 7 & 0 & 0 \\
\hline AsheJunp & -1 & -1 & 7 & 7 & 0 & 0 \\
\hline ShRdOak & -1 & -1 & 7 & 7 & 0 & 0 \\
\hline LvOak & -1 & -1 & 7 & 7 & 0 & 0 \\
\hline CdrElm & -1 & -1 & 7 & 7 & 0 & 0 \\
\hline Mesquite & -1 & -1 & 7 & 7 & 0 & 0 \\
\hline Sotol & -1 & -1 & 7 & 7 & 8 & 0 \\
\hline EvgSumac & -1 & -1 & 7 & 7 & 0 & 0 \\
\hline GrnBriar & -1 & -1 & 0 & 7 & 0 & 0 \\
\hline MtnGrape & -1 & -1 & 7 & 7 & 0 & 0 \\
\hline AnnIGrs & -1 & -1 & 0 & 7 & 8 & 0 \\
\hline OfThrAn & -1 & -1 & 0 & 7 & 8 & 0 \\
\hline KRBIuStm & -1 & -1 & 0 & 0 & 8 & 0 \\
\hline SiBluStm & -1 & -1 & 0 & 7 & 8 & 0 \\
\hline SdOtsGrm & -1 & -1 & 0 & 7 & 8 & 0 \\
\hline HryGrm & -1 & -1 & 0 & 7 & 8 & 0 \\
\hline BrmdaGrs & -1 & -1 & 0 & 0 & 8 & 0 \\
\hline TxCupGrs & -1 & -1 & 0 & 7 & 8 & 0 \\
\hline SpMuhly & -1 & -1 & 0 & 7 & 8 & 0 \\
\hline LIBluStm & -1 & -1 & 0 & 7 & 8 & 0 \\
\hline IndnGrs & -1 & -1 & 0 & 7 & 8 & 0 \\
\hline TIDrpSd & -1 & -1 & 0 & 7 & 8 & 0 \\
\hline TxWntGrs & -1 & -1 & 0 & 7 & 8 & 0 \\
\hline CrlyMsqt & -1 & -1 & 0 & 0 & 8 & 0 \\
\hline BrmWd & -1 & -1 & 7 & 7 & 8 & 0 \\
\hline WdSedge & -1 & -1 & 0 & 7 & 8 & 0 \\
\hline RbtTbaco & -1 & -1 & 0 & 7 & 8 & 0 \\
\hline PrrBluet & -1 & -1 & 0 & 7 & 8 & 0 \\
\hline PrCnflwr & -1 & -1 & 7 & 7 & 8 & 0 \\
\hline TxSage & -1 & -1 & 0 & 7 & 0 & 0 \\
\hline DoveWeed & -1 & -1 & 0 & 7 & 8 & 0 \\
\hline
\end{tabular}

Note: Dieback fate indicates where dieback biomass is transferred.
-1 organic matter in the soil profile
0 surface litter
7 standing dead stems
8 standing dead leaves 
Table B21. Fuel loads.

\begin{tabular}{|c|c|c|c|c|c|c|c|c|c|c|c|}
\hline Species & CRoot & FRoot & Trunk & Stems & \begin{tabular}{|l|} 
Leaves \\
\end{tabular} & Seeds & SDStems & SDLeaves & SdlgRoot & SdlgShoot & SeedBank \\
\hline NIHckbry & 0.00 & 0.00 & 0.25 & 0.50 & 1.00 & 1.00 & 0.75 & 1.50 & 0.00 & 1.00 & 1.00 \\
\hline TxPrsmmn & 0.00 & 0.00 & 0.30 & 0.50 & 1.00 & 1.00 & 0.75 & 1.50 & 0.00 & 1.00 & 1.00 \\
\hline AsheJunp & 0.00 & 0.00 & 0.50 & 0.75 & 2.00 & 1.00 & 1.00 & 4.00 & 0.00 & 2.00 & 1.00 \\
\hline ShRdOak & 0.00 & 0.00 & 0.25 & 0.50 & 1.00 & 0.75 & 0.75 & 1.50 & 0.00 & 1.00 & 0.90 \\
\hline LvOak & 0.00 & 0.00 & 0.25 & 0.50 & 1.00 & 0.75 & 0.75 & 1.50 & 0.00 & 1.00 & 0.90 \\
\hline CdrElm & 0.00 & 0.00 & 0.25 & 0.50 & 1.00 & 1.00 & 0.75 & 1.50 & 0.00 & 1.00 & 1.00 \\
\hline Mesquite & 0.00 & 0.00 & 0.10 & 0.20 & 0.80 & 0.60 & 0.80 & 1.00 & 0.00 & 0.80 & 0.80 \\
\hline Sotol & 0.00 & 0.00 & 0.25 & 0.50 & 0.75 & 1.00 & 1.00 & 1.50 & 0.00 & 0.75 & 1.00 \\
\hline EvgSumac & 0.00 & 0.00 & 0.50 & 0.80 & 1.00 & 1.00 & 1.00 & 1.50 & 0.00 & 1.00 & 1.00 \\
\hline GrnBriar & 0.00 & 0.00 & 0.00 & 0.80 & 0.90 & 1.00 & 1.00 & 1.50 & 0.00 & 1.00 & 1.00 \\
\hline MtnGrape & 0.00 & 0.00 & 0.50 & 1.00 & 1.00 & 1.00 & 1.50 & 1.00 & 0.00 & 1.00 & 1.00 \\
\hline AnnlGrs & 0.00 & 0.00 & 0.00 & 1.00 & 1.00 & 1.00 & 1.50 & 1.50 & 0.00 & 1.00 & 1.00 \\
\hline OfThrAn & 0.00 & 0.00 & 0.40 & 1.00 & 1.00 & 1.00 & 1.50 & 1.50 & 0.00 & 1.00 & 1.00 \\
\hline KRBluStm & 0.00 & 0.00 & 0.00 & 1.00 & 1.00 & 1.00 & 1.50 & 1.50 & 0.00 & 1.00 & 1.00 \\
\hline SiBluStm & 0.00 & 0.00 & 0.00 & 1.00 & 1.00 & 1.00 & 1.50 & 1.50 & 0.00 & 1.00 & 1.00 \\
\hline SdOtsGrm & 0.00 & 0.00 & 0.00 & 1.00 & 1.00 & 1.00 & 1.50 & 1.50 & 0.00 & 1.00 & 1.00 \\
\hline HryGrm & 0.00 & 0.00 & 0.00 & 1.00 & 1.00 & 1.00 & 1.50 & 1.50 & 0.00 & 1.00 & 1.00 \\
\hline BrmdaGrs & 0.00 & 0.00 & 0.00 & 1.00 & 1.00 & 1.00 & 1.50 & 1.50 & 0.00 & 1.00 & 1.00 \\
\hline TxCupGrs & 0.00 & 0.00 & 0.00 & 1.00 & 1.00 & 1.00 & 1.50 & 1.50 & 0.00 & 1.00 & 1.00 \\
\hline SpMuhly & 0.00 & 0.00 & 0.00 & 1.00 & 1.00 & 1.00 & 1.50 & 1.50 & 0.00 & 1.00 & 1.00 \\
\hline LIBluStm & 0.00 & 0.00 & 0.00 & 1.00 & 1.00 & 1.00 & 1.50 & 1.50 & 0.00 & 1.00 & 1.00 \\
\hline IndnGrs & 0.00 & 0.00 & 0.00 & 1.00 & 1.00 & 1.00 & 1.50 & 1.50 & 0.00 & 1.00 & 1.00 \\
\hline TIDrpSd & 0.00 & 0.00 & 0.00 & 1.00 & 1.00 & 1.00 & 1.50 & 1.50 & 0.00 & 1.00 & 1.00 \\
\hline TxWntGrs & 0.00 & 0.00 & 0.00 & 1.00 & 1.00 & 1.00 & 1.50 & 1.50 & 0.00 & 1.00 & 1.00 \\
\hline CrlyMsqt & 0.00 & 0.00 & 0.00 & 1.00 & 1.00 & 1.00 & 1.50 & 1.50 & 0.00 & 1.00 & 1.00 \\
\hline BrmWd & 0.00 & 0.00 & 0.00 & 1.00 & 1.50 & 1.00 & 1.50 & 2.00 & 0.00 & 1.00 & 1.00 \\
\hline WdSedge & 0.00 & 0.00 & 0.00 & 0.90 & 1.00 & 1.00 & 1.50 & 1.50 & 0.00 & 1.00 & 1.00 \\
\hline RbtTbaco & 0.00 & 0.00 & 0.00 & 1.00 & 1.00 & 1.00 & 1.50 & 1.50 & 0.00 & 1.00 & 1.00 \\
\hline PrrBluet & 0.00 & 0.00 & 0.00 & 1.00 & 1.00 & 1.00 & 1.50 & 1.50 & 0.00 & 1.00 & 1.00 \\
\hline PrCnflwr & 0.00 & 0.00 & 0.00 & 1.00 & 1.00 & 1.00 & 1.50 & 1.50 & 0.00 & 1.00 & 1.00 \\
\hline TxSage & 0.00 & 0.00 & 0.00 & 1.00 & 1.10 & 1.00 & 1.50 & 1.50 & 0.00 & 1.00 & 1.00 \\
\hline DoveWeed & 0.00 & 0.00 & 0.00 & 1.00 & 1.00 & 1.00 & 1.00 & 1.00 & 0.00 & 1.00 & 1.00 \\
\hline
\end{tabular}

Note: Fuel load is the relative contribution adjustment for each plant component biomass to total fuel loads. 
Table B22. Plant component loss to fire.

\begin{tabular}{|c|c|c|c|c|c|c|c|c|c|c|c|}
\hline Species & CRoot & FRoot & Trunk & Stems & Leaves & Seeds & SDStems & SDLeaves & SdlgRoot & SdlgShoot & SeedBank \\
\hline NIHckbry & 0.00 & 0.00 & 0.01 & 0.05 & 0.05 & 0.00 & 0.05 & 0.05 & 0.00 & 1.00 & 0.50 \\
\hline TxPrsmmn & 0.00 & 0.00 & 0.02 & 0.10 & 0.10 & 0.03 & 0.10 & 0.10 & 0.00 & 1.00 & 0.50 \\
\hline AsheJunp & 0.00 & 0.00 & 0.01 & 0.05 & 0.20 & 0.05 & 0.35 & 0.40 & 0.00 & 1.00 & 0.50 \\
\hline ShRdOak & 0.00 & 0.00 & 0.01 & 0.05 & 0.05 & 0.00 & 0.05 & 0.05 & 0.00 & 1.00 & 0.90 \\
\hline LvOak & 0.00 & 0.00 & 0.01 & 0.05 & 0.10 & 0.00 & 0.10 & 0.10 & 0.00 & 1.00 & 0.95 \\
\hline CdrElm & 0.00 & 0.00 & 0.01 & 0.05 & 0.05 & 0.00 & 0.05 & 0.05 & 0.00 & 1.00 & 0.50 \\
\hline Mesquite & 0.00 & 0.00 & 0.01 & 0.05 & 0.10 & 0.01 & 0.10 & 0.20 & 0.00 & 1.00 & 0.25 \\
\hline Sotol & 0.00 & 0.00 & 0.40 & 0.50 & 0.80 & 0.50 & 1.00 & 1.00 & 0.00 & 0.90 & 0.50 \\
\hline EvgSumac & 0.00 & 0.00 & 0.60 & 0.40 & 0.50 & 0.40 & 0.80 & 0.90 & 0.00 & 1.00 & 0.50 \\
\hline GrnBriar & 0.00 & 0.00 & 0.50 & 0.50 & 0.50 & 0.80 & 0.80 & 0.50 & 0.00 & 1.00 & 0.40 \\
\hline MtnGrape & 0.00 & 0.00 & 0.05 & 0.00 & 0.00 & 0.00 & 0.20 & 0.10 & 0.00 & 1.00 & 0.50 \\
\hline AnnIGrs & 0.00 & 0.00 & 0.40 & 0.90 & 1.00 & 1.00 & 1.00 & 1.00 & 0.00 & 1.00 & 0.50 \\
\hline OfThrAn & 0.00 & 0.00 & 0.50 & 1.00 & 1.00 & 1.00 & 1.00 & 1.00 & 0.00 & 1.00 & 0.50 \\
\hline KRBluStm & 0.00 & 0.00 & 0.30 & 0.90 & 1.00 & 1.00 & 1.00 & 1.00 & 0.00 & 1.00 & 0.50 \\
\hline SiBluStm & 0.00 & 0.00 & 0.40 & 1.00 & 1.00 & 1.00 & 1.00 & 1.00 & 0.00 & 1.00 & 0.50 \\
\hline SdOtsGrm & 0.05 & 0.00 & 0.30 & 1.00 & 1.00 & 1.00 & 1.00 & 1.00 & 0.00 & 1.00 & 0.50 \\
\hline HryGrm & 0.00 & 0.00 & 0.40 & 1.00 & 1.00 & 1.00 & 1.00 & 1.00 & 0.00 & 1.00 & 0.50 \\
\hline BrmdaGrs & 0.00 & 0.00 & 0.15 & 1.00 & 1.00 & 1.00 & 1.00 & 1.00 & 0.00 & 1.00 & 0.40 \\
\hline TxCupGrs & 0.00 & 0.00 & 0.40 & 0.90 & 1.00 & 1.00 & 1.00 & 1.00 & 0.00 & 1.00 & 0.50 \\
\hline SpMuhly & 0.00 & 0.00 & 0.40 & 0.95 & 1.00 & 1.00 & 1.00 & 1.00 & 0.00 & 1.00 & 0.50 \\
\hline LIBluStm & 0.00 & 0.00 & 0.30 & 0.95 & 1.00 & 1.00 & 1.00 & 1.00 & 0.00 & 1.00 & 0.50 \\
\hline IndnGrs & 0.00 & 0.00 & 0.30 & 0.90 & 1.00 & 1.00 & 1.00 & 1.00 & 0.00 & 1.00 & 0.50 \\
\hline TIDrpSd & 0.00 & 0.00 & 0.30 & 1.00 & 1.00 & 1.00 & 1.00 & 1.00 & 0.00 & 1.00 & 0.30 \\
\hline TxWntGrs & 0.00 & 0.00 & 0.30 & 1.00 & 1.00 & 1.00 & 1.00 & 1.00 & 0.00 & 1.00 & 0.40 \\
\hline CrlyMsqt & 0.00 & 0.00 & 0.15 & 1.00 & 1.00 & 1.00 & 1.00 & 1.00 & 0.00 & 1.00 & 0.40 \\
\hline BrmWd & 0.00 & 0.00 & 0.80 & 1.00 & 1.00 & 1.00 & 1.00 & 1.00 & 0.00 & 1.00 & 0.30 \\
\hline WdSedge & 0.00 & 0.00 & 0.30 & 0.90 & 0.90 & 1.00 & 1.00 & 1.00 & 0.00 & 0.90 & 0.50 \\
\hline RbtTbaco & 0.00 & 0.00 & 0.70 & 1.00 & 1.00 & 1.00 & 1.00 & 1.00 & 0.00 & 1.00 & 0.50 \\
\hline PrrBluet & 0.00 & 0.00 & 0.40 & 1.00 & 1.00 & 1.00 & 1.00 & 1.00 & 0.00 & 1.00 & 0.40 \\
\hline PrCnflwr & 0.00 & 0.00 & 0.90 & 1.00 & 1.00 & 1.00 & 1.00 & 1.00 & 0.00 & 1.00 & 0.40 \\
\hline TxSage & 0.00 & 0.00 & 0.60 & 1.00 & 1.00 & 1.00 & 1.00 & 1.00 & 0.00 & 1.00 & 0.50 \\
\hline DoveWeed & 0.00 & 0.00 & 0.80 & 1.00 & 1.00 & 1.00 & 1.00 & 1.00 & 0.00 & 1.00 & 0.60 \\
\hline
\end{tabular}

Note: Plant component loss to fire is the proportion of component biomass lost to moderate fires. 
Table B23. Insect preference and competition matrix.

\begin{tabular}{|c|c|c|c|c|c|c|c|c|c|c|c|}
\hline Species & CRoot & FRoot & Trunk & Stems & Leaves & Seeds & SDStems & SDLeaves & SdlgRoot & SdlgShoot & SeedBank \\
\hline NIHckbry & 0,0 & 0,0 & 0,1 & 0,1 & 1,1 & 10,1 & 0,1 & 13,1 & 0,1 & 1,1 & 0,1 \\
\hline TxPrsmmn & 0,0 & 0,0 & 0,1 & 0,1 & 5,1 & 6,1 & 0,1 & 0,1 & 0,1 & 4,1 & 0,1 \\
\hline AsheJunp & 0,0 & 0,0 & 0,0 & 0,1 & 12,1 & 11,1 & 0,1 & 0,1 & 0,0 & 11,1 & 0,1 \\
\hline ShRdOak & 0,0 & 0,0 & 0,1 & 0,1 & 3,1 & 0,1 & 0,1 & 0,1 & 0,1 & 3,1 & 0,1 \\
\hline LvOak & 0,0 & 0,0 & 0,1 & 0,1 & 10,1 & 0,1 & 0,1 & 0,1 & 0,1 & 9,1 & 0,1 \\
\hline CdrElm & 0,0 & 0,0 & 0,1 & 0,1 & 1,1 & 10,1 & 0,1 & 13,1 & 0,1 & 1,1 & 0,1 \\
\hline Mesquite & 0,0 & 0,0 & 0,0 & 0,0 & 12,1 & 11,1 & 0,0 & 13,1 & 0,0 & 12,1 & 0,0 \\
\hline Sotol & 0,0 & 0,0 & 11,1 & 11,1 & 10,1 & 3,1 & 0,1 & 0,1 & 0,1 & 10,1 & 0,1 \\
\hline EvgSumac & 0,0 & 0,0 & 0,0 & 0,1 & 4,1 & 4,1 & 0,1 & 0,1 & 0,1 & 3,1 & 0,1 \\
\hline GrnBriar & 0,0 & 0,0 & 0,0 & 13,1 & 8,1 & 5,1 & 0,1 & 0,1 & 0,1 & 7,1 & 0,1 \\
\hline MtnGrape & 0,0 & 0,0 & 0,0 & 0,1 & 1,1 & 1,1 & 0,1 & 13,1 & 0,1 & 1,1 & 0,1 \\
\hline AnnlGrs & 0,0 & 0,0 & 7,1 & 4,1 & 1,1 & 4,1 & 0,1 & 13,1 & 0,1 & 1,1 & 0,1 \\
\hline OfThrAn & 0,0 & 0,0 & 9,1 & 7,1 & 6,1 & 8,1 & 0,1 & 13,1 & 0,1 & 4,1 & 0,1 \\
\hline KRBIuStm & 0,0 & 0,0 & 7,1 & 4,1 & 1,1 & 4,1 & 0,1 & 13,1 & 0,1 & 1,1 & 0,1 \\
\hline SiBluStm & 0,0 & 0,0 & 8,1 & 4,1 & 1,1 & 4,1 & 0,1 & 13,1 & 0,1 & 1,1 & 0,1 \\
\hline SdOtsGrm & 0,0 & 0,0 & 8,1 & 4,1 & 1,1 & 4,1 & 0,1 & 13,1 & 0,1 & 1,1 & 0,1 \\
\hline HryGrm & 0,0 & 0,0 & 8,1 & 5,1 & 5,1 & 5,1 & 0,1 & 13,1 & 0,1 & 3,1 & 0,1 \\
\hline BrmdaGrs & 0,0 & 0,0 & 6,1 & 6,1 & 3,1 & 4,1 & 11,1 & 7,1 & 0,0 & 2,1 & 0,0 \\
\hline TxCupGrs & 0,0 & 0,0 & 7,1 & 4,1 & 1,1 & 4,1 & 0,1 & 13,1 & 0,1 & 1,1 & 0,1 \\
\hline SpMuhly & 0,0 & 0,0 & 7,1 & 4,1 & 4,1 & 4,1 & 0,1 & 13,1 & 0,1 & 2,1 & 0,1 \\
\hline LIBluStm & 0,0 & 0,0 & 8,1 & 7,1 & 1,1 & 6,1 & 0,1 & 13,1 & 0,1 & 1,1 & 0,1 \\
\hline IndnGrs & 0,0 & 0,0 & 8,1 & 7,1 & 1,1 & 3,1 & 0,1 & 13,1 & 0,1 & 1,1 & 0,1 \\
\hline TIDrpSd & 0,0 & 0,0 & 8,1 & 5,1 & 4,1 & 5,1 & 0,1 & 13,1 & 0,1 & 3,1 & 0,1 \\
\hline TxWntGrs & 0,0 & 0,0 & 7,1 & 5,1 & 4,1 & 5,1 & 0,1 & 13,1 & 0,1 & 2,1 & 0,1 \\
\hline CrlyMsqt & 0,0 & 0,0 & 6,1 & 6,1 & 3,1 & 4,1 & 11,1 & 7,1 & 0,0 & 2,1 & 0,0 \\
\hline BrmWd & 0,0 & 0,0 & 12,1 & 8,1 & 7,1 & 6,1 & 0,1 & 0,1 & 0,1 & 6,1 & 0,1 \\
\hline WdSedge & 0,0 & 0,0 & 8,1 & 4,1 & 1,1 & 4,1 & 0,1 & 13,1 & 0,1 & 1,1 & 0,1 \\
\hline RbtTbaco & 0,0 & 0,0 & 7,1 & 4,1 & 2,1 & 2,1 & 0,1 & 13,1 & 0,1 & 1,1 & 0,1 \\
\hline PrrBluet & 0,0 & 0,0 & 8,1 & 4,1 & 2,1 & 2,1 & 0,1 & 13,1 & 0,1 & 1,1 & 0,1 \\
\hline PrCnflwr & 0,0 & 0,0 & 9,1 & 4,1 & 2,1 & 1,1 & 0,1 & 0,1 & 0,1 & 1,1 & 0,1 \\
\hline TxSage & 0,0 & 0,0 & 9,1 & 4,1 & 2,1 & 3,1 & 0,1 & 13,1 & 0,1 & 1,1 & 0,1 \\
\hline DoveWeed & 0,2 & 0,2 & 3,1 & 2,1 & 1,1 & 2,1 & 4,1 & 2,1 & 0,3 & 1,1 & 0,2 \\
\hline
\end{tabular}

Note: Preference is insect diet preference ranking for each plant component for each species, while competition is the relative competitive ability of insects in obtaining the plant component for each species. 
Table B24. Insect accessibility matrix.

\begin{tabular}{|c|c|c|c|c|c|c|c|c|c|c|c|}
\hline Species & CRoot & FRoot & Trunk & Stems & Leaves & Seeds & SDStems & SDLeaves & SdlgRoot & SdlgShoot & SeedBank \\
\hline NIHckbry & 0 & 0 & 0 & 50 & 100 & 100 & 50 & 100 & 0 & 100 & 5 \\
\hline TxPrsmmn & 0 & 0 & 0 & 50 & 100 & 100 & 50 & 100 & 0 & 100 & 20 \\
\hline AsheJunp & 0 & 0 & 0 & 50 & 100 & 100 & 50 & 100 & 0 & 100 & 10 \\
\hline ShRdOak & 0 & 0 & 0 & 50 & 100 & 100 & 50 & 100 & 0 & 100 & 90 \\
\hline LvOak & 0 & 0 & 0 & 50 & 100 & 100 & 50 & 100 & 0 & 100 & 90 \\
\hline CdrElm & 0 & 0 & 0 & 50 & 100 & 100 & 50 & 100 & 0 & 100 & 50 \\
\hline Mesquite & 0 & 0 & 80 & 100 & 100 & 100 & 100 & 100 & 0 & 100 & 50 \\
\hline Sotol & 0 & 0 & 50 & 75 & 100 & 100 & 75 & 100 & 0 & 100 & 10 \\
\hline EvgSumac & 0 & 0 & 10 & 50 & 100 & 100 & 50 & 100 & 0 & 100 & 10 \\
\hline GrnBriar & 0 & 0 & 100 & 100 & 100 & 100 & 100 & 100 & 0 & 100 & 5 \\
\hline MtnGrape & 0 & 0 & 100 & 40 & 100 & 100 & 40 & 100 & 0 & 100 & 10 \\
\hline AnnlGrs & 0 & 0 & 60 & 100 & 100 & 100 & 100 & 100 & 0 & 100 & 10 \\
\hline OfThrAn & 0 & 0 & 60 & 100 & 100 & 100 & 100 & 100 & 0 & 100 & 5 \\
\hline KRBluStm & 0 & 0 & 60 & 90 & 100 & 100 & 100 & 100 & 0 & 100 & 10 \\
\hline SiBluStm & 0 & 0 & 40 & 100 & 100 & 100 & 100 & 100 & 0 & 100 & 10 \\
\hline SdOtsGrm & 0 & 0 & 40 & 100 & 100 & 100 & 100 & 100 & 0 & 100 & 10 \\
\hline HryGrm & 0 & 0 & 60 & 100 & 100 & 100 & 100 & 100 & 0 & 100 & 10 \\
\hline BrmdaGrs & 0 & 0 & 60 & 90 & 100 & 100 & 100 & 100 & 0 & 100 & 10 \\
\hline TxCupGrs & 0 & 0 & 60 & 100 & 100 & 100 & 100 & 100 & 0 & 100 & 10 \\
\hline SpMuhly & 0 & 0 & 60 & 100 & 100 & 100 & 100 & 100 & 0 & 100 & 5 \\
\hline LIBluStm & 0 & 0 & 40 & 90 & 90 & 90 & 90 & 90 & 0 & 90 & 10 \\
\hline IndnGrs & 0 & 0 & 40 & 100 & 100 & 100 & 100 & 100 & 0 & 100 & 10 \\
\hline TIDrpSd & 0 & 0 & 40 & 100 & 100 & 100 & 100 & 100 & 0 & 100 & 5 \\
\hline TxWntGrs & 0 & 0 & 40 & 100 & 100 & 100 & 100 & 100 & 0 & 100 & 5 \\
\hline CrlyMsqt & 0 & 0 & 60 & 90 & 100 & 100 & 100 & 100 & 0 & 100 & 10 \\
\hline BrmWd & 0 & 0 & 90 & 90 & 90 & 90 & 90 & 90 & 0 & 90 & 0 \\
\hline WdSedge & 0 & 0 & 60 & 90 & 90 & 90 & 90 & 90 & 0 & 90 & 5 \\
\hline RbtTbaco & 0 & 0 & 90 & 90 & 90 & 90 & 90 & 90 & 0 & 90 & 0 \\
\hline PrrBluet & 0 & 0 & 90 & 90 & 90 & 90 & 90 & 90 & 0 & 90 & 0 \\
\hline PrCnflwr & 0 & 0 & 90 & 90 & 90 & 90 & 90 & 90 & 0 & 90 & 0 \\
\hline TxSage & 0 & 0 & 90 & 90 & 90 & 90 & 90 & 90 & 0 & 90 & 0 \\
\hline DoveWeed & 0 & 0 & 50 & 100 & 100 & 100 & 100 & 100 & 0 & 100 & 30 \\
\hline
\end{tabular}

Note: Accessibility is the proportion of the total component biomass that is accessible for consumption by insects. 
Table B25. Rabbit preference and competition matrix.

\begin{tabular}{|c|c|c|c|c|c|c|c|c|c|c|c|}
\hline Species & CRoot & FRoot & Trunk & Stems & Leaves & Seeds & SDStems & SDLeaves & SdlgRoot & SdlgShoot & SeedBank \\
\hline NIHckbry & 0,0 & 0,0 & 12,2 & 8,4 & 4,4 & 7,4 & 0,0 & 9,4 & 0,0 & 1,2 & 8,2 \\
\hline TxPrsmmn & 0,0 & 0,0 & 13,2 & 9,4 & 6,4 & 5,4 & 0,0 & 10,4 & 0,0 & 5,2 & 6,2 \\
\hline AsheJunp & 0,0 & 0,0 & 0,0 & 15,4 & 14,4 & 15,4 & 0,0 & 16,4 & 0,0 & 12,2 & 15,2 \\
\hline ShRdOak & 0,0 & 0,0 & 0,0 & 10,4 & 7,4 & 6,4 & 0,0 & 11,4 & 0,0 & 5,2 & 6,2 \\
\hline LvOak & 0,0 & 0,0 & 0,0 & 14,4 & 8,4 & 6,4 & 0,0 & 12,4 & 0,0 & 6,2 & 6,2 \\
\hline CdrElm & 0,0 & 0,0 & 12,2 & 8,4 & 4,4 & 7,4 & 0,0 & 9,4 & 0,0 & 2,2 & 7,2 \\
\hline Mesquite & 0,0 & 0,0 & 19,2 & 17,2 & 16,2 & 7,2 & 0,0 & 18,2 & 0,0 & 15,2 & 11,2 \\
\hline Sotol & 0,0 & 0,0 & 8,2 & 8,4 & 7,2 & 2,4 & 0,0 & 0,0 & 0,0 & 6,2 & 0,0 \\
\hline EvgSumac & 0,0 & 0,0 & 13,2 & 9,4 & 7,4 & 6,4 & 0,0 & 10,4 & 0,0 & 6,2 & 0,0 \\
\hline GrnBriar & 0,0 & 0,0 & 11,2 & 7,2 & 6,2 & 7,3 & 14,2 & 8,2 & 0,0 & 5,2 & 0,0 \\
\hline MtnGrape & 0,0 & 0,0 & 0,0 & 8,4 & 4,4 & 2,4 & 0,0 & 9,4 & 0,0 & 1,2 & 0,0 \\
\hline AnnIGrs & 0,0 & 0,0 & 4,2 & 3,2 & 2,2 & 2,2 & 9,2 & 4,2 & 0,0 & 1,2 & 0,0 \\
\hline OfThrAn & 0,0 & 0,0 & 7,2 & 6,2 & 5,2 & 6,2 & 0,0 & 8,2 & 0,0 & 4,2 & 0,0 \\
\hline KRBluStm & 0,0 & 0,0 & 4,2 & 4,2 & 3,2 & 3,2 & 9,2 & 5,2 & 0,0 & 2,2 & 0,0 \\
\hline SiBluStm & 0,0 & 0,0 & 5,2 & 4,2 & 3,2 & 4,2 & 10,2 & 5,2 & 0,0 & 2,2 & 0,0 \\
\hline SdOtsGrm & 0,0 & 0,0 & 5,2 & 4,2 & 3,2 & 3,2 & 9,2 & 5,2 & 0,0 & 2,2 & 0,0 \\
\hline HryGrm & 0,0 & 0,0 & 5,2 & 4,2 & 3,2 & 4,2 & 9,2 & 6,2 & 0,0 & 2,2 & 0,0 \\
\hline BrmdaGrs & 0,0 & 0,0 & 4,2 & 4,2 & 2,2 & 2,2 & 5,2 & 3,2 & 0,0 & 2,2 & 0,0 \\
\hline TxCupGrs & 0,0 & 0,0 & 4,2 & 3,2 & 2,2 & 2,2 & 9,2 & 4,2 & 0,0 & 1,2 & 0,0 \\
\hline SpMuhly & 0,0 & 0,0 & 5,2 & 4,2 & 3,2 & 4,2 & 9,2 & 5,2 & 0,0 & 2,2 & 0,0 \\
\hline LIBluStm & 0,0 & 0,0 & 6,2 & 5,2 & 3,2 & 5,2 & 10,2 & 5,2 & 0,0 & 2,2 & 0,0 \\
\hline IndnGrs & 0,0 & 0,0 & 5,2 & 4,2 & 3,2 & 2,2 & 10,2 & 5,2 & 0,0 & 2,2 & 0,0 \\
\hline TIDrpSd & 0,0 & 0,0 & 6,2 & 5,2 & 3,2 & 5,2 & 10,2 & 5,2 & 0,0 & 2,2 & 0,0 \\
\hline TxWntGrs & 0,0 & 0,0 & 6,2 & 5,2 & 3,2 & 5,2 & 10,2 & 6,2 & 0,0 & 2,2 & 0,0 \\
\hline CrlyMsqt & 0,0 & 0,0 & 4,2 & 4,2 & 2,2 & 2,2 & 5,2 & 3,2 & 0,0 & 2,2 & 0,0 \\
\hline BrmWd & 0,0 & 0,0 & 9,2 & 7,2 & 5,2 & 3,2 & 11,2 & 8,2 & 0,0 & 4,2 & 0,0 \\
\hline WdSedge & 0,0 & 0,0 & 5,2 & 3,2 & 2,2 & 3,2 & 10,2 & 4,2 & 0,0 & 1,2 & 0,0 \\
\hline RbtTbaco & 0,0 & 0,0 & 4,2 & 2,2 & 1,2 & 2,2 & 8,2 & 4,2 & 0,0 & 1,2 & 0,0 \\
\hline PrrBluet & 0,0 & 0,0 & 6,2 & 4,2 & 1,2 & 4,2 & 9,2 & 5,2 & 0,0 & 1,2 & 0,0 \\
\hline PrCnflwr & 0,0 & 0,0 & 5,2 & 3,2 & 1,2 & 2,2 & 9,2 & 4,2 & 0,0 & 1,2 & 0,0 \\
\hline TxSage & 0,0 & 0,0 & 5,2 & 2,2 & 1,2 & 2,2 & 8,2 & 5,2 & 0,0 & 1,2 & 0,0 \\
\hline DoveWeed & 7,1 & 7,1 & 8,2 & 3,2 & 1,2 & 2,2 & 5,2 & 4,2 & 0,2 & 1,2 & 0,1 \\
\hline
\end{tabular}

Note: Preference is rabbit diet preference ranking for each plant component for each species, while competition is the relative competitive ability of rabbits in obtaining the plant component for each species. 
Table B26. Rabbit accessibility matrix.

\begin{tabular}{|c|c|c|c|c|c|c|c|c|c|c|c|}
\hline Species & CRoot & FRoot & Trunk & Stems & Leaves & Seeds & SDStems & SDLeaves & SdlgRoot & SdlgShoot & SeedBank \\
\hline NIHckbry & 5 & 0 & 5 & 1 & 2 & 1 & 1 & 1 & 0 & 100 & 5 \\
\hline TxPrsmmn & 5 & 0 & 5 & 3 & 5 & 3 & 3 & 3 & 0 & 100 & 40 \\
\hline AsheJunp & 0 & 0 & 0 & 0 & 0 & 0 & 0 & 0 & 0 & 0 & 0 \\
\hline ShRdOak & 5 & 0 & 5 & 1 & 1 & 0 & 1 & 1 & 0 & 100 & 40 \\
\hline LvOak & 0 & 0 & 0 & 0 & 0 & 0 & 0 & 0 & 0 & 0 & 0 \\
\hline CdrElm & 5 & 0 & 5 & 1 & 1 & 0 & 1 & 1 & 0 & 100 & 10 \\
\hline Mesquite & 5 & 0 & 10 & 5 & 5 & 1 & 5 & 5 & 0 & 90 & 70 \\
\hline Sotol & 5 & 0 & 100 & 100 & 100 & 100 & 100 & 100 & 0 & 100 & 5 \\
\hline EvgSumac & 5 & 0 & 20 & 25 & 30 & 0 & 25 & 30 & 0 & 100 & 2 \\
\hline GrnBriar & 5 & 0 & 100 & 50 & 50 & 30 & 50 & 50 & 0 & 100 & 0 \\
\hline MtnGrape & 5 & 0 & 2 & 0 & 0 & 0 & 0 & 0 & 0 & 100 & 5 \\
\hline AnnIGrs & 5 & 0 & 95 & 100 & 100 & 100 & 100 & 100 & 0 & 100 & 5 \\
\hline OfThrAn & 5 & 0 & 90 & 100 & 100 & 100 & 100 & 100 & 0 & 100 & 0 \\
\hline KRBluStm & 5 & 0 & 95 & 95 & 100 & 100 & 100 & 100 & 0 & 100 & 5 \\
\hline SiBluStm & 5 & 0 & 80 & 100 & 100 & 100 & 100 & 100 & 0 & 100 & 0 \\
\hline SdOtsGrm & 10 & 0 & 95 & 100 & 100 & 100 & 100 & 100 & 0 & 100 & 5 \\
\hline HryGrm & 5 & 0 & 95 & 100 & 100 & 100 & 100 & 100 & 0 & 100 & 0 \\
\hline BrmdaGrs & 5 & 0 & 95 & 95 & 100 & 100 & 100 & 100 & 0 & 100 & 5 \\
\hline TxCupGrs & 5 & 0 & 95 & 100 & 100 & 100 & 100 & 100 & 0 & 100 & 5 \\
\hline SpMuhly & 5 & 0 & 95 & 100 & 100 & 100 & 100 & 100 & 0 & 100 & 0 \\
\hline LIBluStm & 5 & 0 & 80 & 90 & 90 & 90 & 90 & 90 & 0 & 90 & 0 \\
\hline IndnGrs & 5 & 0 & 80 & 100 & 100 & 100 & 100 & 100 & 0 & 100 & 5 \\
\hline TIDrpSd & 5 & 0 & 85 & 100 & 100 & 100 & 100 & 100 & 0 & 100 & 0 \\
\hline TxWntGrs & 5 & 0 & 90 & 100 & 100 & 100 & 100 & 100 & 0 & 100 & 0 \\
\hline CrlyMsqt & 5 & 0 & 95 & 95 & 100 & 100 & 100 & 100 & 0 & 100 & 5 \\
\hline BrmWd & 5 & 0 & 90 & 90 & 90 & 90 & 90 & 90 & 0 & 90 & 0 \\
\hline WdSedge & 5 & 0 & 80 & 90 & 90 & 90 & 90 & 90 & 0 & 90 & 0 \\
\hline RbtTbaco & 5 & 0 & 90 & 90 & 90 & 90 & 90 & 90 & 0 & 90 & 0 \\
\hline PrrBluet & 5 & 0 & 95 & 90 & 90 & 90 & 90 & 90 & 0 & 90 & 0 \\
\hline PrCnflwr & 5 & 0 & 90 & 90 & 90 & 90 & 90 & 90 & 0 & 90 & 0 \\
\hline TxSage & 5 & 0 & 90 & 90 & 90 & 90 & 90 & 90 & 0 & 90 & 0 \\
\hline DoveWeed & 10 & 0 & 100 & 100 & 100 & 90 & 100 & 100 & 10 & 80 & 0 \\
\hline
\end{tabular}

Note: Accessibility is the proportion of the total component biomass that is accessible for consumption by rabbits. 
Table B27. Deer preference and competition matrix.

\begin{tabular}{|c|c|c|c|c|c|c|c|c|c|c|c|}
\hline Species & CRoot & FRoot & Trunk & Stems & Leaves & Seeds & SDStems & SDLeaves & SdlgRoot & SdlgShoot & SeedBank \\
\hline NIHckbry & 0,0 & 0,0 & 10,2 & 8,2 & 2,2 & 2,2 & 0,0 & 6,2 & 0,0 & 1,3 & 0,0 \\
\hline TxPrsmmn & 0,0 & 0,0 & 0,0 & 9,2 & 4,2 & 3,2 & 0,0 & 8,2 & 0,0 & 3,3 & 4,3 \\
\hline AsheJunp & 0,0 & 0,0 & 0,0 & 12,2 & 10,2 & 10,2 & 0,0 & 12,2 & 0,0 & 9,3 & 0,0 \\
\hline ShRdOak & 0,0 & 0,0 & 0,0 & 10,2 & 5,2 & 6,2 & 0,0 & 7,2 & 0,0 & 4,3 & 6,3 \\
\hline LvOak & 0,0 & 0,0 & 0,0 & 11,2 & 6,2 & 6,2 & 0,0 & 8,2 & 0,0 & 5,3 & 6,3 \\
\hline CdrElm & 0,0 & 0,0 & 0,0 & 9,2 & 3,2 & 3,2 & 0,0 & 6,2 & 0,0 & 3,3 & 0,0 \\
\hline Mesquite & 0,0 & 0,0 & 0,0 & 12,2 & 10,2 & 10,2 & 0,0 & 12,2 & 0,0 & 9,3 & 0,0 \\
\hline Sotol & 0,0 & 0,0 & 9,3 & 9,2 & 9,3 & 2,2 & 0,0 & 12,2 & 0,0 & 8,3 & 0,0 \\
\hline EvgSumac & 0,0 & 0,0 & 12,2 & 11,2 & 7,2 & 6,2 & 0,0 & 9,2 & 0,0 & 6,3 & 0,0 \\
\hline GrnBriar & 0,0 & 0,0 & 10,3 & 8,3 & 6,3 & 7,3 & 13,3 & 10,3 & 0,0 & 5,3 & 0,0 \\
\hline MtnGrape & 0,0 & 0,0 & 0,0 & 10,2 & 4,2 & 1,2 & 0,0 & 7,2 & 0,0 & 3,3 & 0,0 \\
\hline AnnIGrs & 0,0 & 0,0 & 5,3 & 4,3 & 4,3 & 3,3 & 5,3 & 7,3 & 0,0 & 4,3 & 0,0 \\
\hline OfThrAn & 0,0 & 0,0 & 11,3 & 9,3 & 9,3 & 9,3 & 10,3 & 9,3 & 0,0 & 9,3 & 0,0 \\
\hline KRBluStm & 0,0 & 0,0 & 6,3 & 5,3 & 4,3 & 5,3 & 6,3 & 7,3 & 0,0 & 4,3 & 0,0 \\
\hline SiBluStm & 0,0 & 0,0 & 9,3 & 8,3 & 7,3 & 8,3 & 9,3 & 8,3 & 0,0 & 7,3 & 0,0 \\
\hline SdOtsGrm & 0,0 & 0,0 & 7,3 & 6,3 & 5,3 & 5,3 & 7,3 & 7,3 & 0,0 & 5,3 & 0,0 \\
\hline HryGrm & 0,0 & 0,0 & 6,3 & 5,3 & 5,3 & 5,3 & 5,3 & 7,3 & 0,0 & 5,3 & 0,0 \\
\hline BrmdaGrs & 0,0 & 0,0 & 6,3 & 6,3 & 6,3 & 6,3 & 6,3 & 6,3 & 0,0 & 5,3 & 0,0 \\
\hline TxCupGrs & 0,0 & 0,0 & 5,3 & 4,3 & 4,3 & 3,3 & 5,3 & 7,3 & 0,0 & 4,3 & 0,0 \\
\hline SpMuhly & 0,0 & 0,0 & 7,3 & 6,3 & 6,3 & 6,3 & 7,3 & 8,3 & 0,0 & 6,3 & 0,0 \\
\hline LIBluStm & 0,0 & 0,0 & 9,3 & 8,3 & 7,3 & 8,3 & 9,3 & 8,3 & 0,0 & 7,3 & 0,0 \\
\hline IndnGrs & 0,0 & 0,0 & 8,3 & 7,3 & 6,3 & 3,3 & 8,3 & 8,3 & 0,0 & 6,3 & 0,0 \\
\hline TIDrpSd & 0,0 & 0,0 & 9,3 & 8,3 & 8,3 & 8,3 & 9,3 & 9,3 & 0,0 & 8,3 & 0,0 \\
\hline TxWntGrs & 0,0 & 0,0 & 6,3 & 5,3 & 5,3 & 5,3 & 5,3 & 8,3 & 0,0 & 5,3 & 0,0 \\
\hline CrlyMsqt & 0,0 & 0,0 & 6,3 & 6,3 & 6,3 & 6,3 & 6,3 & 6,3 & 0,0 & 5,3 & 0,0 \\
\hline BrmWd & 0,0 & 0,0 & 10,3 & 9,3 & 8,3 & 4,3 & 13,3 & 8,3 & 0,0 & 7,3 & 0,0 \\
\hline WdSedge & 0,0 & 0,0 & 5,3 & 3,3 & 3,3 & 3,3 & 5,3 & 8,3 & 0,0 & 3,3 & 0,0 \\
\hline RbtTbaco & 0,0 & 0,0 & 2,3 & 1,3 & 1,3 & 1,3 & 5,3 & 6,3 & 0,0 & 1,3 & 0,0 \\
\hline PrrBluet & 0,0 & 0,0 & 4,3 & 2,3 & 2,3 & 2,3 & 5,3 & 6,3 & 0,0 & 2,3 & 0,0 \\
\hline PrCnflwr & 0,0 & 0,0 & 3,3 & 1,3 & 1,3 & 1,3 & 7,3 & 6,3 & 0,0 & 1,3 & 0,0 \\
\hline TxSage & 0,0 & 0,0 & 2,3 & 1,3 & 1,3 & 1,3 & 5,3 & 6,3 & 0,0 & 1,3 & 0,0 \\
\hline DoveWeed & 0,0 & 0,0 & 4,3 & 2,3 & 2,3 & 2,3 & 5,3 & 6,3 & 0,0 & 2,3 & 0,0 \\
\hline
\end{tabular}

Note: Preference is deer diet preference ranking for each plant component for each species, while competition is the relative competitive ability of deer in obtaining the plant component for each species. 
Table B28. Deer accessibility matrix.

\begin{tabular}{|c|c|c|c|c|c|c|c|c|c|c|c|}
\hline Species & CRoot & FRoot & Trunk & Stems & Leaves & Seeds & SDStems & SDLeaves & SdlgRoot & SdlgShoot & SeedBank \\
\hline NIHckbry & 0 & 0 & 5 & 40 & 40 & 20 & 40 & 40 & 0 & 100 & 0 \\
\hline TxPrsmmn & 0 & 0 & 10 & 60 & 60 & 40 & 60 & 60 & 0 & 100 & 10 \\
\hline AsheJunp & 0 & 0 & 5 & 60 & 50 & 30 & 60 & 50 & 0 & 100 & 5 \\
\hline ShRdOak & 0 & 0 & 5 & 30 & 20 & 10 & 30 & 20 & 0 & 100 & 75 \\
\hline LvOak & 0 & 0 & 5 & 50 & 40 & 20 & 50 & 40 & 0 & 100 & 75 \\
\hline CdrElm & 0 & 0 & 5 & 40 & 40 & 20 & 40 & 40 & 0 & 100 & 5 \\
\hline Mesquite & 0 & 0 & 5 & 60 & 50 & 30 & 60 & 50 & 0 & 100 & 5 \\
\hline Sotol & 0 & 0 & 60 & 90 & 100 & 100 & 90 & 100 & 0 & 100 & 5 \\
\hline EvgSumac & 0 & 0 & 20 & 80 & 80 & 70 & 80 & 80 & 0 & 100 & 5 \\
\hline GrnBriar & 0 & 0 & 100 & 100 & 100 & 100 & 100 & 100 & 0 & 95 & 0 \\
\hline MtnGrape & 0 & 0 & 20 & 5 & 5 & 0 & 5 & 5 & 0 & 100 & 10 \\
\hline AnnIGrs & 0 & 0 & 80 & 100 & 100 & 100 & 100 & 100 & 0 & 90 & 5 \\
\hline OfThrAn & 0 & 0 & 90 & 100 & 100 & 100 & 100 & 100 & 0 & 90 & 0 \\
\hline KRBluStm & 0 & 0 & 80 & 80 & 95 & 100 & 80 & 95 & 0 & 90 & 0 \\
\hline SiBluStm & 0 & 0 & 70 & 100 & 100 & 100 & 100 & 100 & 0 & 90 & 0 \\
\hline SdOtsGrm & 0 & 0 & 80 & 100 & 100 & 100 & 100 & 100 & 0 & 90 & 5 \\
\hline HryGrm & 0 & 0 & 80 & 100 & 95 & 100 & 100 & 100 & 0 & 90 & 0 \\
\hline BrmdaGrs & 0 & 0 & 80 & 90 & 90 & 100 & 90 & 90 & 0 & 90 & 0 \\
\hline TxCupGrs & 0 & 0 & 80 & 100 & 100 & 100 & 100 & 100 & 0 & 90 & 5 \\
\hline SpMuhly & 0 & 0 & 70 & 100 & 100 & 100 & 100 & 100 & 0 & 90 & 0 \\
\hline LIBluStm & 0 & 0 & 70 & 90 & 90 & 90 & 90 & 90 & 0 & 90 & 0 \\
\hline IndnGrs & 0 & 0 & 65 & 100 & 100 & 100 & 100 & 100 & 0 & 90 & 5 \\
\hline TIDrpSd & 0 & 0 & 75 & 100 & 100 & 100 & 100 & 100 & 0 & 90 & 0 \\
\hline TxWntGrs & 0 & 0 & 80 & 100 & 95 & 100 & 100 & 100 & 0 & 90 & 0 \\
\hline CrlyMsqt & 0 & 0 & 80 & 90 & 90 & 100 & 90 & 90 & 0 & 90 & 0 \\
\hline BrmWd & 0 & 0 & 90 & 90 & 90 & 90 & 90 & 90 & 0 & 95 & 0 \\
\hline WdSedge & 0 & 0 & 80 & 90 & 90 & 90 & 90 & 90 & 0 & 80 & 0 \\
\hline RbtTbaco & 0 & 0 & 90 & 90 & 90 & 90 & 90 & 90 & 0 & 95 & 0 \\
\hline PrrBluet & 0 & 0 & 95 & 95 & 90 & 90 & 90 & 90 & 0 & 95 & 0 \\
\hline PrCnflwr & 0 & 0 & 90 & 90 & 90 & 90 & 90 & 90 & 0 & 95 & 0 \\
\hline TxSage & 0 & 0 & 90 & 90 & 90 & 90 & 90 & 90 & 0 & 95 & 0 \\
\hline DoveWeed & 0 & 0 & 95 & 95 & 90 & 90 & 90 & 90 & 0 & 95 & 0 \\
\hline
\end{tabular}

Note: Accessibility is the proportion of the total component biomass that is accessible for consumption by deer. 
Table B29. Cattle preference and competition matrix.

\begin{tabular}{|c|c|c|c|c|c|c|c|c|c|c|c|}
\hline Species & CRoot & FRoot & Trunk & Stems & \begin{tabular}{|l|} 
Leaves \\
\end{tabular} & Seeds & SDStems & SDLeaves & SdlgRoot & SdlgShoot & SeedBank \\
\hline NIHckbry & 0,0 & 0,0 & 0,0 & 6,3 & 6,3 & 6,3 & 0,0 & 10,3 & 0,0 & 6,4 & 0,0 \\
\hline TxPrsmmn & 0,0 & 0,0 & 13,4 & 8,3 & 8,3 & 5,3 & 0,0 & 12,3 & 0,0 & 8,4 & 0,0 \\
\hline AsheJunp & 0,0 & 0,0 & 15,4 & 14,3 & 14,3 & 14,3 & 0,0 & 15,3 & 0,0 & 14,4 & 0,0 \\
\hline ShRdOak & 0,0 & 0,0 & 0,0 & 9,3 & 9,3 & 9,3 & 0,0 & 11,3 & 0,0 & 9,4 & 0,0 \\
\hline LvOak & 0,0 & 0,0 & 0,0 & 10,3 & 10,3 & 10,3 & 0,0 & 12,3 & 0,0 & 10,4 & 0,0 \\
\hline CdrElm & 0,0 & 0,0 & 0,0 & 7,3 & 7,3 & 7,3 & 0,0 & 9,3 & 0,0 & 7,4 & 0,0 \\
\hline Mesquite & 0,0 & 0,0 & 15,4 & 14,3 & 14,3 & 14,3 & 0,0 & 15,3 & 0,0 & 14,4 & 0,0 \\
\hline Sotol & 0,0 & 0,0 & 12,4 & 12,3 & 12,4 & 7,3 & 0,0 & 15,3 & 0,0 & 12,4 & 0,0 \\
\hline EvgSumac & 0,0 & 0,0 & 0,0 & 11,3 & 11,3 & 11,3 & 0,0 & 13,3 & 0,0 & 11,4 & 0,0 \\
\hline GrnBriar & 0,0 & 0,0 & 0,0 & 10,4 & 9,4 & 10,4 & 12,4 & 12,4 & 0,0 & 9,4 & 0,0 \\
\hline MtnGrape & 0,0 & 0,0 & 0,0 & 7,3 & 7,3 & 7,3 & 0,0 & 9,3 & 0,0 & 7,4 & 0,0 \\
\hline AnnIGrs & 0,0 & 0,0 & 2,4 & 1,4 & 1,4 & 1,4 & 3,4 & 3,4 & 0,0 & 1,4 & 0,0 \\
\hline OfThrAn & 0,0 & 0,0 & 6,4 & 5,4 & 5,4 & 5,4 & 6,4 & 6,4 & 0,0 & 5,4 & 0,0 \\
\hline KRBluStm & 0,0 & 0,0 & 4,4 & 3,4 & 3,4 & 3,4 & 4,4 & 4,4 & 0,0 & 3,4 & 0,0 \\
\hline SiBluStm & 0,0 & 0,0 & 4,4 & 3,4 & 3,4 & 3,4 & 4,4 & 4,4 & 0,0 & 3,4 & 0,0 \\
\hline SdOtsGrm & 0,0 & 0,0 & 2,4 & 1,4 & 1,4 & 1,4 & 3,4 & 3,4 & 0,0 & 1,4 & 0,0 \\
\hline HryGrm & 0,0 & 0,0 & 3,4 & 2,4 & 2,4 & 2,4 & 2,4 & 2,4 & 0,0 & 2,4 & 0,0 \\
\hline BrmdaGrs & 0,0 & 0,0 & 2,4 & 1,4 & 1,4 & 1,4 & 2,4 & 2,4 & 0,0 & 1,4 & 0,0 \\
\hline TxCupGrs & 0,0 & 0,0 & 2,4 & 1,4 & 1,4 & 1,4 & 3,4 & 3,4 & 0,0 & 1,4 & 0,0 \\
\hline SpMuhly & 0,0 & 0,0 & 4,4 & 3,4 & 3,4 & 3,4 & 4,4 & 4,4 & 0,0 & 3,4 & 0,0 \\
\hline LIBluStm & 0,0 & 0,0 & 4,4 & 3,4 & 3,4 & 3,4 & 4,4 & 4,4 & 0,0 & 3,4 & 0,0 \\
\hline IndnGrs & 0,0 & 0,0 & 2,4 & 1,4 & 1,4 & 1,4 & 3,4 & 3,4 & 0,0 & 1,4 & 0,0 \\
\hline TIDrpSd & 0,0 & 0,0 & 4,4 & 3,4 & 3,4 & 3,4 & 4,4 & 4,4 & 0,0 & 3,4 & 0,0 \\
\hline TxWntGrs & 0,0 & 0,0 & 2,4 & 1,4 & 1,4 & 1,4 & 3,4 & 3,4 & 0,0 & 1,4 & 0,0 \\
\hline CrlyMsqt & 0,0 & 0,0 & 2,4 & 1,4 & 1,4 & 1,4 & 2,4 & 2,4 & 0,0 & 1,4 & 0,0 \\
\hline BrmWd & 0,0 & 0,0 & 11,4 & 10,4 & 10,4 & 9,4 & 15,4 & 15,4 & 0,0 & 9,4 & 0,0 \\
\hline WdSedge & 0,0 & 0,0 & 4,4 & 3,4 & 3,4 & 3,4 & 5,4 & 5,4 & 0,0 & 3,4 & 0,0 \\
\hline RbtTbaco & 0,0 & 0,0 & 7,4 & 6,4 & 6,4 & 6,4 & 8,4 & 8,4 & 0,0 & 6,4 & 0,0 \\
\hline PrrBluet & 0,0 & 0,0 & 6,4 & 5,4 & 5,4 & 5,4 & 7,4 & 7,4 & 0,0 & 5,4 & 0,0 \\
\hline PrCnflwr & 0,0 & 0,0 & 5,4 & 4,4 & 4,4 & 3,4 & 6,4 & 6,4 & 0,0 & 4,4 & 0,0 \\
\hline TxSage & 0,0 & 0,0 & 6,4 & 5,4 & 5,4 & 5,4 & 7,4 & 7,4 & 0,0 & 5,4 & 0,0 \\
\hline DoveWeed & 0,3 & 0,3 & 8,3 & 6,3 & 6,3 & 6,3 & 7,3 & 7,3 & 0,1 & 4,3 & 3,3 \\
\hline
\end{tabular}

Note: Preference is cattle diet preference ranking for each plant component for each species, while competition is the relative competitive ability of cattle in obtaining the plant component for each species. 
Table B30. Cattle accessibility matrix.

\begin{tabular}{|c|c|c|c|c|c|c|c|c|c|c|c|}
\hline Species & CRoot & FRoot & Trunk & Stems & Leaves & Seeds & SDStems & SDLeaves & SdlgRoot & SdlgShoot & SeedBank \\
\hline NIHckbry & 0 & 0 & 10 & 40 & 40 & 20 & 40 & 40 & 0 & 90 & 0 \\
\hline TxPrsmmn & 0 & 0 & 20 & 60 & 60 & 40 & 60 & 60 & 0 & 90 & 5 \\
\hline AsheJunp & 0 & 0 & 0 & 0 & 0 & 0 & 0 & 0 & 0 & 0 & 0 \\
\hline ShRdOak & 0 & 0 & 5 & 10 & 10 & 5 & 10 & 10 & 0 & 90 & 40 \\
\hline LvOak & 0 & 0 & 0 & 0 & 0 & 0 & 0 & 0 & 0 & 0 & 0 \\
\hline CdrElm & 0 & 0 & 10 & 10 & 10 & 5 & 10 & 10 & 0 & 90 & 0 \\
\hline Mesquite & 0 & 0 & 20 & 60 & 60 & 30 & 60 & 60 & 0 & 90 & 0 \\
\hline Sotol & 0 & 0 & 90 & 100 & 100 & 100 & 100 & 100 & 0 & 90 & 0 \\
\hline EvgSumac & 0 & 0 & 20 & 80 & 80 & 70 & 80 & 80 & 0 & 90 & 0 \\
\hline GrnBriar & 0 & 0 & 30 & 90 & 90 & 100 & 90 & 90 & 0 & 20 & 0 \\
\hline MtnGrape & 0 & 0 & 50 & 10 & 5 & 5 & 10 & 10 & 0 & 90 & 5 \\
\hline AnnlGrs & 0 & 0 & 50 & 100 & 90 & 100 & 100 & 90 & 0 & 50 & 0 \\
\hline OfThrAn & 0 & 0 & 50 & 90 & 90 & 100 & 90 & 90 & 0 & 25 & 0 \\
\hline KRBluStm & 0 & 0 & 10 & 40 & 80 & 100 & 40 & 80 & 0 & 50 & 0 \\
\hline SiBluStm & 0 & 0 & 40 & 95 & 90 & 100 & 95 & 90 & 0 & 50 & 0 \\
\hline SdOtsGrm & 0 & 0 & 50 & 90 & 90 & 100 & 90 & 90 & 0 & 50 & 0 \\
\hline HryGrm & 0 & 0 & 10 & 90 & 70 & 100 & 90 & 70 & 0 & 25 & 0 \\
\hline BrmdaGrs & 0 & 0 & 10 & 40 & 70 & 90 & 40 & 70 & 0 & 50 & 0 \\
\hline TxCupGrs & 0 & 0 & 50 & 100 & 90 & 100 & 100 & 90 & 0 & 50 & 0 \\
\hline SpMuhly & 0 & 0 & 10 & 90 & 70 & 100 & 90 & 70 & 0 & 25 & 0 \\
\hline LIBluStm & 0 & 0 & 40 & 90 & 90 & 90 & 90 & 90 & 0 & 50 & 0 \\
\hline IndnGrs & 0 & 0 & 30 & 90 & 90 & 100 & 90 & 90 & 0 & 50 & 0 \\
\hline TIDrpSd & 0 & 0 & 45 & 100 & 90 & 100 & 90 & 90 & 0 & 50 & 0 \\
\hline TxWntGrs & 0 & 0 & 30 & 90 & 70 & 100 & 90 & 70 & 0 & 50 & 0 \\
\hline CrlyMsqt & 0 & 0 & 10 & 40 & 70 & 90 & 40 & 70 & 0 & 50 & 0 \\
\hline BrmWd & 0 & 0 & 90 & 90 & 90 & 100 & 90 & 90 & 0 & 20 & 0 \\
\hline WdSedge & 0 & 0 & 10 & 90 & 60 & 90 & 90 & 60 & 0 & 20 & 0 \\
\hline RbtTbaco & 0 & 0 & 20 & 80 & 80 & 90 & 80 & 80 & 0 & 20 & 0 \\
\hline PrrBluet & 0 & 0 & 50 & 80 & 80 & 90 & 80 & 80 & 0 & 20 & 0 \\
\hline PrCnflwr & 0 & 0 & 90 & 90 & 90 & 90 & 90 & 90 & 0 & 20 & 0 \\
\hline TxSage & 0 & 0 & 90 & 90 & 90 & 90 & 90 & 90 & 0 & 20 & 0 \\
\hline DoveWeed & 0 & 0 & 70 & 90 & 90 & 90 & 90 & 90 & 0 & 50 & 0 \\
\hline
\end{tabular}

Note: Accessibility is the proportion of the total component biomass that is accessible for consumption by cattle. 


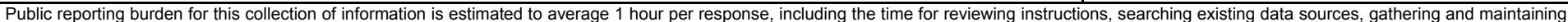

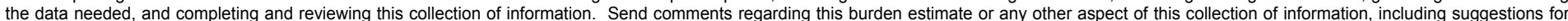

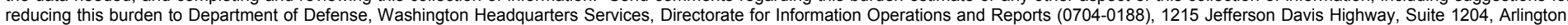

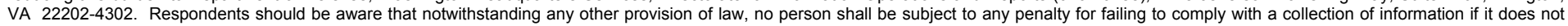
display a currently valid OMB control number. PLEASE DO NOT RETURN YOUR FORM TO THE ABOVE ADDRESS.

\begin{tabular}{l|l}
$\begin{array}{l}\text { 1. REPORT DATE (DD-MM-YYYY) } \\
\text { December } 2006\end{array}$ & $\begin{array}{c}\text { 2. REPORT TYPE } \\
\text { Final report }\end{array}$ \\
\hline
\end{tabular}

\section{TITLE AND SUBTITLE}

Linkage of a Physically Based Distributed Watershed Model and a Dynamic Plant Growth Model

3. DATES COVERED (From - To)

5a. CONTRACT NUMBER

5b. GRANT NUMBER

5c. PROGRAM ELEMENT NUMBER

5d. PROJECT NUMBER

5e. TASK NUMBER

5f. WORK UNIT NUMBER

8. PERFORMING ORGANIZATION REPORT NUMBER

ERDC/EL TR-06-17

U.S. Army Engineer Research
Environmental Laboratory

3909 Halls Ferry Road, Vicksburg, MS 39180-6199 ;

Montgomery Watson Harza, Inc.

760 Whalers Way, A-100, Fort Collins, CO 80525

9. SPONSORING / MONITORING AGENCY NAME(S) AND ADDRESS(ES)

U.S. Army Corps of Engineers

Washington, DC 20314-1000

10. SPONSOR/MONITOR'S ACRONYM(S)

11. SPONSOR/MONITOR'S REPORT NUMBER(S)

\section{DISTRIBUTION / AVAILABILITY STATEMENT}

Approved for public release; distribution is unlimited.

\section{SUPPLEMENTARY NOTES}

\section{ABSTRACT}

The impact of hydrological alteration on vegetation and of vegetation on water quality can be greatly facilitated by linking existing water engines with general ecosystem models designed to make long-term projections of ecosystem dynamics. This development effort investigated the linkage of soil moisture between the Gridded Surface Subsurface Hydrologic Analysis (GSSHA) model and the Ecological Dynamics Simulation (EDYS) model. Conceptually, the EDYS and GSSHA models are well-suited for linkage given that they are both designed to simulate physical or ecological processes at multiple spatial and temporal scales. In particular, EDYS computes small-scale flows (precipitation, interception, evaporation, infiltration, transpiration, and nutrient and contaminant uptake) on a daily basis, and can thereby provide much more accurate estimates of evapotranspiration and water, nutrient, and contaminant uptake by vegetation than would ordinarily be available for calibration of hydrologic models. GSSHA and associated groundwater codes can then provide more accurate estimates of large-scale hydrological and transport processes back to EDYS to effect a system-wide assessment or projection. The long-term objective of this linkage between EDYS and GSSHA is to collaborate with other SWWRP product lines and provide a dynamic eco-hydro modeling capability for regional applications (i.e., the Upper Mississippi, the Everglades, or the Nueces Basin).

\section{SUBJECT TERMS}

Cibola Creek Watershed

EDYS

GSSHA

Plant model

16. SECURITY CLASSIFICATION OF:

a. REPORT

UNCLASSIFIED

b. ABSTRACT
UNCLASSIFIED

c. THIS PAGE

UNCLASSIFIED
Watershed model

\begin{tabular}{l|c|}
$\begin{array}{l}\text { 17. LIMITATION } \\
\text { OF ABSTRACT }\end{array}$ & $\begin{array}{c}\text { 18. NUMBER } \\
\text { OF PAGES }\end{array}$ \\
& 103 \\
\hline
\end{tabular}

19a. NAME OF RESPONSIBLE PERSON

19b. TELEPHONE NUMBER (include area code) 